OECD Regional Development Working Papers 2016/05

Masaru Sugahara,

Leslie Bermont 


\section{OECD REGIONAL DEVELOPMENT WORKING PAPERS}

This series is designed to make available to a wider readership selected studies on regional development issues prepared for use within the OECD. Authorship is usually collective, but principal authors are named. The papers are generally available only in their original language English or French with a summary in the other if available.

OECD Working Papers should not be reported as representing the official views of the OECD or of its member countries. The opinions expressed and arguments employed are those of the author(s).

Working Papers describe preliminary results or research in progress by the author(s) and are published to stimulate discussion on a broad range of issues on which the OECD works. Comments on Working Papers are welcomed, and may be sent to either gov.contact@oecd.org or the Public Governance and Territorial Development Directorate, OECD, 2 rue André-Pascal, 75775 Paris Cedex 16, France.

Authorised for publication by Rolf Alter, Director, Public Governance and Territorial Development Directorate, OECD.

This document and any map included herein are without prejudice to the status of or sovereignty over any territory, to the delimitation of international frontiers and boundaries and to the name of any territory, city or area.

The statistical data for Israel are supplied by and under the responsibility of the relevant Israeli authorities. The use of such data by the OECD is without prejudice to the status of the Golan Heights, East Jerusalem and Israeli settlements in the West Bank under the terms of international law.

OECD Regional Development Working Papers are published on http://www.oecd.org/gov/regional/workingpapers

Applications for permission to reproduce or translate all or part of this material should be made to: OECD Publishing, rights@ oecd.org or by fax 33145249930.

(C) OECD 2016 


\title{
Energy and Resilient Cities
}

By Masaru Sugahara and Leslie Bermont.

\begin{abstract}
This paper analyses the role of cities in energy policies to build resilience and assesses related energy policy practices in cities. It analyses how energy affects resilience in cities from the economic, environmental, social and institutional perspectives. It also assesses the policy practices of six cities; Barcelona (Spain), Bristol (UK), Kyoto (Japan), Munich (Germany), Perpignan (France) and Toronto (Canada). This paper outlines the building blocks of key policy strategies; adaptive energy management, robust energy management, redundant energy management, flexible energy management, inclusive energy management, resourceful energy management and integrated energy management. It proposes a number of policy measures in the building blocks for managing energy smartly in cities to build resilience.
\end{abstract}

Keywords: cities, resilience, energy, renewables, urban development, housing and buildings

JEL Classification: Q48, Q54, R11, R58

\section{Acknowledgements}

This paper was drafted by Masaru Sugahara and Leslie Bermont. It was co-ordinated by Masaru Sugahara under the supervision of Setsuko Saya, in the Regional Policies for Sustainable Development Division of the OECD. It benefited from valuable comments and input from colleagues: Luiz de Mello, Joaquim Oliveira Martins, Karen Maguire, Rüdiger Ahrend, Hideki Takada, Tadashi Matsumoto, Abel Schumann, Johannes Weber, Christian Pollok, Loïc Daudey and participants of relevant meetings, including brownbag seminars and workshops. The OECD Secretariat wishes to thank the regional authorities and relevant organisations that co-operated on information collection of the policy practices in the case study cities. Victoria Elliott provided editorial support. The financial support of the Ministry of Land, Infrastructure, Transport and Tourism (Japan) is gratefully acknowledged. 


\section{TABLE OF CONTENTS}

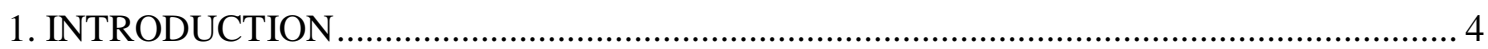

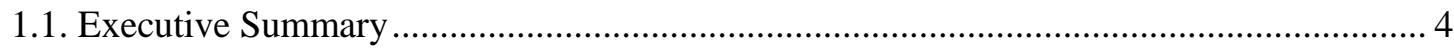

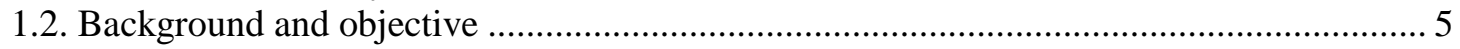

2. HOW ENERGY CAN INFLUENCE RESILIENCE IN CITIES ........................................ 11

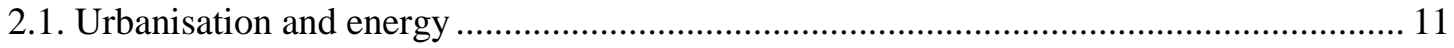

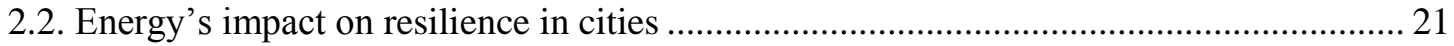

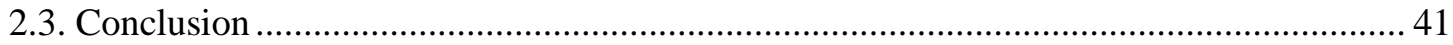

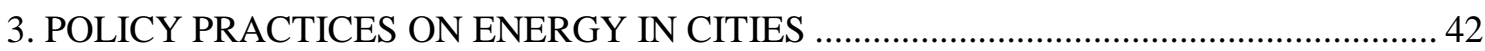

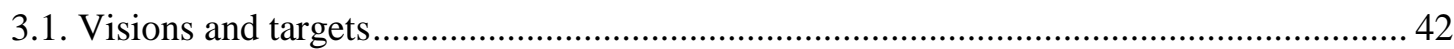

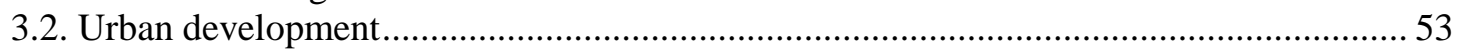

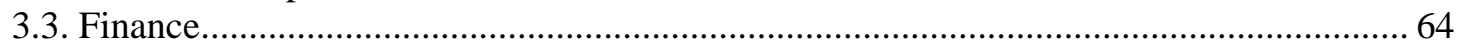

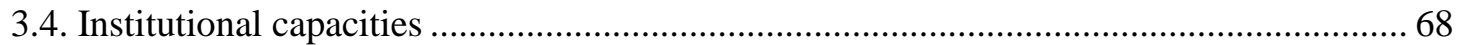

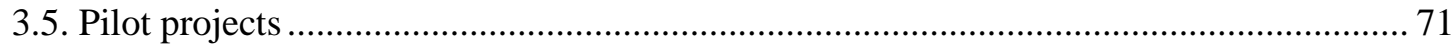



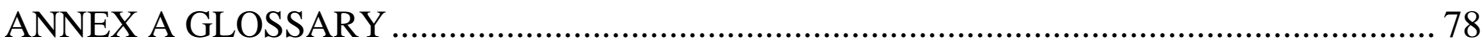

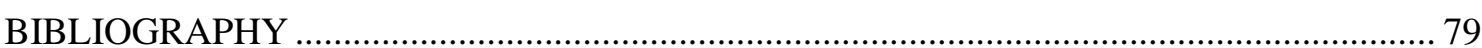

\section{Tables}

Table 1. Cities selected for information collection............................................................

Table 2. Share of local renewable energy production in total energy consumption

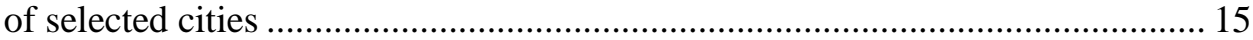

Table 3. Estimated technical potential of solar energy generation (US) .......................... 16

Table 4. Energy consumption and local renewable energy production in selected cities . 18

Table 5. The impact of energy on resilience in cities ....................................................... 21

Table 6. Disruptions of energy supply by disasters and accidents .................................. 34

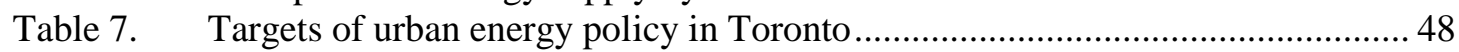

Table 8. National policy frameworks on resilience in selected countries ......................... 51

Table 9. Targets of urban energy policy in selected cities, national governments

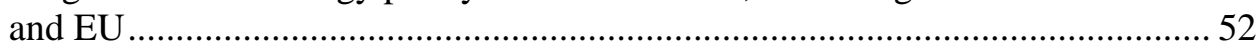

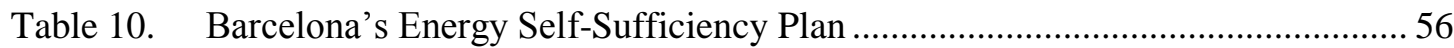

Table 11. Regulatory requirements for solar panels by subnational governments

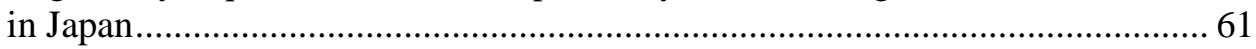

Table 12. Financing methods for energy efficiency projects ...............................................6 64

Table 13. Finance schemes for urban energy management by governments .......................67 67

Table 14. Key policy strategies of energy management for building resilience in cities .... 75 


\section{Figures}

Figure 1. Energy-related CO2 emissions in selected regions (2014) ................................. 6

Figure 2. Estimated energy demand in cities .................................................................. 11

Figure 3. Urban population share and total final consumption of energy per capita ........... 12

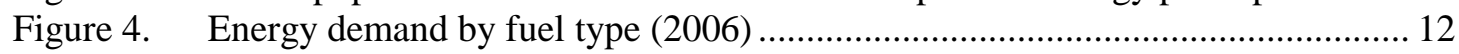

Figure 5. GDP growth and energy production growth in OECD...................................... 14

Figure 6. Energy production by energy sources in OECD ............................................... 14

Figure 7. Deployment of renewable energy facilities per unit of energy consumption

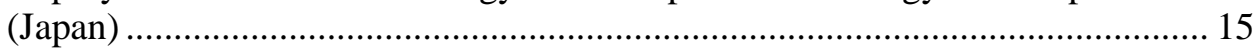

Figure 8. Energy dependency of OECD countries (2013) ……....................................... 22

Figure 9. Growth in consumer prices: energy and non-energy items ............................... 23

Figure 10. Inability to keep household sufficiently warm (2014) .................................. 25

Figure 11. GHG emissions by human activities ............................................................. 27

Figure 12. Urban population share and GHG emissions per capita (2010) ...................... 28

Figure 13. GHG emissions in the OECD AI, Baseline, 2010-2050............................. 28

Figure 14. Population density and CO2 emissions per capita in large metropolitan areas 29

Figure 15. Mean annual temperature in Tokyo, New York, Paris and Berlin, and global mean annual temperature anomaly on the ground............................... 30

Figure 16. Exposure of population to PM2.5 in the 275 OECD metropolitan areas ........ 31

Figure 17. Number of annual disasters and economic damage due to natural disasters

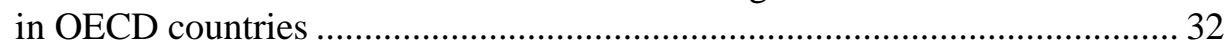

Figure 18. Blackout-initiating events, US (\% of all events from 1984 to 2006) ............... 32

Figure 19. Blackout initiating events and mean size in customers, US (1984-2006) ........ 33

Figure 20. Choices of the structure for operations and planning of energy network......... 39

Figure 21. Renewable energy plants of SWM in Munich, Germany and Europe ............ 45

Figure 22. Targets of urban energy policy in Kyoto.......................................................... 47

Figure 23. Final energy consumption by sector in OECD countries (Mtoe) ..................... 53

Figure 24. Breakdown of final energy consumption in Other sector in Figure 23

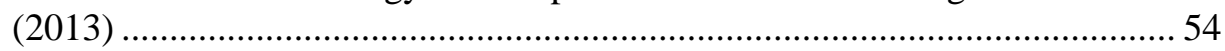

Figure 25. Existing District Energy Systems and Potential for New Systems in

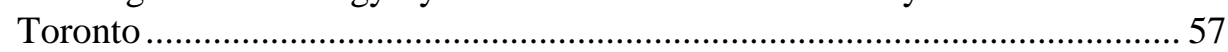

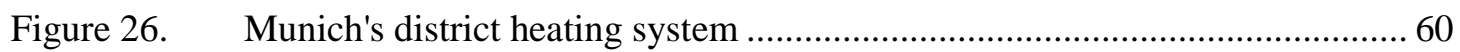

Figure 27. GHG emissions by sector in Perpignan (2012) ................................................ 61

Figure 28. Breakdown of final energy consumption in the transport sector in OECD

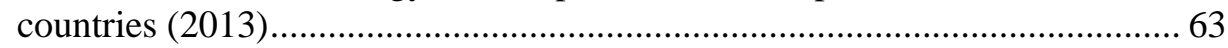

Figure 29. Energy consumption per unit by transport mode, Japan, 2009 ........................ 63

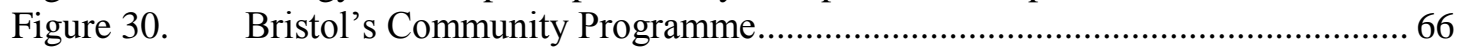

\section{Boxes}

Box 1. The drivers and building blocks of a resilient city .................................................... 7

Box 2. Monitoring energy and $\mathrm{CO}_{2}$ emissions - The ECORegion software .......................... 17

Box 3. Disruptions of the energy supply in the Great East Japan Earthquake ......................... 35

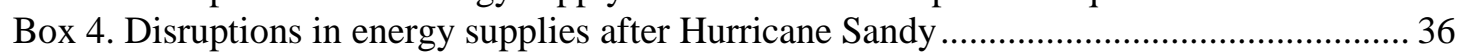

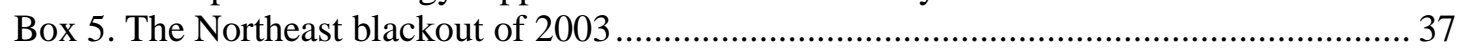

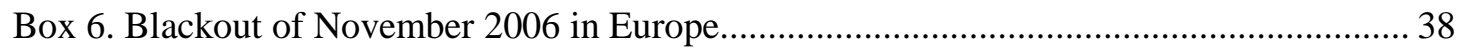

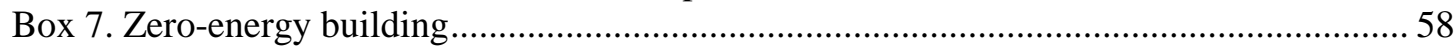

Box 8. Energy management systems in housing, building and cities .................................... 71 


\section{INTRODUCTION}

\subsection{Executive summary}

This report analyses the role of cities in energy policies to build resilience and assesses related energy policy practices in cities. It explores how cities can best manage their energy needs and supply, and summarises key policy strategies. Cities are the base for economic activity and generate the preponderance of growth in OECD countries: metropolitan areas with more than 500000 inhabitants account for more than half of gross domestic product (GDP) in OECD countries. Cities also play a significant role in situations of stress, and have different approaches to risk management.

Energy is a crucial element in building resilience in cities. The level and type of energy cities use affect the economy, the environment and the well-being not only of their citizens but also that of residents elsewhere. Cities mainly depend on fossil fuels currently, and it amplifies the energy's impacts on economy, environment and society. From an economic perspective, cities' demand for energy is steadily increasing, and fluctuations in energy prices make the daily life of citizens as well as industrial activity unstable. From an environmental standpoint, cities now depend principally on fossil fuels, and they both cause and suffer from their negative environmental effects, including emissions of greenhouse gases (GHG), heat and air pollution. From a social perspective, any disruption of the energy supply can affect large numbers of the population, as well as production through supply chains. These issues will be more serious because the energy consumption in cities is expected to continue to increase as the urban population increases.

Two approaches are proposed to overcome those challenges. First is enhancing the cities' energy management to improve energy efficiency and to reduce energy consumption. Second is decreasing the dependence on fossil fuel by deploying renewable energy in cities. Urban policies to meet these objectives will be more significant considering the further urbanisation in the OECD countries.

Cities can enhance their economic performance by planning and implementing energy policy, including visions and targets, urban development, finance, institutional capacities and pilot projects. However, cities have different institutional settings depending on energy demand and supply, including regulation, the division of responsibilities between national and local governments, financial incentives (subsidies and tax), existing energy infrastructure, players in the energy market and the energy resources currently available. Therefore, energy policies in cities need to be place-based, and no single methodology can be adapted to all cities.

Energy management in cities requires key policy strategies to maximizing potential of cities by mobilizing various assets including physical environment, institution and finance in cities. The seven key strategies are; adaptive energy management, robust energy management, redundant energy management, flexible energy management, resourceful energy management, inclusive energy management and integrated energy management. Cities' success in energy policy can contribute to the well-being of urban residents, and to achieving national energy policy objectives and national growth. National governments as well as sub-national governments thus have a significant role to play in establishing and implementing energy policies in cities.

Adaptive energy management aims to manage uncertainty in energy demand and supply in cities. Mainstreaming energy management in urban policy is the key for achieving this objective. This requires a long-term vision for energy management, and a cross-cutting and comprehensive approach to urban policy. Measuring energy data at the city level helps cities evaluate the current state of resources, set targets and analyse the impact of policy. 
Robust energy management involves a city's ability to absorb stresses and emerge from them without significant losses to its capacity to function. Improving energy infrastructure can be achieved through appropriate maintenance, effective disaster risk management and updating to reduce damages in crises Developing energy self-sufficient housing, buildings and urban blocks is one option for helping stabilise the energy supply in emergency situations.

Redundant energy management helps cities to meet the need for extra capacity when faced with unexpected demand, a disruptive event or unusual pressures. Diversity in energy management, including sources, methods and source areas, can equip cities to better deal with it. Finance schemes for smart energy management need to be effective to encourage investment from a variety of sources. For example, "green bonds" for energy efficiency and green infrastructure are issued by some sub-national governments, as was the case recently in the province of Ontario in Canada.

Flexible energy management is to help individuals, households, businesses, communities and government adjust their behaviour to respond to changes in energy demand and supply in cities. A long-term vision, with a mid-term strategic implementation plan, is important to allow for modifying the plan as necessary to meet any challenges in future. Pilot projects can contribute to this by identifying a problem, checking the feasibility of any action taken and predicting its effects in advance.

Resourceful energy management is to help an urban system restore essential services and systems effectively and quickly in a crisis. Increasing renewable energy production in cities can enhance local energy supply in a crisis. Enhancing the energy efficiency of housing and buildings can also lower energy demand, which eases pressure on the energy supply in a crisis and contributes to the objective. Urban and energy policies need to be well co-ordinated, because the physical environment influences energy demand, energy efficiency and the potential of renewable energy production. Effective urban transport policies, including high-efficiency transport and co-ordination of urban development and urban transport planning, are also vital.

Inclusive energy management can help ensure that diverse actors are fully engaged and empowered in the policy process. Collaboration between industries, academia and governments can help governments keep up to date with the latest technological advances and approaches. Governments should seek out the relevant stakeholders, including regulators, and better co-ordinate between them. Raising awareness of energy efficiency among citizens can enlist the help of citizens in their daily lives, and encourage participation in the policy.

Integrated energy management can help promote a co-operative and collaborative approach to policy and programming to better ensure coherent decisions and effective investment. Creating alliances between cities contributes to knowledge sharing and lobbying.

\subsection{Background and objective}

Cities are the basis of economic activity and their citizens' daily life. They are critical drivers of national growth. A small fraction of OECD regions, as little as $2 \%$, mainly the largest urban areas, generate one-third of the growth in the OECD as a whole (OECD, 2013). The global urban population is projected to be on a continuous upward trend, reaching approximately 6.3 billion by 2050 and accounting for $66 \%$ of aggregate population (UN, 2014). As the world continues to urbanise, and urban areas continue to grow, so will exposure to shock and crisis. Cities are expected to play a significant role in such events, given their importance within national economies. Some cities, however, appear less vulnerable and better able to withstand destabilising shocks and long-term chronic pressures. Resilience is an important attribute that helps explain why some cities can absorb, recover, adapt to and be prepared for the past and future impact of economic, environmental, social and institutional shocks or chronic pressure (Box 1), while others cannot (OECD, 2015a). Resilience will help cities to promote sustainable development, well-being and inclusive growth. 
Energy (ANNEX A) is one of the crucial elements in building resilience in cities, because it is indispensable in sustaining large populations, diverse urban functions, industry and the overall economic growth of cities. The level and type of energy use in cities has an impact not only on the economic, environment and well-being of urban citizens, but also on residents elsewhere. Energy consumption is a cause of greenhouse gas emissions, and approximately $71 \%$ of global energy-related emissions of carbon dioxide (Figure 1) are caused by energy use in cities (IEA, 2008). In addition, interruptions of the energy supply result in substantial increases in energy costs and can lead to costly disruption of services (OECD, 2007), with potentially wider regional or global effects through supply chains. As the increase in urban energy demand and supply affects the economy, society and the environment, managing energy well will remain a vital factor in cities' resilience.

Figure 1. Energy-related CO2 emissions in selected regions (2014)

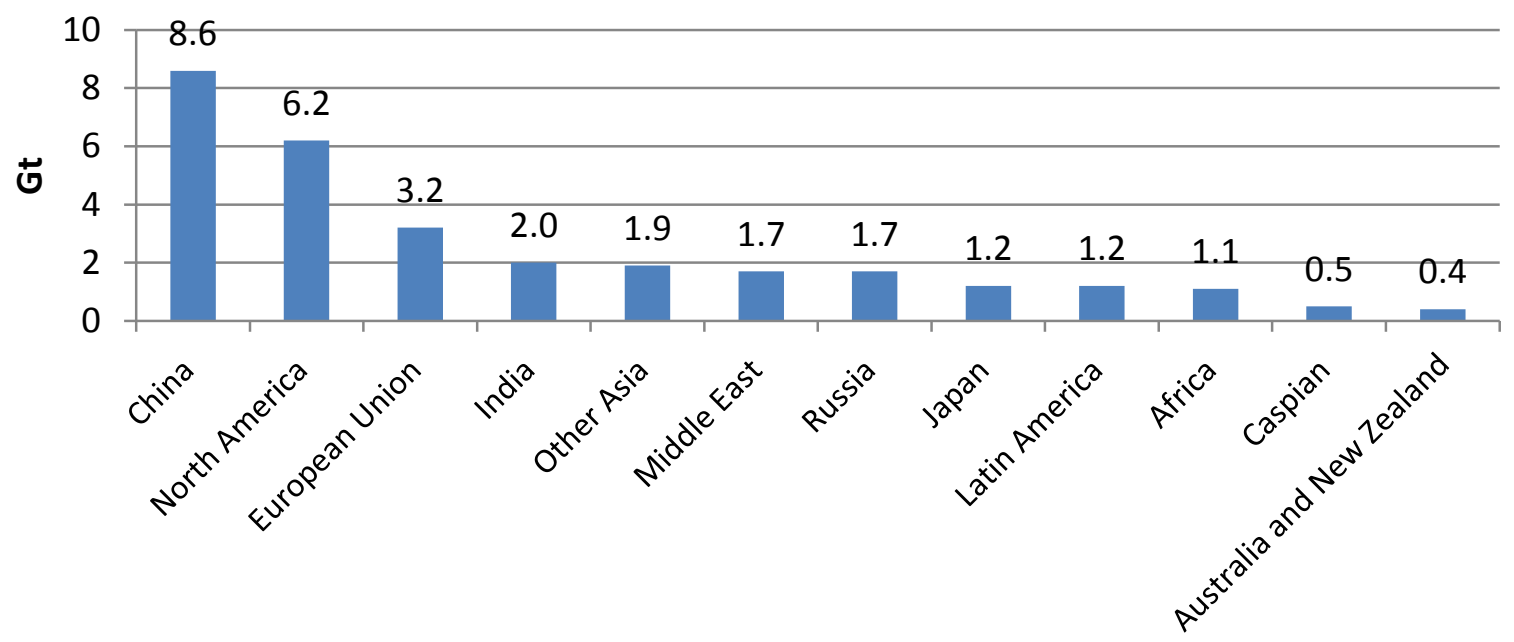

Source: Based on data from IEA (2015d), "Energy and Climate Change", World Energy Outlook Special Report, OECD/IEA, Paris,
https://www.iea.org/publications/freepublications/publication/WEO2015SpecialReportonEnergyandClimateChange.pdf.

Certain national governments in OECD countries have designed their national policy frameworks with resilience in mind. They explicitly recognise the role of cities and sub-national governments in building resilience at the national level, providing them with tools and guidelines to implement programmes at the local scale. Cities' energy policies operate within national and international frameworks, but some pioneering cities have more ambitious visions and targets than those of other levels of government. Fully exploiting cities' potential for managing energy well can enhance resilience and sustainability.

This report explores how cities are able to enhance their resilience in the face of shocks and chronic pressures in the energy sector. In particular, it discusses key policy strategies for managing energy smartly and introduces some good practices for sharing at the city level. It suggests how cities can manage energy effectively by reducing energy demand and by stimulating diversity and flexibility in the energy supply. Different countries and cities have varying conditions relevant to energy demand and supply, including regulation, division of responsibilities between the national and local governments, financial incentives (subsidies and tax), existing energy infrastructure, players in the energy market and currently available energy resources. Therefore, energy policies in cities need to be place-based, and no uniform methodology can be adapted to all cities. The chief objective of this study is to increase awareness of smart energy management among urban policy makers. 


\section{Box 1. The drivers and building blocks of a resilient city}

Cities have four drivers; economy, society, environment and institution (governance), which lead them to be resilient. These four drivers are interconnected to each other; namely, one driver will support other drivers. Each driver has several components. Energy is structured in "environmental" driver of resilience, in particular, one of the adequate resources, whose availability will make cities more resilient in shocks (e.g. in the event of disruption of energy sources and networks) and chronic pressure (e.g. constant shortage of energy...).

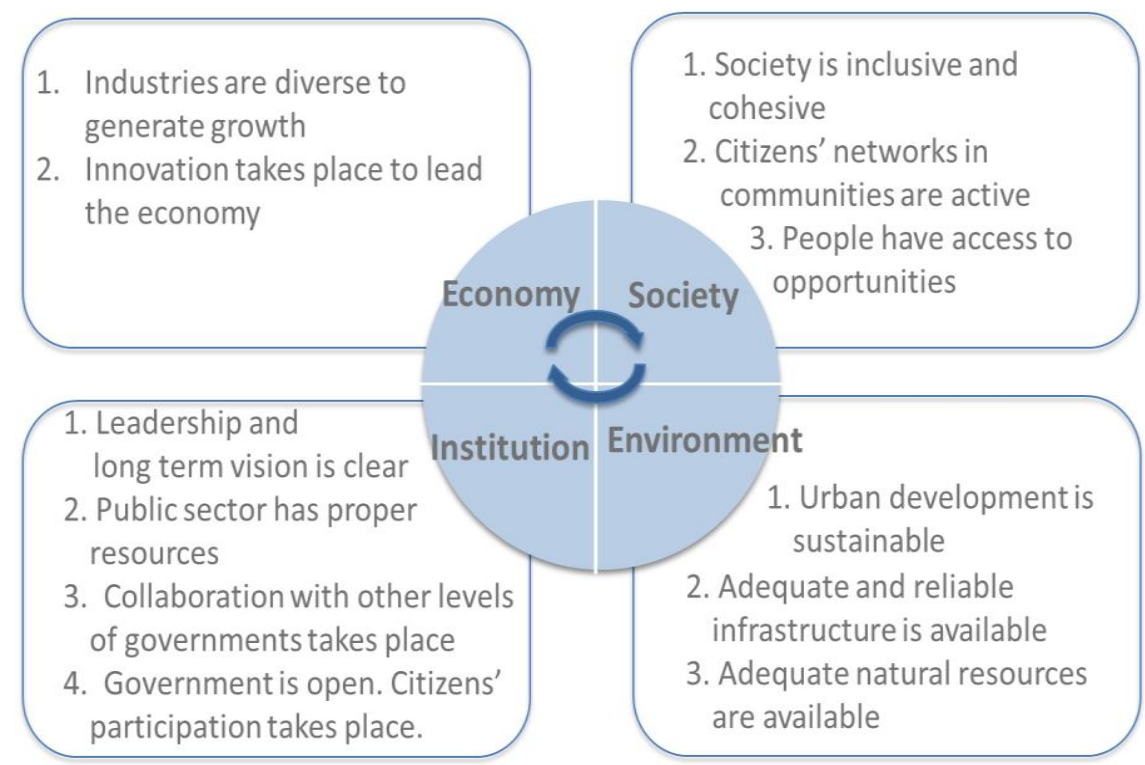

Source: OECD (2015a), "Resilient Cities, Framework for Resilient Cities”, http://www.oecd.org/gov/regional-policy/resilientcities.htm (accessed June 2016).

There are a series of qualities intrinsic to resilient systems, which will have significant economic, social, institutional and environmental repercussions. Listed below are the qualities most recurrent in the literature. They are as applicable to ecosystems and to large industrial infrastructure as they are to cities, and they can manifest through the drivers and characteristics of resilience.

Resilient systems are:

\section{Adaptive: they are able to learn}

- An adaptive urban system manages uncertainty by evolving - modifying standards, norms or past behaviours - using evidence to identify solutions and applying the knowledge gained from past experience when making decisions about the future. There seems to be a general agreement in the literature that adaptive capacity - the ability to learn - is perhaps the most fundamental of all resilience qualities.

\section{Robust: they spread the weight or pressure through the system}

- A robust urban system can absorb shock and emerge unaltered or without significant loss to its functionality or capacity to function. Its degree of robustness rests on the magnitude of shock the system can successfully absorb, and depends on well-designed, built and managed physical assets (e.g. buildings, roads, electrical grids, drainage channels, etc.), ones that can withstand the impact of a shock and continue operating. 


\section{Box 1. The drivers and building blocks of a resilient city (cont.)}

\section{Redundant: they have more than just enough}

- Redundant urban systems are able to meet the need for extra capacity when faced with unexpected demand, a disruptive event, or extreme pressure by intentionally developing or having access to more than one source of action, service or service provider when necessary. Different groups can perform the same function and substitute one another in the case of emergency or change, protecting against a loss of functionality and generating greater response efficiency in times of a crisis. Effective redundancy is planned, cost efficient, and prioritised.

\section{Flexible: they respond to changing circumstances in the moment}

- A flexible urban system allows individuals, households, businesses, communities and government to adjust behaviour or action in order to respond to change in the moment. It helps ensure a minimum level of wellbeing and functional service delivery when under economic, social or environmental stress.

\section{Resourceful: they find ways to meet critical needs with the resources available}

- A resourceful urban system can effectively and quickly restore the functionality of essential services and systems in a crisis situation or under highly constrained conditions, thereby meeting its needs, maintaining its purpose and achieving its aims in times of shock or stress, using the resources available.

\section{Inclusive: they bring diverse perspectives together}

- An inclusive urban system ensures that diverse actors and communities are fully consulted, engaged and empowered in the policy process (e.g. through policy programming and local initiatives), including in the policy design stage when possible.

\section{Integrated: they work together}

- An integrated urban system promotes a co-operative and, ideally, collaborative or "joined-up" approach to policy and programming to better ensure coherent decisions and effective investment. It should experience less duplication and incoherence in operations, management and policy programming, creating more efficient and effective response and outcomes.

Source: OECD (2015a), "Resilient Cities, Framework for Resilient Cities" adapted from ARUP and Rockefeller Foundation (2014), http://www.oecd.org/gov/regional-policy/resilient-cities.htm, City Resilience Framework, Ove Arup \& Partners International Limited, London, UK; Folke, C., S. Carpenter, T. Elmqvist, L. Gunderson, C.S. Holling, B. Walker (2002), "Resilience and Sustainable Development: Building Adaptive Capacity in a World of Transformations," Ambio, Vol. 31, No. 5, August 2002, Royal Swedish Academy of Sciences, Stockholm, Sweden, available at: http://www.eramx.org/biblio/Resilience.pdf ; Chelleri, L. (2012), "From the 'Resilient City' to Urban Resilience: A review essay on understanding and integrating the resilience perspective for urban systems", Documents d'Anàlisi Geogràfica 2012, Vol. 58/2, Universitat Autònoma de Barcelona, Departament de Geografia, Barcelona, Spain; Interagency Resilience Working Group (2012), "The Characteristics of Resilience Building: A discussion paper", PPA Resilience Learning Partnership Group, Bond Disaster Risk Reduction Group, Bond Development and Environment Group, available at: http://technicalconsortium.org/wpcontent/uploads/2014/05/The-Characteristics-of-Res_Building.pdf ; Jha, A.K., Todd W. Miner, and Zuzana Stanton-Geddes, eds. (2013), Building Urban Resilience: Principles, Tools, and Practice. Directions in Development. Washington, DC, World Bank. doi: 10.1596/978-0-8213-8865-5. 
In terms of the methodology and the structure of this report, Chapter 1 examines how energy demand and supply in cities influences resilience in cities from the social, environmental, economic and institutional perspectives. Chapter 2 analyses the policy practices of cities in the OECD countries, and Chapter 3 summarises key policy strategies for managing energy smartly to build resilience in cities. Policy strategies are based on an assessment of policy practices at the city level, as well as the role of national policies and regulations in framing those options. The analysis is conducted with information and statistics collected in a survey of the literature, and through interviews and questionnaires to the relevant organisations. The cities chosen for information collection display an array of social, economic and environmental conditions, and were also selected for their geographical diversity (Table 1).

Table 1. Cities selected for information collection

\begin{tabular}{|c|c|c|c|c|}
\hline & Population & GDP per capita & $\begin{array}{l}\text { GHG emissions } \\
\text { per capita }\end{array}$ & $\begin{array}{l}\text { Energy consumption } \\
\text { per capita }\end{array}$ \\
\hline $\begin{array}{l}\text { Toronto } \\
\text { (Canada) }\end{array}$ & $\begin{array}{l}2808503 \\
(2014)\end{array}$ & $\begin{array}{l}37522 \text { EUR } \\
(2014)\end{array}$ & $\begin{array}{l}7.4 \mathrm{tCO}_{2} \mathrm{e} \\
(2013)\end{array}$ & $\begin{array}{l}\text { 9.2 MWh } \\
\text { (2009) (electricity) }\end{array}$ \\
\hline $\begin{array}{l}\text { Barcelona } \\
\text { (Spain) }\end{array}$ & $\begin{array}{l}1602386 \\
(2014)\end{array}$ & $\begin{array}{l}39632 \text { EUR } \\
(2012)\end{array}$ & $\begin{array}{l}2.3 \mathrm{tCO}_{2} \mathrm{e} \\
(2012)\end{array}$ & $\begin{array}{l}\text { 10.4 MWh } \\
(2012)\end{array}$ \\
\hline $\begin{array}{l}\text { Munich } \\
\text { (Germany) }\end{array}$ & $\begin{array}{l}1517868 \\
(2015)\end{array}$ & $\begin{array}{l}57980 \text { EUR } \\
(2012)\end{array}$ & $\begin{array}{l}7.6 \mathrm{t}^{*} \\
\left(2012, \mathrm{CO}_{2} \text { only) }\right.\end{array}$ & $\begin{array}{l}\text { 23.7 MWh } \\
(2012)\end{array}$ \\
\hline $\begin{array}{l}\text { Kyoto } \\
\text { (Japan) }\end{array}$ & $\begin{array}{l}1468019 \\
(2015)\end{array}$ & $\begin{array}{l}30531 \text { EUR } \\
(2012)\end{array}$ & $\begin{array}{l}5.4 \mathrm{tCO}_{2} \mathrm{e} \\
(2013)\end{array}$ & $\begin{array}{l}\text { 15.2 MWh } \\
(2012)\end{array}$ \\
\hline $\begin{array}{l}\text { Bristol } \\
\text { (UK) }\end{array}$ & $\begin{array}{l}442500 \\
(2014)\end{array}$ & $\begin{array}{l}30298 \text { EUR } \\
(2014)\end{array}$ & $\begin{array}{l}5.5 \mathrm{t}^{*} \\
\text { (2008, } \mathrm{CO}_{2} \text { only) }\end{array}$ & $\begin{array}{l}0.1 \mathrm{MWh} \\
\text { ( } 2014) \text { (electricity, by } \\
\text { city council) }\end{array}$ \\
\hline $\begin{array}{l}\text { Perpignan } \\
\text { (France) }\end{array}$ & $\begin{array}{l}120959 \\
(2013)\end{array}$ & $\mathrm{N} / \mathrm{A}$ & $\begin{array}{l}9.4 \mathrm{tCO}_{2} \mathrm{e} \\
(2012)\end{array}$ & $\begin{array}{l}5.2 \mathrm{MWh} \\
(* *) \text { (electricity) }\end{array}$ \\
\hline $\begin{array}{l}\text { Perpignan Méditerranée } \\
\text { Communauté Urbaine }\end{array}$ & $\begin{array}{l}266611 \\
(2015)\end{array}$ & $\mathrm{N} / \mathrm{A}$ & $\begin{array}{l}9.8 \mathrm{tCO}_{2} \mathrm{e} \\
(2014)\end{array}$ & $\begin{array}{l}19.5 \mathrm{MWh} \\
(2014)\end{array}$ \\
\hline
\end{tabular}

Note: * GHG emissions data for Munich and Bristol are for the metropolitan areas. According to the EU-OECD definition, metropolitan areas are functional urban areas with a population of between 500000 and 1.5 million people; where functional urban areas are the densely populated municipalities and adjacent cities with high levels of commuting towards the densely populated urban cores (OECD, 2012b).

** Estimations based on data available; Electricity: 2014, Population: 2012.

GDP was collected in local currency units and converted into euros, using specific countries PPP (Purchasing Power Parity) conversion factors and PPP for the 28 European countries as a basis. GDP per capita and energy consumption per capita are author's own calculation, based on the relevant population data.

Source: City of Toronto (2015a), "Economic Indicators - August 2015", available at: http://www1.toronto.ca/City\%20Of\%20Toronto/Economic\%20Development\%20\&\%20Culture/Business\%20Pages/News,\%20Re ports\%20\&\%20Resources/August\%202015\%20-\%20current\%20issue.pdf; City of Toronto (n.d.a), "Economic Data Centre", http://www1.toronto.ca/wps/portal/contentonly?vgnextoid=e71032d0b6d1e310VgnVCM10000071d60f89RCRD (accessed March 2016); City of Toronto (2015b), 2013 Greenhouse Gas Inventory, available at http://www.toronto.ca/legdocs/mmis/2016/pe/bgrd/backgroundfile-87697.pdf; City of Toronto (2009), "The Power to Live Green $\begin{array}{llll}\text { Toronto's Sustainable } & \text { Snergy }\end{array}$ http://www1.toronto.ca/city_of_toronto/environment_and_energy/key_priorities/files/pdf/2009-10_report.pdf; Ministry of Finance, Ontario (2010), "Ontario Population Projections Update, 2009-2036", Toronto, Ontario, available at: http://www.fin.gov.on.ca/en/economy/demographics/projections/projections2009-2036.pdf; Barcelona City Council (n.d.b), Statistics website, http://www.bcn.cat/estadistica/angles/dades/index.htm (accessed September 2015); Barcelona City Council (n.d.c), "Statistical Yearbook of Barcelona City website, Energy and Climate Change", http://www.bcn.cat/estadistica/angles/dades/anuari/index.htm (accessed September 2015); City of Munich (n.d.b), "Statistiches Amt', http://www.muenchen.de/rathaus/Stadtinfos/Statistik.html (accessed September 2015); Referat für Gesundheit und 
Umwelt (2014), "CO2-Monitoring 1990 - 2012", http://www.ris-muenchen.de/RII/RII/DOK/SITZUNGSVORLAGE/3319421.pdf (accessed February 2016); City of Kyoto (2015a), "Civic economic calculation", City of Kyoto, Kyoto, http://www2.city.kyoto.lg.jp/sogo/toukei/Economy/Accounts/index.html (accessed 18 December 2015); City of Kyoto (2015b), "GHG emissions in 2013", City of Kyoto, Kyoto, http://www.city.kyoto.lg.jp/kankyo/page/0000186835.html (accessed 18 December 2015); City of Kyoto (2015c), "Kyoto city statistics portal", City of Kyoto, Kyoto, https://www2.city.kyoto.lg.jp/sogo/toukei/index.html (accessed 18 December 2015); Questionnaire to the City of Kyoto; Bristol City Council (2015b), "State of Bristol - Key Facts 2015", Bristol City Council, Bristol, available at: https://www.bristol.gov.uk/documents/20182/32947/State\%20of\%20the\%20City\%202013-

\%20Mayoral\%20vision\%20v8.pdf/cd19638b-9a4d-4b40-833f-c5866896db17; Bristol City Council (2014), "Environmental Statement", available at: http://ec.europa.eu/environment/emas/pdf/videoPage/ES_Bristol_City_Council.pdf; INSEE (n.d.a), "Commune de Perpignan", http://www.insee.fr/fr/themes/comparateur.asp?codgeo=COM-66136 (accessed 16 December 2015); own calculations based on Perpignan Méditerranée (2012) "Plan Climat-Énergie Territorial de PMCA et de Perpignan 20122017' (Territorial Climate-Energy Plan of PMCA and Perpignan 2012-2017), (September), available at: http://agenda21perpignanmediterranee.com/wp-content/uploads/plan-climat-perpignan-pmca.pdf; INSEE (n.d.b), "Populations légales 2013 Perpignan" (Legal population data of 2013 - Perpignan), http://www.insee.fr/fr/ppp/bases-de-donnees/recensement/populationslegales/commune.asp?annee=2013\&depcom=66136 (accessed March 2016); Perpignan City Council (n.d.), "Principaux éléments à retenir des diagnostics de 2012" (Main elements to remember about 2012 diagnoses), http://www.mairieperpignan.fr/fr/cadre-vie/plan-climat-grenelle/bilan-emissions-gaz-effet-serre/principaux-elements-retenir, (accessed March 2016); Perpignan's answers to the OED questionnaire; Perpignan Méditerranée (n.d.a), "La Communauté urbaine c'est quoi?" (What is the Communauté Urbaine?), http://www.perpignanmediterranee.com/L-agglo-c-est-quoi--5145.phtm, (accessed March 2016); Perpignan Méditerranée (2016), "Bilan Carbone, Le Diagnostic Local" (Carbon assessing, the local diagnosis), Délégation Générale au Développement Durable - Communauté Urbaine Perpignan Méditerranée, France, available at: http://www.perpignanmediterranee.com/fichiers agglo/documents/DDbilancarbone2014complet.pdf; OECD (2012c), "The OECD Metropolitan Areas Database", OECD, Paris, http://measuringurban.oecd.org/\#story=0 (accessed 3 December 2015). 


\section{HOW ENERGY CAN INFLUENCE RESILIENCE IN CITIES}

\subsection{Urbanisation and energy}

\subsubsection{Energy demand in cities}

Energy demand in cities is projected to grow by $57 \%$ between 2006 and 2030, about 2.7 times more than the growth forecast for areas outside cities (Figure 2). It is expected to account for $73 \%$ of the world's energy consumption by 2030 . Total final consumption of energy per capita correlates with the share of urban population in the OECD countries (Figure 3). Energy consumption in cities is primarily based on fossil fuels in general. The share of fossil fuels in urban energy demand was $86 \%$ in 2006, substantially higher than the 69\% outside cities (Figure 4). The current wave of urbanisation is both a risk and an opportunity (OECD, 2015b). Various differences exist between cities and areas outside cities with respect to the conditions that can affect energy demand. These include, for example, diversity of functions, whether industrial, commercial or administrative, size and types of housing and buildings, density, land use and dominant transport mode.

Figure 2. Estimated energy demand in cities

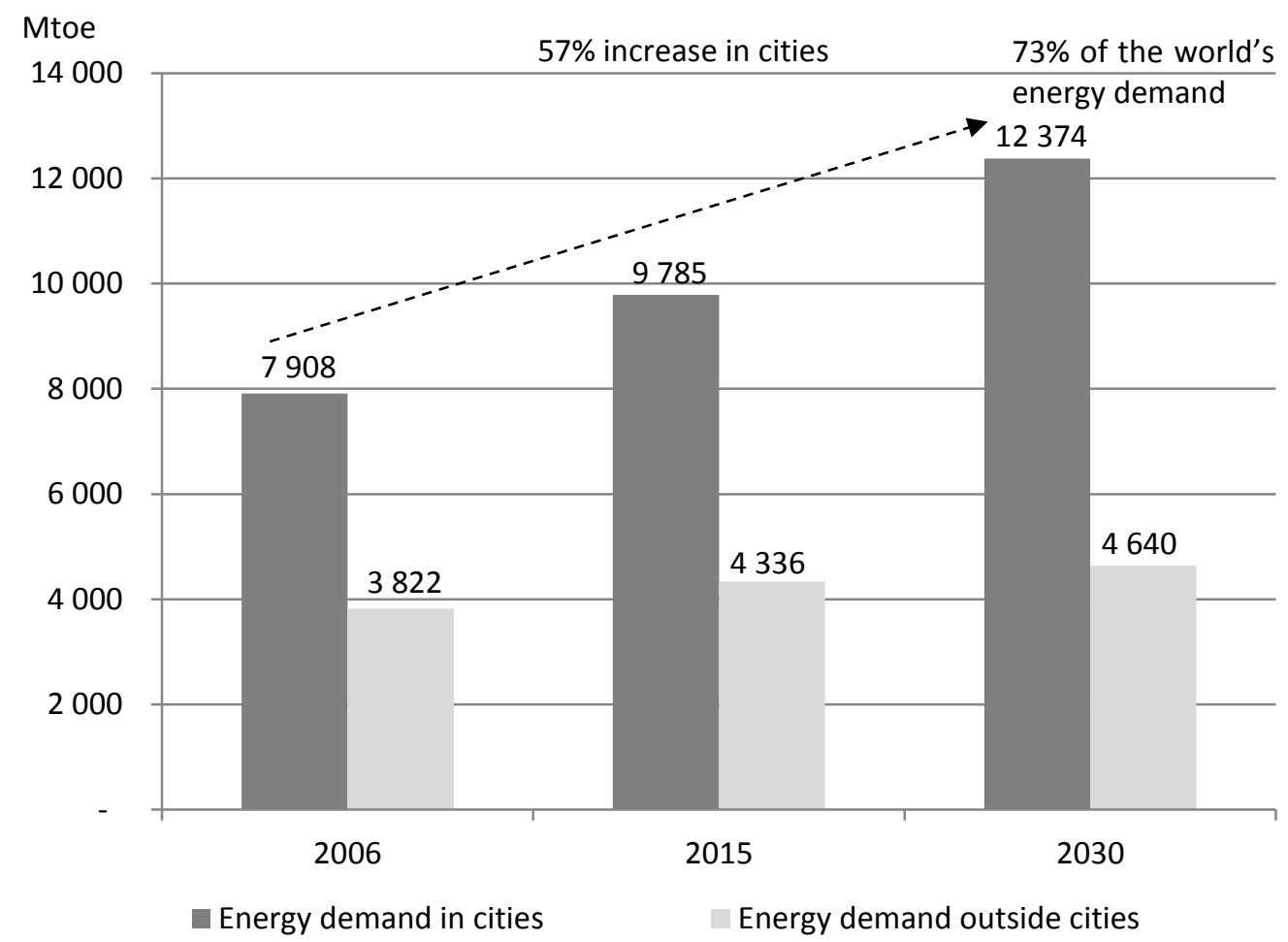

Note: "Cities" refers to all urban areas, from megacities to smaller-scale urban settlements. Energy demand was calculated by data including the US, EU, Australia, New Zealand, China, Tokyo and Moscow (IEA, 2008). "Outside cities" refers to the area outside the aforementioned "cities".

Source: IEA (2008), "World Energy Outlook 2008”, OECD Publishing, Paris, http://dx.doi.org/10.1787/weo-2008-en. 
Figure 3. Urban population share and total final consumption of energy per capita

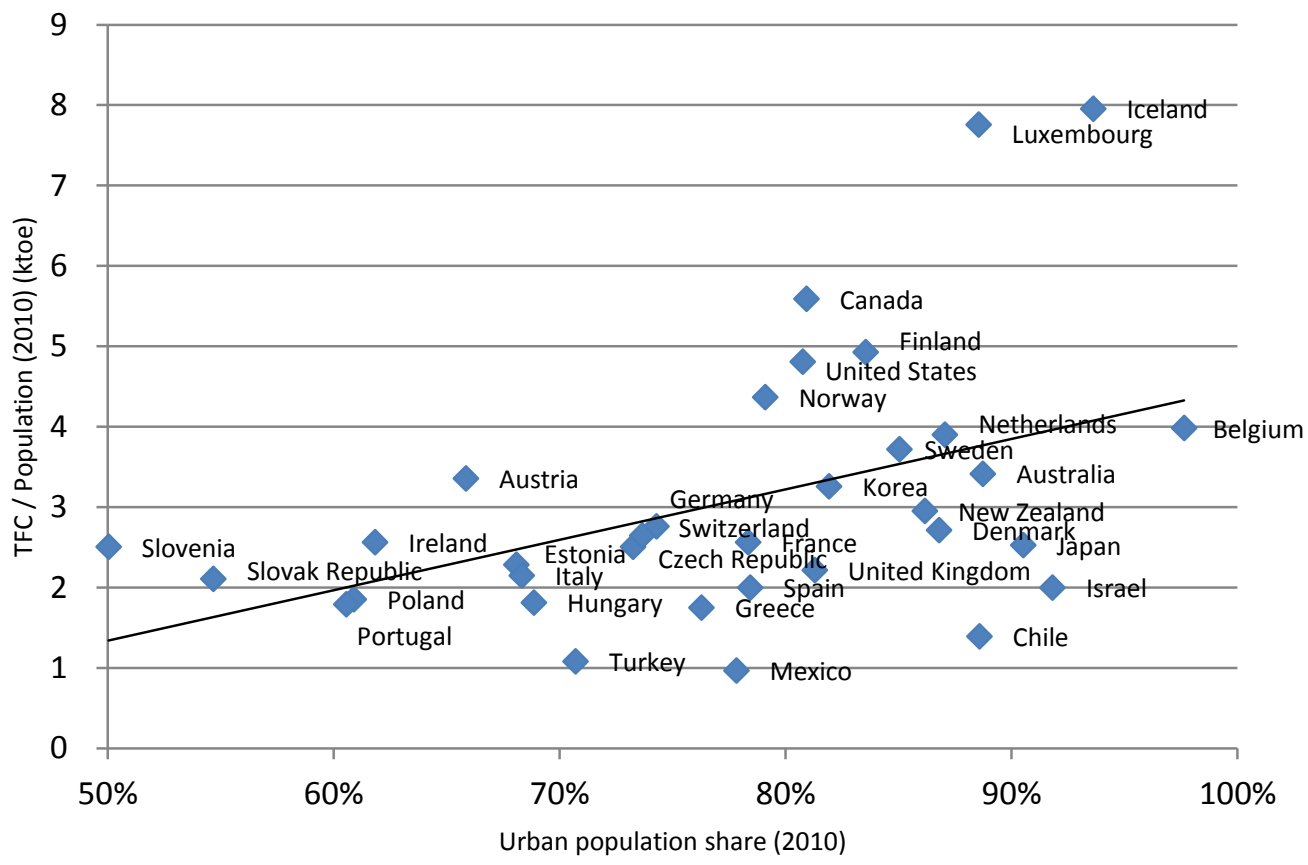

Note: Urban population share is from the United Nations (2014), whose estimates are taken from the most recently available census or official population estimate of each country, and follows the definition of "urban" population used in each country.

Source: Based on data from OECD (2015c), "Energy Balances of OECD Countries 2015", OECD Publishing, Paris, available at: http://dx.doi.org/10.1787/energy bal oecd-2015-en; United Nations (2014), "World Urbanization Prospects: The 2014 Revision", http://esa.un.org/unpd/wup/CD-ROM/ (accessed 3 December 2015).

Figure 4. Energy demand by fuel type (2006)

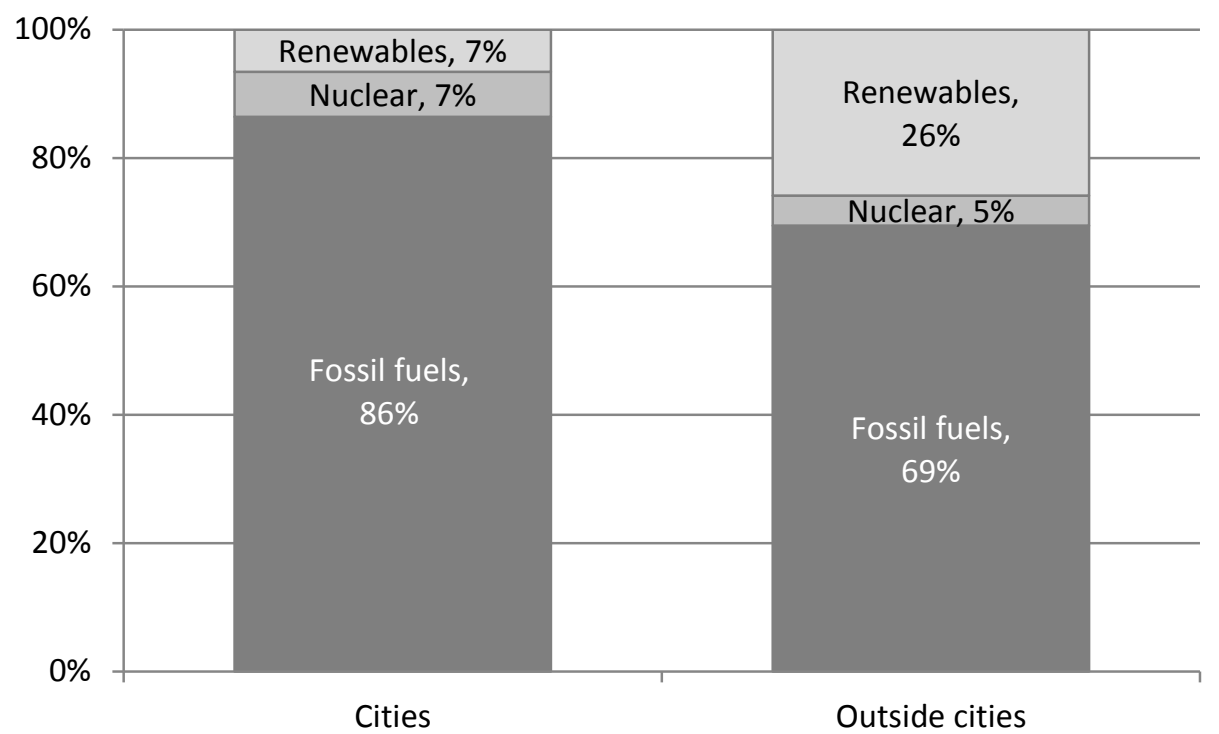

Note: Renewables include hydro, biomass and waste, and other renewables. Fossil fuels include coal, oil and gas.

Source: Based on data from IEA (2008), "World Energy Outlook 2008”, OECD Publishing, Paris, http://dx.doi.org/10.1787/weo2008-en. 
Efforts have been made to improve the energy efficiency of commercial and residential buildings and of appliances. Rising global awareness has helped build international consensus on the importance of energy production and consumption for climate change mitigation. Energy efficiency does not just mean reducing energy consumption, but includes the aspects of benefits gained from energy use, as described in EU 2012 Energy Efficiency Directive, the ratio of output of performance, service, goods or energy to input of energy. Information and communication technologies (ICT) can help cities manage energy more easily. Thanks to these technologies, for instance, smart meters that keep track of energy consumption in residential buildings now provide financial incentives to citizens and greater awareness of more efficient energy use. However, because energy demand in cities is expected to increase, there is much more cities can and should do to increase energy efficiency.

\subsubsection{Energy supply in cities}

Total primary energy supply in the OECD area was 5238 Mtoe (million tons of oil equivalent) in 2014, 16\% higher than in 1990 (OECD, 2015c). Total energy production in the OECD area has fluctuated between 3800 Mtoe and 3900 Mtoe per year since the late 1990s. Energy production by fossil fuels has increased 779 Mtoe between 1971 and 2013, and the growth is larger than that of renewables (293 Mtoe) and nuclear (484 Mtoe) in the OECD area (OECD, 2015e). The growth rate of energy production correlates with the GDP growth rate to some extent (Figure 5). Renewable energy production has been growing rapidly since the early 2000s. Between 2004 and 2013, renewable energy production grew by $39 \%$, accounting for approximately $12 \%$ of total energy production in the OECD area in 2013 (Figure 6). These positive trends are linked to policy interventions through subsidies, grants and regulations from national and supra-national authorities intended to support renewable energy deployment. The main drivers are energy security concerns, climate change mitigation and the wider environmental impact of fossil fuel use (OECD, 2012a).

Rural areas tend to attract renewable energy deployment, as most renewable technologies are space-intensive and rely to some extent on rural resources (e.g. biomass) (OECD, 2012a). In urban areas, data from the selected cities suggest that only a small amount of energy demand is met by local renewable energy production, as for instance $0.9 \%$ in Kyoto (Table 2). The deployment of renewable energy in terms of capacity of facilities per energy consumption is smaller in urban than in rural regions (Figure 7). However, according to certain studies, cities have untapped renewable energy resources. For instance, an estimate by the US Department of Energy shows that urban utility-scale PV (photovoltaics) has the technical potential to generate $2200 \mathrm{TWh}$ (Table 3), and even higher potential exists for other technologies, including rooftop PV in US urban areas. This suggests that urban areas have considerable renewable energy potential, considering that aggregate electric retail sales in all 50 US states were approximately 3754 TWh in 2010 (Table 3). 
Figure 5. GDP growth and energy production growth in OECD



Source: Own calculations based on OECD (2015e), "OECD.Stat", OECD, Paris, http://stats.oecd.org/ (accessed 25 February 2016).

Figure 6. Energy production by energy sources in OECD



Source: Based on data from OECD (2015e), “OECD.Stat”, OECD, Paris, http://stats.oecd.org/ (accessed 3 December 2015). 
Table 2. Share of local renewable energy production in total energy consumption of selected cities

\begin{tabular}{|c|c|c|}
\hline & $\begin{array}{c}\text { Share of local renewable energy } \\
\text { production in energy consumption }\end{array}$ & Population (thousands) \\
\hline Barcelona (Spain) & $1.7 \%$ & 1616 \\
\hline Kyoto (Japan) & $0.9 \%$ & 1474 \\
\hline Nottingham (UK) & $11.5 \%$ & 306 \\
\hline Perpignan (France) & $4.2 \%$ & 120 \\
\hline $\begin{array}{c}\text { Perpignan Méditerranée } \\
\text { Communauté Urbaine }\end{array}$ & $12.7 \%$ & 266 \\
\hline Sakai (Japan) & $2.2 \%$ & 842 \\
\hline
\end{tabular}

Source: Barcelona City Council and Barcelona Energy Agency (2013), "Barcelona Energy Self-Sufficiency Plan" (brochure), (April) (Dates of 2008), available at: http://www.energy-cities.eu/IMG/pdf/Barcelona-Energy-Agency Irma-Soldevilla.pdf; Barcelona City Council (n.d.b), Statistics website, http://www.bcn.cat/estadistica/angles/dades/index.htm (accessed September 2015); City of Kyoto (2013b), "Information on Kyoto city strategy for promoting energy policy", City of Kyoto, Japan, http://www.city.kyoto.lg.jp/kankyo/page/0000161721.html (accessed 27 March 2015); Statistics Bureau of Japan (2011), "Population census 2010", Statistics Bureau of Japan, Tokyo, http://www.stat.go.jp/data/kokusei/2010/ (accessed 27 March 2015); Nottingham City Council (2010), "Energy Strategy 2010-2020", Nottingham City Council, Nottingham, available at: http://www.nottinghamcity.gov.uk/CHttpHandler.ashx?id=19119\&p=0; Office for National Statistics, UK (2012), "2011 Census, Population and Household Estimates for England and Wales", Office for National Statistics, Newport, http://www.ons.gov.uk/ons/publications/re-reference-tables.html?edition=tcm\%3A77-257414 (accessed 27 March 2015); INSEE (n.d.a), Commune de Perpignan, http://www.insee.fr/fr/themes/comparateur.asp?codgeo=COM-66136 (accessed 16 December 2015); interview with the City of Perpignan and Perpignan Méditerranée Communauté Urbaine by the OECD Secretariat; Perpignan Méditerranée (2016), "Bilan Carbone, Le Diagnostic Local" (Carbon assessment, the local diagnosis), Délégation Générale au Développement Durable - Communauté Urbaine Perpignan Méditerranée, France, available at: http://www.perpignanmediterranee.com/fichiers agglo/documents/DDbilancarbone2014complet.pdf; Sakai city (2011), "Energy supply and demand of Sakai City in 2011", Sakai, Japan, available at: http://www.city.sakai.lg.jp/shisei/gyosei/shishin/kankyo/ondanka/energy policy.files/follow-up2011.pdf.

Figure 7. Deployment of renewable energy facilities per unit of energy consumption (Japan)



Note: PU: predominantly urban (region), IN: intermediate (region), PRC: predominantly rural (region) close to a city, PRR: predominantly rural remote (region). Renewable energy facilities: photovoltaic power, wind power, small and medium hydropower, biomass power and geothermal power. Deployment of renewable energy facilities: deployment capacity of renewable energy facilities certified under FIT scheme.

Source: Agency for Natural Resources and Energy (2014a), "Energy consumption statistics by prefecture", Agency for Natural Resources and Energy, Tokyo, http://www.enecho.meti.go.jp/statistics/energy consumption/ec002/results. html\#headline2 (accessed 27 March 2015); Agency for Natural Resources and Energy (2014b), "Website for information of Feed-in tariff", Agency for Natural Resources and Energy, Tokyo, http://www.fit.go.jp/statistics/public sp.html (accessed 27 March 2015). 
Table 3. Estimated technical potential of solar energy generation (US)

\begin{tabular}{|l|l|l|}
\hline \multicolumn{2}{|l|}{ Energy consumption in 50 states (TWh) } & 3754 \\
\hline \multirow{2}{*}{ Generation potential (TWh) } & Urban utility-scale PV & 2200 \\
\cline { 2 - 3 } & Rooftop PV and others & 199000 \\
\hline
\end{tabular}

Table 4. Note: Others include concentrating solar power, onshore wind power, offshore wind power, biopower, hydrothermal power systems, enhanced geothermal systems and hydropower. Potential of urban utility-scale PV was estimated by excluding areas not suitable for technology, including steep slopes, parking lots, roads and areas unsuitable for development and too small for utility-scale projects. Potential of rooftop PV was estimated by calculating usable roof areas, considering the conditions of roofs including shading, rooftop obstructions and constraints.

Source: Based on Data from Lopez A. et al (2012), "U.S. Renewable Energy Technical Potentials: A GIS-Based Analysis", National Renewable Energy Laboratory, Colorado, available at: http://www.nrel.gov/docs/fy12osti/51946.pdf.

\subsubsection{Energy data at city level}

Energy data at city level, including data on energy consumption and renewable energy production, are fundamental for understanding resilience challenges related to energy and for developing urban policies. The OECD countries collect energy data, including consumption, production, imports and exports at the national level. National governments also estimate energy data at narrower territorial levels. However, availability issues emerge in collecting data at the city level, especially at municipality level. According to the IEA (2008), energy data at city level are difficult to find, often incomplete and rarely presented in a format that allows for comparisons between cities or with national data (IEA, 2008), because reporting methods are not standardised. Currently, energy data at the city level are difficult to measure directly. Indirect methods are usually used for estimation of energy consumption, because cities take in energy, including electricity, gas and oil, from outside their areas, through energy plants and grids for energy distribution that are beyond administrative boundaries.

Some cities estimate energy data at the municipal level, including energy consumption and production (Table 4) and utilise this for target setting. Examples of the methodologies of Japan's local governments are introduced in its government guidelines for developing energy consumption statistics at the municipal level (MOE, 2007). These estimate energy consumption data at the municipal level based on statistics including sales results from energy companies, household income and expenditure surveys, proportional division of data at the prefecture level, and comprehensive energy statistics. It is suggested that Japanese cities use these methodologies to calculate energy consumption data, the basis for developing local plans for reducing GHG emissions stipulated in Japan's Law Concerning the Promotion of Measures to Cope with Global Warming. Other methodologies are used in the cities of OECD countries, for example using analytical software to estimate energy data, and by collaborating with local stakeholders to obtain energy data at the city level.

Kyoto estimates energy consumption and renewable energy production data at city level. The city utilises this information to set the targets related to the reduction of energy consumption and the deployment of renewable energy. Energy consumption in the city is approximately $23334 \mathrm{GWh}$ in 2011, and has fallen $14 \%$ in the period from 1990 to 2011 . Energy consumption has decreased by $52 \%$ in the industrial sector and by $23 \%$ in the transport sector over the same period. The city attributes this reduction in energy consumption in the industrial sector to economic trends and changes in the industrial structure, given that energy consumption has fallen in parallel with the decrease in shipments of manufactured goods. On the other hand, energy consumption over the same period increased by $19 \%$ in the business sector and by $27 \%$ in the residential sector, which together account 
for approximately $60 \%$ of the total energy consumption in the city. The city has also analysed why energy consumption in these sectors has risen. In the business sector, the square footage of commercial property in use has increased, although energy consumption per square foot has fallen, and in the residential sector, energy consumption per capita has increased, although energy consumption per household has dropped. The city also collects and publishes data on the deployment of renewable energy in the city, which amounted to a total of $154.25 \mathrm{GWh}$ in 2011 . The city has also conducted a survey on the availability and potential quantity of renewable energy, showing that solar energy accounted for $97.2 \%$, at 1.028 million $\mathrm{GWh} /$ year, and that the availability is $0.4 \%$ in potential quantity (City of Kyoto, 2013b).

Munich uses the ECORegion software (Box 2), adopted by approximately 300 cities in Germany, to analyse energy data (City of Munich, 2013). Total energy consumption amounted to approximately 23.7 MWh per capita in 2012, after it fell by 23.5\% between 1990 and 2012 (City of Munich, 2014a). Electricity accounted for 22\% of energy consumption in the city in 2012 (City of Munich, 2014a) and renewable electricity accounted for $25.4 \%$ of total electricity consumption in 2013 (City of Munich, n.d.a). Munich's Department of Construction assesses energy consumption of the city's administration and public infrastructure. Overall final energy consumption within the city's administration has been reduced from approximately $0.9 \mathrm{MWh}$ per capita in 1990 to approximately $0.64 \mathrm{MWh}$ per capita in 2012, due to the reduction in fuel and heat consumption that resulted from active policies of housing retrofit and district heating infrastructure (City of Munich, 2014a). Electricity consumption, however, increased by $25 \%$ in city-owned buildings and by $3.6 \%$ in public transport over the same period.

\section{Box 2. Monitoring energy and $\mathrm{CO}_{2}$ emissions - The ECORegion software}

ECORegion software is available online, and was launched in 2008 for municipalities to monitor the evolution of several energy indicators (e.g. energy consumption) and $\mathrm{CO}_{2}$ emissions. It provides cities with a standardised methodology to measure and estimate energy and pollution trends. The resulting data can then be compared across the cities and countries where the software is available: in Germany (where it is used by 300 cities), France, Switzerland and Italy. It was developed by the association Climate Alliance, the Swiss company EcoSpeed and the firm B\&SU GmbH. According to pre-registered information on the country and the territory to which the city belongs (e.g. population, and kilometres travelled by the city's inhabitants), the software provides estimates of $\mathrm{CO}_{2}$ emissions. For each city, the software provides either overall data or data broken down by sector: households, private sector, public facilities and the transport sector. The ultimate goal of the software is to allow local governments to assess the impact of the energy policies they implement and to adjust them if needed. This can help them build the resilience to withstand any shocks they may face over time.

Source: Climate Alliance (2015), "Energy and $\mathrm{CO}_{2}$ monitoring", http://www.climatealliance.org/co2-monitoring0.0.html (accessed January 2016).

Toronto is committed to regularly monitor and evaluate energy and environmental data through the "Climate Change, Clean Air and Sustainable Energy Action Plan" (City of Toronto, 2007). The city monitors energy consumption, renewable energy production, and GHG and smog-causing emissions, in order to assess the impact of energy policies on the local economy, to evaluate progress towards energy sustainability, and to identify primary sources of emissions and energy consumption in order to design targeted and more efficient policies (City of Toronto, 2015b). Data are either collected by the city council or provided by Toronto's energy utility companies, since they are required to share some information with the council (City of Toronto, 2007). The largest consumer of electricity in the 
city is the commercial sector, with $58 \%$ of the total, followed by the residential sector, with $30 \%$, and the industrial sector, with $10 \%$. The residential sector is the largest consumer of natural gas, at $54 \%$ in 2009, followed by the commercial sector (30\%) and the industrial sector (14\%) (City of Toronto, 2009). The council also provides annual reports on environmental achievements and the challenges ahead, in terms of energy sustainability and economic and health assessments. Toronto's sustainable energy policy is revised each year depending on the progress of the policies (City of Toronto, 2007, City of Toronto, 2014b).

The city of Perpignan and the cities in its vicinity have agreed to cover the residential electricity needs of the whole agglomeration, using renewable energy locally produced in the 36 cities of the conurbation. Energy data from the urban agglomeration is used to track the goals that they have set. Total renewable energy produced in the Perpignan Méditerranée Communauté Urbaine amounted to $670 \mathrm{GWh}$ in 2016 (Perpignan Méditerranée, 2015), and the renewable energy produced in the city of Perpignan totalled $26 \mathrm{GWh}$ in 2014. Two-thirds of the renewable energy produced in the area in 2013 came from solar PV. In 2016, $42 \%$ of renewable energy produced in the area of the Communauté Urbaine was derived from wind sources.

Bristol provides energy data on the energy consumption patterns of the city council. Its electricity consumption was reduced from around 80GWh in 2011 to 60GWh in 2014 (Bristol City Council, 2014). The private sector in the city also collects energy data, since the national "Mandatory Carbon Reporting" regulation introduced in 2013 requires listed and major companies to report their carbon emissions, monitor their energy usage regularly and assess their energy efficiency measures.

Barcelona collects energy data and emissions totals, and maps the installation of renewable energy plants (Barcelona City Council and Barcelona Energy Agency, 2013). Total final energy consumption had been increasing until 2005, and fell after 2010, mainly as a result of the economic crisis. In 2012, the residential sector has become its largest consumer of energy, accounting for $29.3 \%$ of the city's total energy consumption. The city council, through its activities and mainly through its building stock, consumed approximately $472250 \mathrm{MWh}$ in 2008 , of which $1.4 \%$ came from solar thermal sources. In 2008, renewable energies represented $0.6 \%$ of all energy consumed in the city as a whole (Barcelona City Council, (n.d.a)). Local production of renewable energy has risen from 6680 MWh in 1999 to $153620 \mathrm{MWh}$ in 2012. Biogas and hydropower account for a smaller proportion of the total: in 2008, 1.47 GWh was produced by small-hydro plants and $35.04 \mathrm{GWh}$ of biogas was generated by eco-parks' municipal waste treatment facilities (Barcelona City Council, n.d.a).

Table 4. Energy consumption and local renewable energy production in selected cities

\begin{tabular}{|l|l|l|}
\hline City & Energy consumption & Local renewable energy production \\
\hline Barcelona & $\begin{array}{l}\text { 60 415 TJ (2012) } \\
\text { By sector (industry: 18.84\%, transport: } \\
22.84 \%, \text { residential: } 29.27 \%, \text { commercial: } \\
29.04 \%)(2012)\end{array}$ & $\begin{array}{l}\text { 553 TJ (2012) } \\
\text { By source (solar PV: 10\%, solar thermal: } 46 \%, \\
\text { small-scale hydro: } 2 \%, \text { biogas: 34\%, biomass: } \\
8 \%)(2012)\end{array}$ \\
\hline Bristol & 216 TJ (2014) (electricity, by the city council) & \\
\hline
\end{tabular}


Table 4. Energy consumption and local renewable energy production in selected cities (cont.)

\begin{tabular}{|c|c|c|}
\hline Kyoto & $\begin{array}{l}84000 \text { TJ (2011) } \\
\text { By sector (industry: } 16 \% \text {, transport: } 27 \% \text {, } \\
\text { residential: } 27 \% \text {, business: } 31 \%(2011) \\
\text { By source (electricity: } 38 \% \text {; city gas: } 29 \% \text {; } \\
\text { oil: } 33 \%)(2011)\end{array}$ & $\begin{array}{l}\text { 553 TJ (2011) } \\
\text { Potential quantity of RE (solar: } \\
\text { 3.7 million TJ/year, wind: } 935 T \mathrm{~T} / \text { year, small- } \\
\text { scale hydro: } 1 \text { 516TJ/year, biomass: } \\
\text { 8 353TJ/year) (2011) } \\
\text { Quantity of RE available (solar power: } \\
5 \text { 400TJ/year, solar thermal: } 15 \text { 000TJ/year, } \\
\text { wind: } 477 \mathrm{TJ} / \text { year, small-scale hydro: } \\
\text { 108TJ/year, waste power: } 747 \mathrm{TJ} / \text { year, waste } \\
\text { heat: } 2 \text { 695TJ/year) (2011) }\end{array}$ \\
\hline Munich & 123058 TJ (2008) & $\begin{array}{l}8640 \text { TJ (2014) (total Stadtwerke München } \\
\text { GmbH) } \\
469 \text { TJ (2014) (within the city) } \\
\text { By source within the city (solar: } 29.8 \% \text {, wind: } \\
1.2 \% \text {, hydro: } 58.5 \% \text {, biomass: } 10.5 \%)(2014) \\
\text { (electricity) } \\
\text { Installed capacity by source within the city (solar } \\
\text { PV: } 49.975 \mathrm{~kW} / \mathrm{kWp} \text { Hydro: } 15.030 \mathrm{~kW} / \mathrm{kWp} \text {, } \\
\text { biomass: } 5.057 \mathrm{~kW} / \mathrm{kWp} \text { (2014) (electricity) }\end{array}$ \\
\hline Perpignan & 2239 TJ (2014) (electricity) & 94 TJ (2014) (total RE production) \\
\hline $\begin{array}{l}\text { Perpignan } \\
\text { Méditerranée } \\
\text { Communauté } \\
\text { Urbaine }\end{array}$ & $\begin{array}{l}18720 \text { TJ (2014) } \\
\text { By sector (industry: } 4 \% \text {, transport: } 43 \% \text {, } \\
\text { residential: } 33 \% \text {, business: } 19 \%)(2014) \\
\text { By source (electricity: } 29 \% \text {; city gas: } 17 \% \text {; } \\
\text { oil: } 50 \%)(2014)\end{array}$ & $\begin{array}{l}2412 \text { TJ (2016) } \\
\text { By source (solar: } 15 \% \text {, wind: } 42 \% \text {, waste } \\
\text { combustion: } 17 \%)(2016)\end{array}$ \\
\hline Toronto & $\begin{array}{l}\text { Electricity: } 92229 \mathrm{TJ}(2013) \\
\text { (commercial: } 53301.6 \mathrm{TJ} / \text { year, or } 58 \% \text {, } \\
\text { industrial: } 9,190.8 \mathrm{TJ} / \text { year, or } 10 \% \text {, } \\
\text { residential: } 27568.8 \mathrm{TJ} / \text { year, or } 30 \% \text {, other: } \\
1839.6 \mathrm{TJ} / \text { year or } 2 \%)(2009) \\
\text { Natural gas: } 4090 \mathrm{Mm}^{3}(2013) \\
\text { (commercial: } 1303 \mathrm{Mm}^{3} / \text { year, or } 31 \% \text {, } \\
\text { industrial: } 589 \mathrm{Mm}^{3} / \text { year, or } 14 \% \text {, residential: } \\
2270 \mathrm{Mm}^{3} / \text { year, or } 54 \% \text {, other: } 42 \\
\left.\mathrm{Mm}^{3} / \text { year, or } 1 \%\right)(2009)\end{array}$ & $\begin{array}{l}40 \mathrm{MW} \text { of renewable energy capacity (2012) } \\
\text { (solar PV) }\end{array}$ \\
\hline
\end{tabular}

Note: Data were converted by the author (except for Kyoto), by using $1 \mathrm{GWh}=3.6 \mathrm{TJ}$ (conversion factor provided by OECD, 2015c).

Source: Barcelona City Council (n.d.c), "Statistical Yearbook of Barcelona City website, Energy and Climate Change", http://www.bcn.cat/estadistica/angles/dades/anuari/index.htm (accessed September 2015); Bristol City Council (2014), "Environmental Statement", available at: http://ec.europa.eu/environment/emas/pdf/videoPage/ES Bristol City Council.pdf; City of Kyoto (2013b), "Information on Kyoto city strategy for promoting energy policy", City of Kyoto, Japan, http://www.city.kyoto.lg.jp/kankyo/page/0000161721.html (accessed 27 March 2015); City of Munich (2010), "International, Sustainable, United in Solidarity", available at: http://www.wirtschaft-muenchen.de/publikationen/pdfs/ins-en.pdf; City of Munich (2015a), "Entwicklung der EEG-Anlagen in München 2001-2014", Department of Health and Environment, City of Munich, https://www.muenchen.de/rathaus/dms/Home/Stadtverwaltung/Referat-fuer-Gesundheit-und-

Umwelt/Dokumente/Klimaschutz und Energie/Regenerative Energie/web eeg anlagen muc 2014.pdf; (June); Perpignan Méditerranée (2015), "L'Agglo sur le terrain de l'Ecoparc Catalan", http://www.perpignanmediterranee.com/L\%E2\%80\%99Agglo-sur-le-terrain-de-l\%E2\%80\%99Ecoparc-Catalan--6135.phtm; Perpignan Méditerranée (2016), "Bilan Carbone, Le Diagnostic Local' (Carbon assessing, the local diagnosis), Délégation Générale au Développement Durable - Communauté Urbaine Perpignan Méditerranée, France, available at: http://www.perpignanmediterranee.com/fichiers agglo/documents/DDbilancarbone2014complet.pdf. Perpignan's local authorities' answers to the OECD questionnaire; City of Toronto (2009), "The Power to Live Green - Toronto's Sustainable Energy Strategy" (October), available at: http://www1.toronto.ca/city of toronto/environment and energy/key priorities/files/pdf/2009-10 report.pdf. ; City of Toronto (2015b), "Toronto's 2013 Greenhouse Gas Inventory”, available at: http://www.toronto.ca/legdocs/mmis/2016/pe/bgrd/backgroundfile-87697.pdf; City of Toronto (2015c), "Toronto Environmental Progress Report 2015”, Toronto, available at: http://www.toronto.ca/legdocs/mmis/2016/pe/bgrd/backgroundfile-90610.pdf. 
Data is also useful for assessing the impact of policies. It can help policy makers better assess the current situation and identify the problems to be addressed. Tracking the progress in achievement of the targets contributes to updating and modifying urban energy policies. Cities measure policy impacts by monitoring energy data and indicators relevant to their targets. Indicators relevant to energy and its relations to sustainability have also been developed. For example, ISO 37120:2014 "Sustainable development of communities: Indicators for city services and quality of life" defines and establishes methodologies for a set of indicators to steer and measure the performance of city services and quality of life. The standard has some indicators relevant to energy, including total electricity energy use per capita, percentage of total energy derived from renewable sources as a share of the city's total energy consumption, average number of electrical interruptions per customer per capita, and average length of electrical interruptions.

Policy impacts are primarily measured by the changes in energy data, including energy consumption reductions and renewable energy deployment. For instance, Perpignan estimates that it saved 3 million KW of gas and 363 hectolitres of fuel on its own consumption between 2013 and 2014, with the Energy Performance Contract on buildings management, defined under the EU Energy Enduse Efficiency and Energy Services. The city's street lighting modernisation programme has saved $11 \mathrm{GWh}$ in electricity since 2009 (Perpignan City Council, 2015). Perpignan Méditerranée reports its renewable energy production at $670 \mathrm{GWh}$ in 2016 , which corresponds to $65 \%$ of its residential electricity consumption, 33\% of its electricity needs and $22 \%$ of its total energy consumption, transport excluded. In 2014, the Communauté Urbaine produced 232 GWh (Perpignan Méditerranée, 2015), which corresponds to $42 \%$ of its target values for becoming a positive energy area, which would require $550 \mathrm{GWh}$ in renewable energy production per year.

Policy impacts are also measured by the data relevant to the economic, environmental and social performance of the cities. For instance, energy programmes in Bristol are considered to have enhanced the environmental resilience of the city by reducing $\mathrm{CO}_{2}$ emissions by $15 \%$ between 2005 and 2009 (Bristol City Council, n.d.a), and the wind farm has helped cut 5000 tonnes of $\mathrm{CO}_{2}$ per year (Bristol City Council, n.d.b). Economic spillovers are also found in Bristol, where the expansion of renewable energies and the construction of a wind farm have enabled local authorities to save GBP 1.3 million and to reinvest it in energy projects in the city (Bristol 2015, 2015a). Beyond the savings in the cost of energy, the "WarmUp Bristol" programme encourages the growth of employment growth at the city level, since it plans energy installations in houses, $75 \%$ of which are stipulated to have been built by local SMEs (Bristol City Council, 2015a). 


\subsection{Energy's impact on resilience in cities}

Cities' ability to absorb, recover (or bounce back) and adapt to and be prepared for the past and future impact of economic, environmental and social shock or chronic pressure helps promote sustainable development, well-being and inclusive growth (OECD, 2015a). Energy production is a fundamental element in this mix. This section assesses how energy affects urban resilience from the social, environmental, economic and institutional perspectives, as summarised in Table 5. These four areas are the drivers of resilience identified by the OECD 2014 Ministerial Council, and serve as the fundamental dimensions for assessing resilience (OECD, 2014a).

Table 5. The impact of energy on resilience in cities

\begin{tabular}{|c|c|}
\hline Economy & $\begin{array}{l}\text { Energy price fluctuations } \\
-\quad \text { Energy prices affect households. } \\
\text { - Energy prices affect industries. } \\
\text { Maintenance and updating of energy infrastructure } \\
\text { - Costs of maintenance and updating of existing energy infrastructure }\end{array}$ \\
\hline Environment & $\begin{array}{l}\text { GHG emissions } \\
\text { - GHG emissions influence climate change. } \\
\text { - Energy is the largest contributor to GHG emissions. } \\
\text { Heat emissions } \\
\text { - Heat due to energy consumption in cities contributes to UHI. } \\
\text { - UHI affect human health, ecosystem and energy demand. } \\
\text { Air pollutant emissions } \\
\text { - SOx and NOx are emitted by burning fossil fuels. }\end{array}$ \\
\hline Society & $\begin{array}{l}\text { Disruptions of energy supply by disasters and accidents } \\
\text { - Millions of people lose energy supply. } \\
\text { Wider regional and global effects through supply chains } \\
\text { Wionsion of service }\end{array}$ \\
\hline Institution & $\begin{array}{l}\text { Energy governance is affected by various factors } \\
\text { - Type of energy sources } \\
\text { - Relevant technologies } \\
\text { Local energy management including energy autonomous and self-sufficient emerges. }\end{array}$ \\
\hline
\end{tabular}

\subsubsection{Energy's impact on resilient urban economies}

Trends in energy prices

Most OECD countries depend on energy imported from other countries to a greater or lesser extent (Figure 8), making them more or less vulnerable to variations in energy prices. This suggests that cities' economic resilience is affected by external factors and market conditions. Total energy prices are fluctuating and basically trending upward recently in OECD countries, with a few exceptions, including just after the financial crisis of 2008 and the recent fall driven by the drop on oil prices. Energy prices are more volatile than prices of non-energy and non-food items, as can be seen in Figure 9. Consumer prices for energy significantly dropped in 2009 by $-10.6 \%$ compared to the previous year; grew until 2014 at a slower pace each year; and experienced a fall in 2015 again by $10.6 \%$ compared to their 2014 level. Core inflation -which measures the change in prices paid by urban consumers for a basket of goods and services excluding energy and food items-, is more stable: prices excluding energy and food items have grown at an average pace of $1.6 \%$ per year since 2010 . High volatility in energy prices triggers instability in urban economies through different channels, including changes in production costs. Fluctuations in energy prices affect countries and cities 
depending on the type and amount of energy they consume, import and export. For example, a rise in energy prices causes an outflow of wealth from energy-importing areas, which experience adverse effects on corporate profits and pressure on household budgets. By contrast, a rise in energy prices brings revenue to energy-exporting areas and improves their economic situation in the short term (METI, 2010).

Figure 8. Energy dependency of OECD countries (2013)

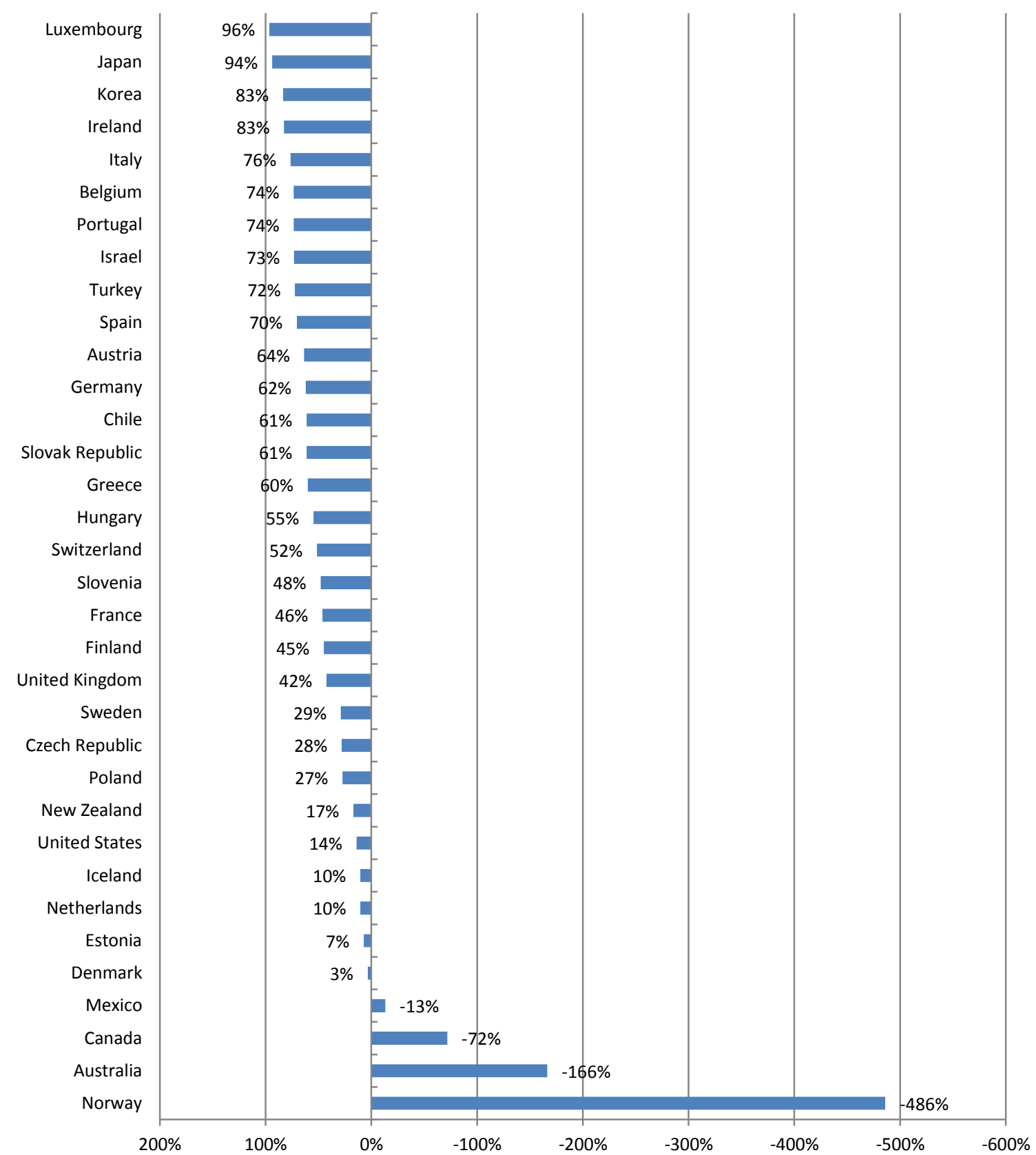

Note: Energy dependency is calculated at $100 \%$ minus energy self-sufficiency. Energy self-sufficiency is based on the data in OECD (2015c).

Source: Based on data from OECD (2015c), "Energy Balances of OECD Countries 2015", OECD Publishing, Paris, http://dx.doi.org/10.1787/energy bal oecd-2015-en. 
Figure 9. Growth in consumer prices: energy and non-energy items

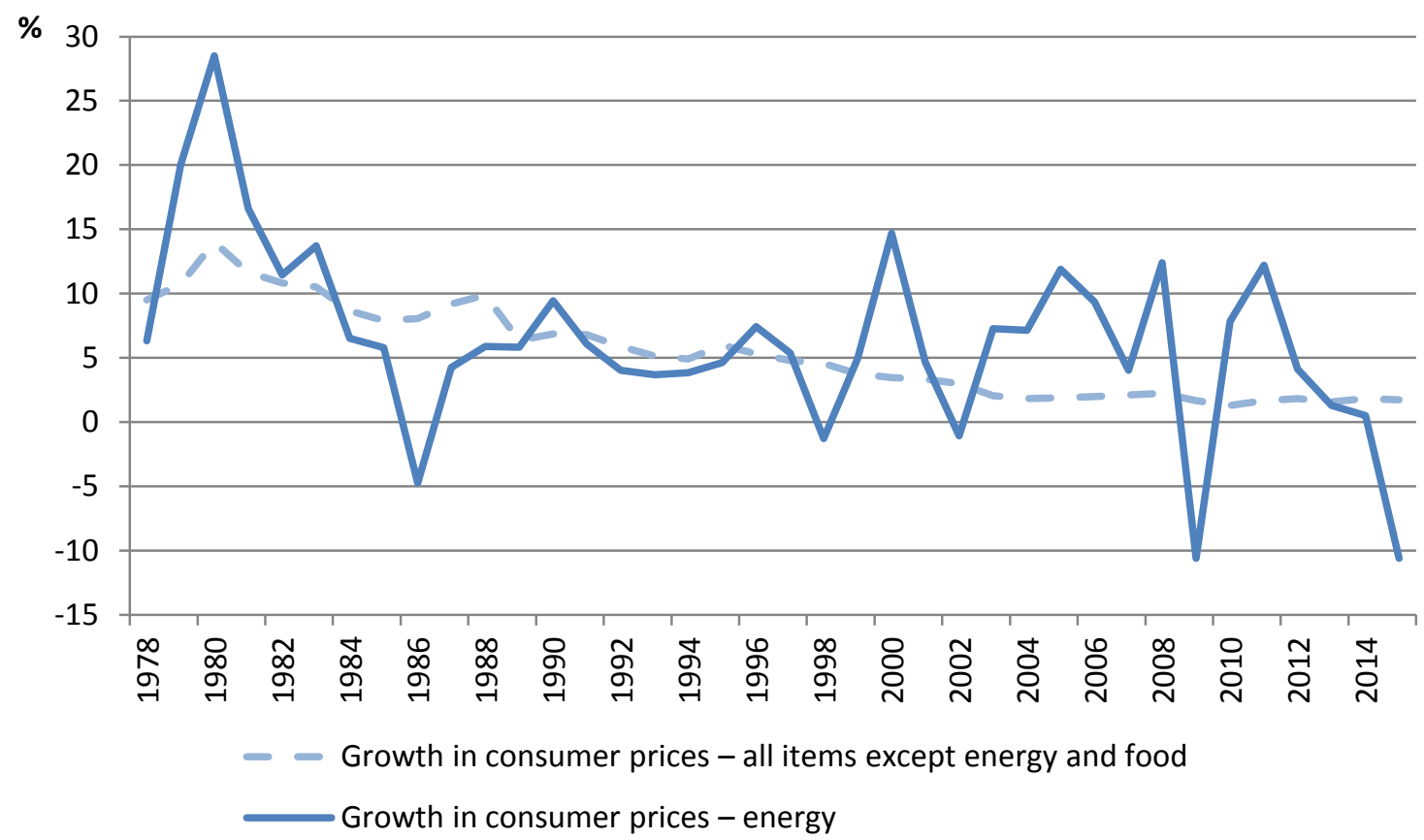

Source: Based on data from OECD (2015e), “OECD.Stat”, OECD, Paris, http://stats.oecd.org/ (accessed 3 December 2015).

\section{Energy prices and households}

Availability of energy is one of the fundamental elements in the daily life of citizens. Issues in energy prices are pivotal, in that they affect whether households can afford energy services. This is true of developed as well as developing countries. For example, approximately $10 \%$ of the population in the EU were not able to keep their homes sufficiently warm in 2014. Lower-income households suffer from more severe situations, since approximately $23 \%$ of the population of below $60 \%$ of median equivalised income are not able to keep their homes sufficiently warm. Among the OECD countries, Greece, Portugal and Italy especially face a high incidence of fuel poverty (Figure 10). ${ }^{1}$

Higher end-use energy prices also directly depress households' disposable income, lowering their purchasing power, their spending on other goods and services, as well as their level of welfare (Freund and Wallich, 1995; Congress of the United States, 2006). The size of this effect is specific to each household and depends on the percentage of its budget dedicated to energy, and on the degree of substitutability for different energy products (Freund and Wallich; 1995). After the energy crisis in 2003, the Congressional Budget Office showed that in the United States, real household income grew more slowly than if energy prices had not soared (Congress of the United States, 2006). This effect was particularly due to the rise in consumer price inflation that slowed down the economy. A rise in energy prices may also have implications for the poverty level of a population. For instance, because

\footnotetext{
${ }^{1}$ Fuel poverty or energy poverty is described as the situation of people who lack access to an adequate, affordable and reliable energy supply. It reflects the non-affordability of energy supplies and is a critical dimension of sustainable development (OECD, 2011; OECD, 2014b).
} 
of the surge in gas prices, the number of people who had difficulty paying for housing loans increased in 2007 in the United States, setting off the global financial crisis (Sexton, Wu and Zilberman, 2012).

Consequences on the level on inequality are also noteworthy. Poorer individuals are more likely to be affected by a rise in energy prices, as the share of their income devoted to energy is proportionately higher than that of wealthier people (Department of Energy \& Climate Change, UK, 2014). For example, energy expenditure represent a larger share of low-income households' budgets by comparison with that of higher-income households in the United States (American Coalition for Clean Coal Electricity, 2014). The same is true in the United Kingdom, where energy accounted for $16 \%$ of low-income households' budget, as compared to only 3\% for richer households in 2011 (Institute for Fiscal Studies, 2013). This suggests that the energy prices can affect poverty in general, as well as simply energy poverty.

Quite apart from increases in their expenses on energy, households can also be harmed indirectly by the expansion in energy prices paid by industries. Diminished demand, coupled with higher costs of production, raises the price of goods and services and hence households' cost of living (Renewable Energy Foundation, 2014). For the same reason, after the 2003 energy crisis in the United States, the growth in real wages and in employment slowed, directly affecting households' living conditions (Congress of the United States, 2006). 
Figure 10. Inability to keep household sufficiently warm (2014)

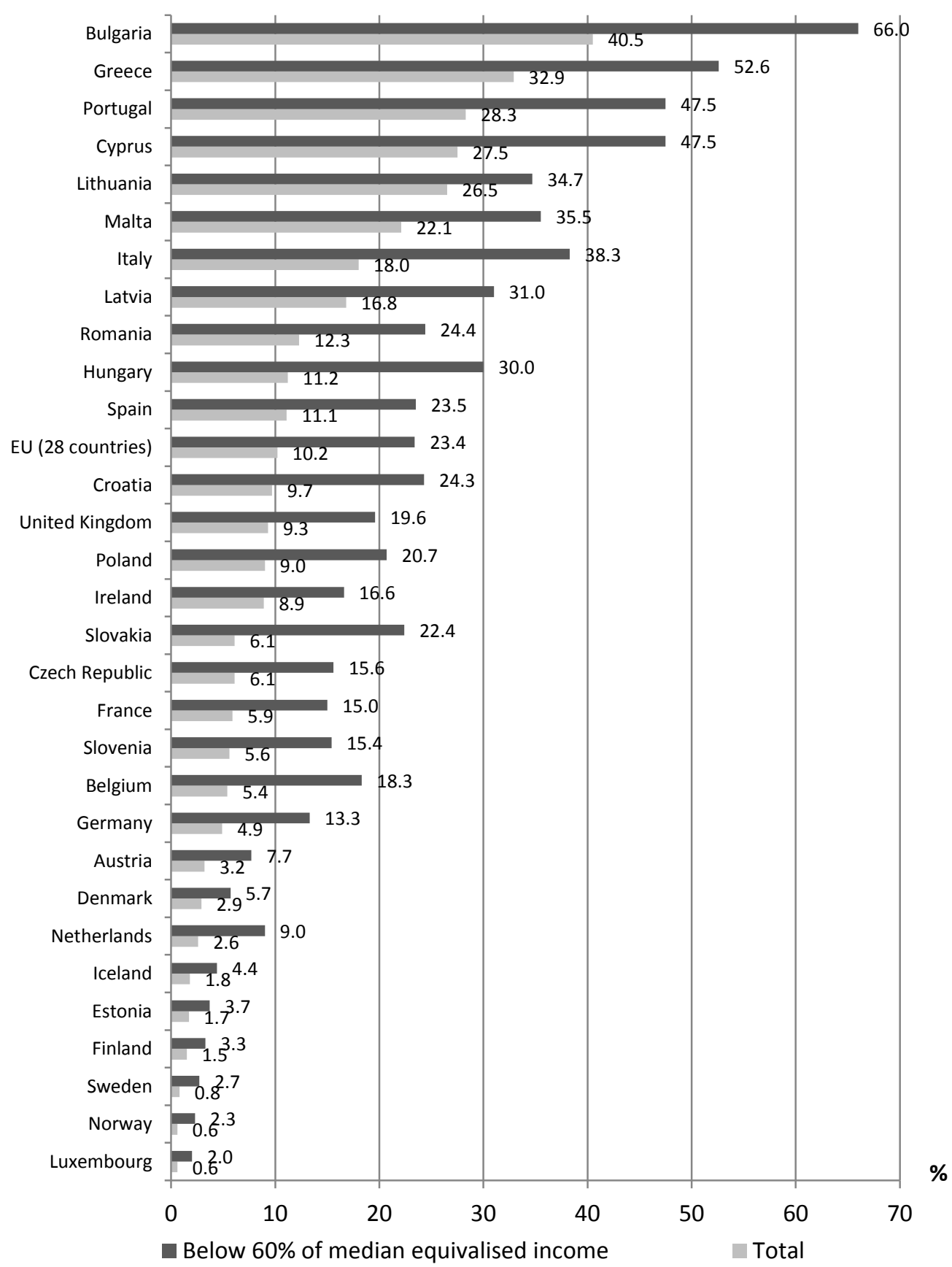

Note by Turkey:

The information in this document with reference to "Cyprus" relates to the southern part of the Island. There is no single authority representing both Turkish and Greek Cypriot people on the Island. Turkey recognises the Turkish Republic of Northern Cyprus (TRNC). Until a lasting and equitable solution is found within the context of the United Nations, Turkey shall preserve its position concerning the "Cyprus issue".

Note by all the European Union Member States of the OECD and the European Union:

The Republic of Cyprus is recognised by all members of the United Nations with the exception of Turkey. The information in this document relates to the area under the effective control of the Government of the Republic of Cyprus.

Source: Based on data from European Commission (2015b), "Eurostat", European Commission, Luxembourg, http://appsso.eurostat.ec.europa.eu/nui/setupDownloads.do (accessed 16 December 2015). 


\section{Energy prices and industries}

Energy is indispensable for industry, and fluctuations in energy prices affect industries by changing the cost of their activities, including product manufacturing and business operations. The Congressional Budget Office estimated that U.S. firms' profits would have been slightly higher in the period following the 2003 crisis had energy prices not risen (Congress of the United States, 2006). The impact of energy prices differs among the industries and companies. Energy costs of production are primarily determined by two factors: they rise with energy prices, but can be mitigated by efficiency improvements, as measured by changes in energy intensity (European Commission, 2014a). The competitiveness of energy-intensive industries, including the chemicals, cement, basic metals, aluminium, pulp and paper, and steel industries, is likely to be more severely affected by rises in energy end-use prices than other industries (European Commission, 2014a).

Fluctuations in energy prices are transmitted through firms' investment expenditures. These are affected on two fronts: first, increases in energy prices that raise the marginal cost of production; and second, reduced demand for firms' output, as consumer expenditures fall in response to rising energy prices. Fluctuations in energy prices can create uncertainty about future energy prices, causing firms to postpone irreversible investment decisions. When energy prices increase, reduced consumer demand and higher energy costs will cut firms' investment expenditures. When energy prices decrease, increased consumer demand and lower costs will increase in investment expenditures (Kilian, 2007). An increase in energy prices can depress households' purchasing power in the countries and cities that are more energy-dependent. Higher energy prices reduce the economic resilience of both cities and countries.

\section{Maintenance and updating of energy infrastructure}

Energy infrastructure, including transmission lines and power plants, entails costly maintenance and updating that can put pressure on an economy. This includes the ageing of energy infrastructure in EU countries that is not able to support future energy demands, to ensure security of supply or to support large-scale deployment of energy from renewable sources. The cost of upgrading of existing infrastructure and development of new energy transmission infrastructure is estimated to be around EUR 140 billion in electricity and at least EUR 70 billion in gas (European Commission, 2015a; INEA, 2015).

The United States also faces similar issues. Many of its power delivery systems were built on technology developed over 50 years ago, and can only respond to disturbances at the speed permitted by the technology of that period. This limitation increases the vulnerability of the power system to outages that can spread quickly and impact whole regions (US Department of Energy, 2010). The ageing grid requires heavy investment in grid infrastructure. Other technological solutions should be explored to reduce the burden of reinvesting in energy infrastructure in the long run. For example, smart grid technology, including advanced ICT, advanced metering solutions, and technologies, devices, and services that access and leverage energy usage and information are expected to contribute to these issues. Many of these technologies promise to pay for themselves in operational improvements and energy savings (US Executive Office of the President, 2011). 


\subsubsection{Energy's impact on a resilient environment in cities}

An urban area's natural environment, composed of air, water, flora, fauna and green space, can have a significant impact on resilience, not only with respect to the ecosystem, but also with respect to social factors, such as health and social infrastructure (OECD, 2015a). As cities emit GHG, heat and air pollutants in relation to their energy consumption, they help to cause negative effects, even as they suffer from them.

\section{GHG emissions}

Among human activities, energy use is the largest contributor of GHG emissions (Figure 11). It is likely that more than half of the observed increase in global average surface temperature from 1951 to 2010 was caused by the anthropogenic increase in GHG concentrations and other anthropogenic causes (IPCC, 2013). It is likely that global mean sea level has accelerated since the early 1900s (IPCC, 2013), and sea level rise during the latter half of the 20th century is likely to be caused by anthropogenic forcing, resulting in thermal expansion from ocean warming and loss of glacier mass (IPCC, 2007). Sea level rise raises the maximum wave heights of high tides and can increase the risks and losses of floods. Seashore cities are likely to be required to prepare for floods and spend on developing disaster management facilities. According to the estimates of one study, average global flood losses in 2005 are estimated to have been approximately USD 6 billion per year, increasing to USD 52 billion with socio-economic change alone, and with continuing climate change and subsidence, to increase to USD 1 trillion or more per year by 2050 (Hallegatte et al., 2013).

Energy dominates the trend in $\mathrm{CO}_{2}$ emissions, accounting for $82 \%$ of the global total and for $95 \%$ of OECD total $\mathrm{CO}_{2}$ emissions in 2010 (IEA, 2014a). A certain correlation between GHG emissions per capita and share of urban population can be found in the OECD countries (Figure 12). To ensure economic growth, while reducing GHG emissions, including $\mathrm{CO}_{2}$, is the crux of urban resilience issues. As GHG emissions are projected to increase in the OECD countries (Figure 13), increasing these issues in the future is a major concern. Conditions in cities affect energy consumption, as can be seen in the relations between population density and urban $\mathrm{CO}_{2}$ emissions per capita (Figure 14). Energy management is thus a vital element in evaluating urban policies.

Figure 11. GHG emissions by human activities

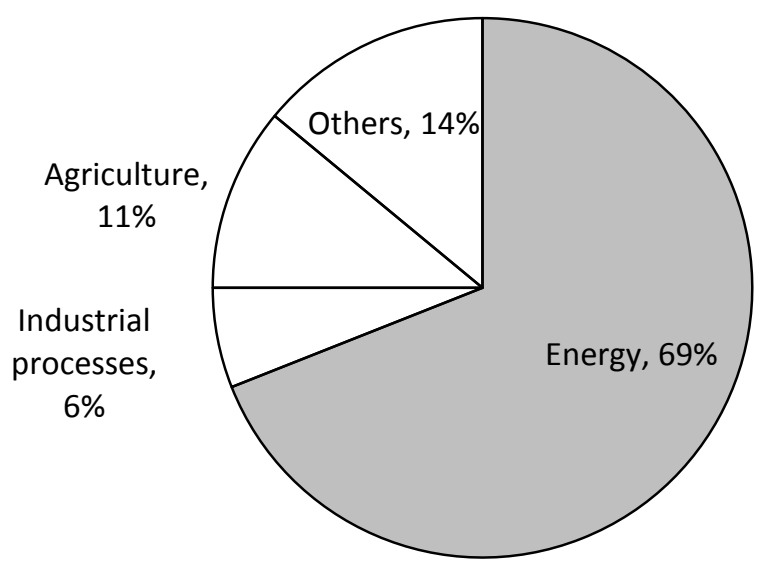

Source: Based on data from IEA (2014), " $\mathrm{CO}_{2}$ Emissions from Fuel Combustion 2014", IEA, Paris, http://dx.doi.org/10.1787/co2 fuel-2014-en. 
Figure 12. Urban population share and GHG emissions per capita (2010)

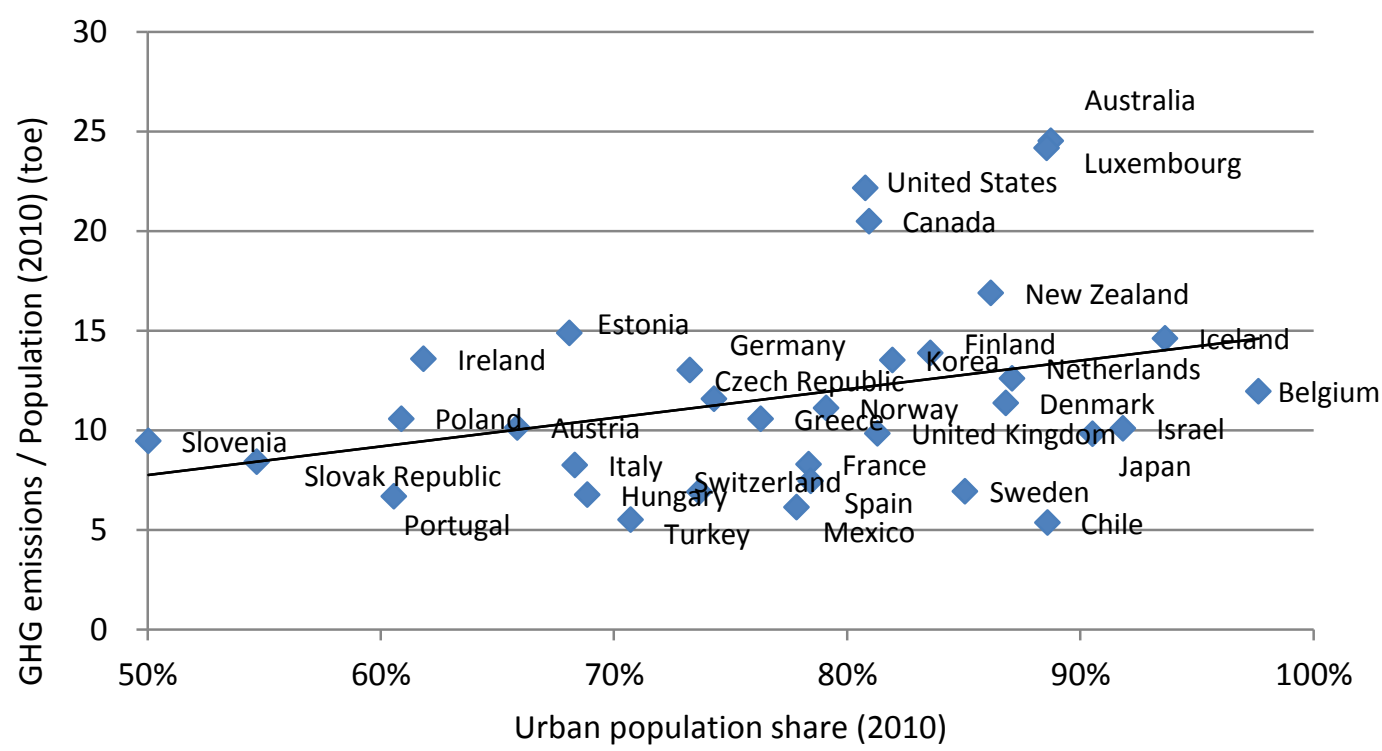

Note: Urban population share is from the United Nations (2014), whose estimates are taken from the most recently available census or official population estimate of each country, and follows the definition of "urban" population used in each country.

Source: Based on data from OECD (2015e), "OECD.Stat", OECD, Paris, available at: http://stats.oecd.org/; United Nations (2014), "World Urbanization Prospects: The 2014 Revision", http://esa.un.org/unpd/wup/CD-ROM/ (accessed 3 December 2015).

Figure 13. GHG emissions in the OECD AI, baseline, 2010-2050

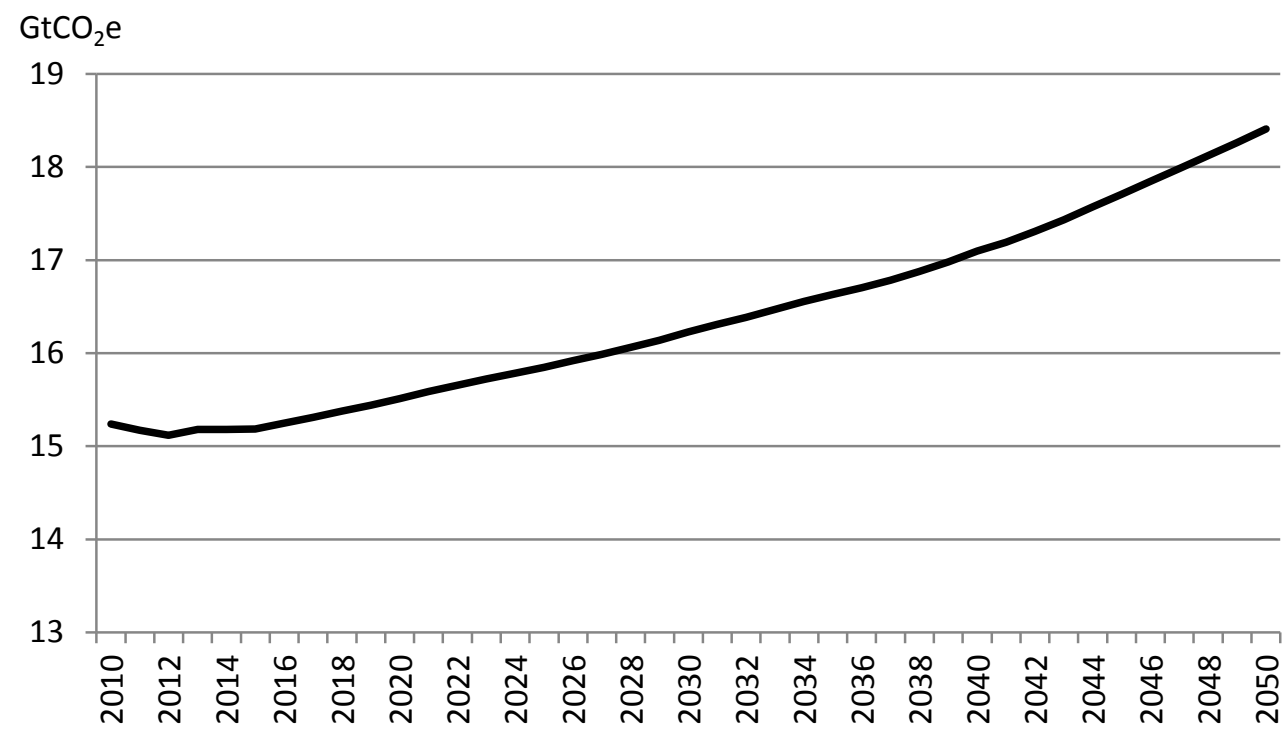

Note: "OECD Al" stands for the group of OECD countries that are also part of Annex I of the Kyoto Protocol. $\mathrm{GtCO}_{2} \mathrm{e}=\mathrm{Giga}$ tonnes of $\mathrm{CO}_{2}$ equivalent.

Source: Based on data from OECD (2012d), "OECD Environmental Outlook to 2050", OECD Publishing, Paris, http://dx.doi.org/10.1787/888932570468. 
Figure 14. Population density and $\mathrm{CO}_{2}$ emissions per capita in large metropolitan areas

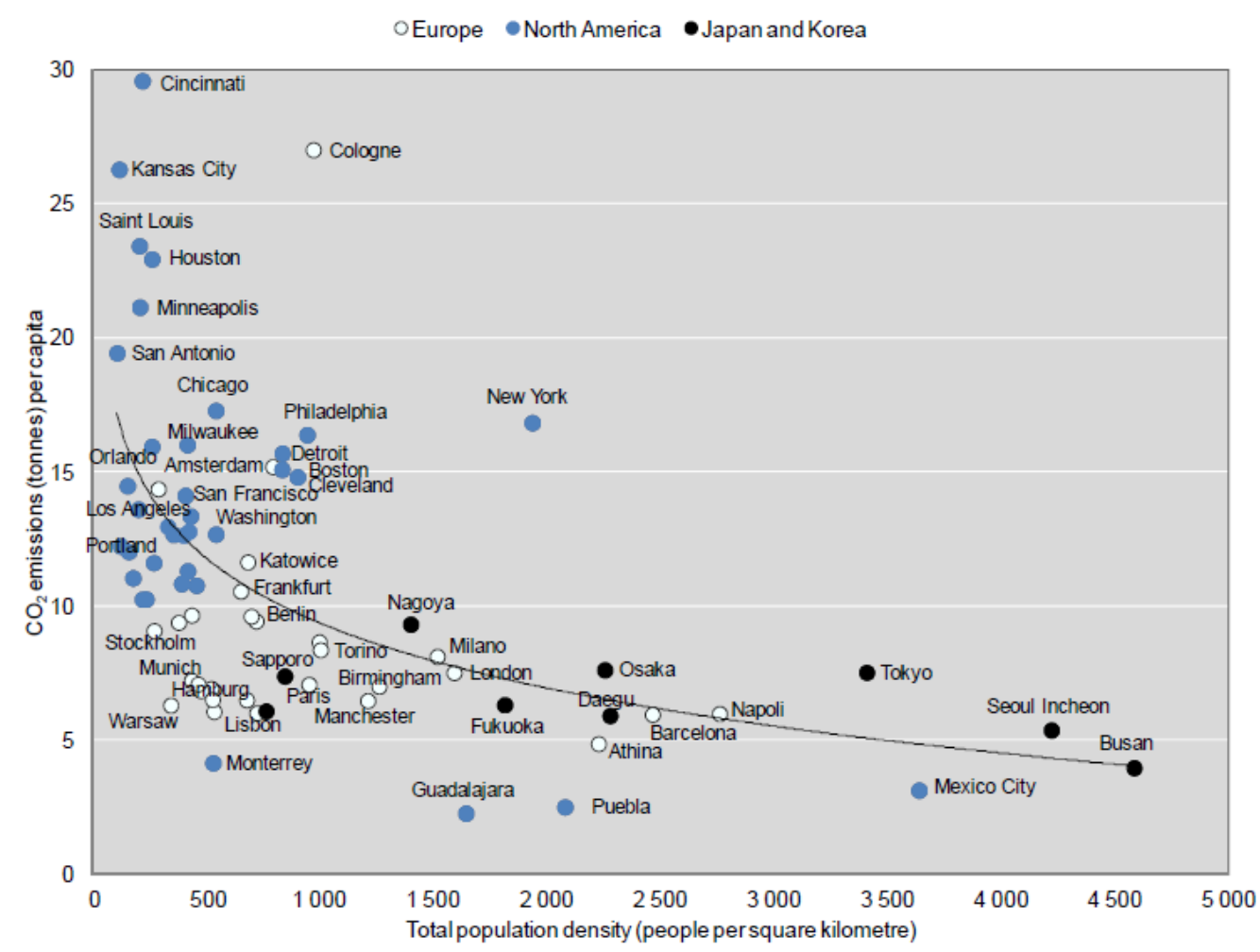

Source: OECD (2012b), "Redefining "Urban": A New Way to Measure Metropolitan Areas", OECD Publishing, Paris, http://dx.doi.org/10.1787/9789264174108-en

\section{Heat emissions}

The "urban heat island" effect (UHI) is a phenomenon in which urban regions experience warmer temperatures than their rural surroundings (US Environmental Protection Agency, 2008). A survey shows that global mean annual temperatures in cities rose more than mean annual temperature on the ground (Figure 15). Artificial heat is exhausted in cities, due to energy consumption in buildings, housing, industries and transport, and contributes to the urban heat island effect. Physical environment of cities also contributes to UHI. For instance, land in cities tends to be covered with artificial materials including asphalt and concrete, making it more difficult to lower the temperature by evaporation than on natural ground surfaces. Many buildings in cities absorb heat from sunshine in the daytime and emit heat at night, keeping the temperature in cities higher at night. Groups of large buildings can prevent the circulation of cool breezes and also contribute to keeping urban temperatures higher. Waste heat produced by urban activities, including the air conditioning of buildings and transport, also contributes to UHI.

UHI has impacts on human health, ecological systems and energy demand in cities. Higher temperatures, especially in summer, can cause heatstroke among urban residents. For instance, numbers of heatstroke patients have multiplied ten times from 2000 to 2015 in Tokyo, as the mean temperature has increased (Tokyo Metropolitan Government, 2014). Smog by photochemical reactions of pollutants in the air is more likely to be created by higher temperatures. The incidence of smog increases by $5 \%$ for every $1{ }^{\circ} \mathrm{C}$ the temperature rises above $22^{\circ} \mathrm{C}$ in Los Angeles (Akbari, 2005). Higher temperatures can affect the ecological system, including changes of growing season and habitat 
of species. UHI can increase the energy demand of cities. According to one research study, peak urban electric demand rises by $2 \%$ to $4 \%$ for each $1 \mathrm{~K}$ rise in daily maximum temperature above a threshold of $15-20^{\circ} \mathrm{C}$, and the additional air-conditioning use caused by this urban air temperature increase is responsible for 5\% to $10 \%$ of urban peak electric demand (Akbari, 2005). On the contrary, UHI can reduce energy demand in several cities, because the amount of reduction of gas and oil demand in winter is greater than the increase of electricity demand in summer (MOE, 2010).

Figure 15. Mean annual temperature in Tokyo, New York, Paris and Berlin, and global mean annual temperature anomaly on the ground

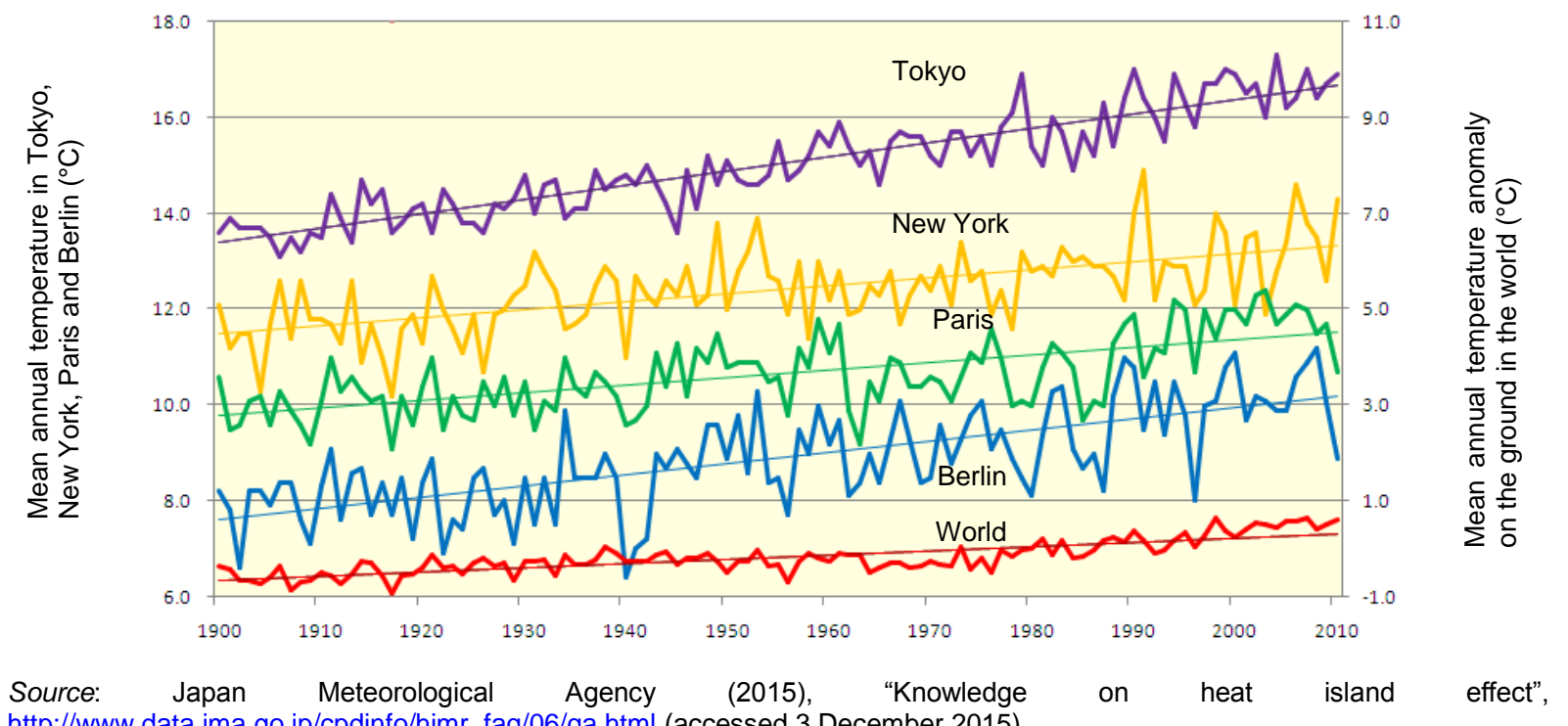

\section{Emissions of air pollutants}

Air pollutants are caused by energy use in cities, which have an impact on resilience. Sulphur oxide and nitrogen oxide are emitted by the burning of fossil fuels, affecting the environment, with acid rains and health hazards. Incomplete combustion of fossil fuels produces carbon monoxide and causes photochemical smog by sulphur oxide and nitrogen oxide. Furthermore, particulate matter residue of sulphur oxide and nitrogen oxide contained in fossil fuels can cause health damage, including respiratory diseases and cardiovascular diseases (US Environmental Protection Agency, n.d.).

Particles of less than approximately 2.5 micrometres $\left(\mathrm{PM}_{2.5}\right)$ have a worse effect on health than $\mathrm{PM}_{10}$. The World Health Organization (WHO) provides air quality guidelines for particulate matter. The threshold of annual mean concentration of $\mathrm{PM}_{2.5}$ is below $10 \mu \mathrm{g} / \mathrm{m}^{3}$. Interim targets for targetsetting in each country are also provided, and the thresholds are $35 \mu \mathrm{g} / \mathrm{m}^{3}, 25 \mu \mathrm{g} / \mathrm{m}^{3}$ and $15 \mu \mathrm{g} / \mathrm{m}^{3}$. For instance, the figures for the US are $15 \mu \mathrm{g} / \mathrm{m}^{3}$, for the EU $25 \mu \mathrm{g} / \mathrm{m}^{3}$ and for Japan $15 \mu \mathrm{g} / \mathrm{m}^{3}$. In the OECD's 275 metropolitan areas, only $9 \%$ of the population enjoys air with lower than $10 \mu \mathrm{g} / \mathrm{m}^{3}$, which meets the WHO air quality guidelines (Figure 16). 
Figure 16. Exposure of population to PM2.5 in the 275 OECD metropolitan areas

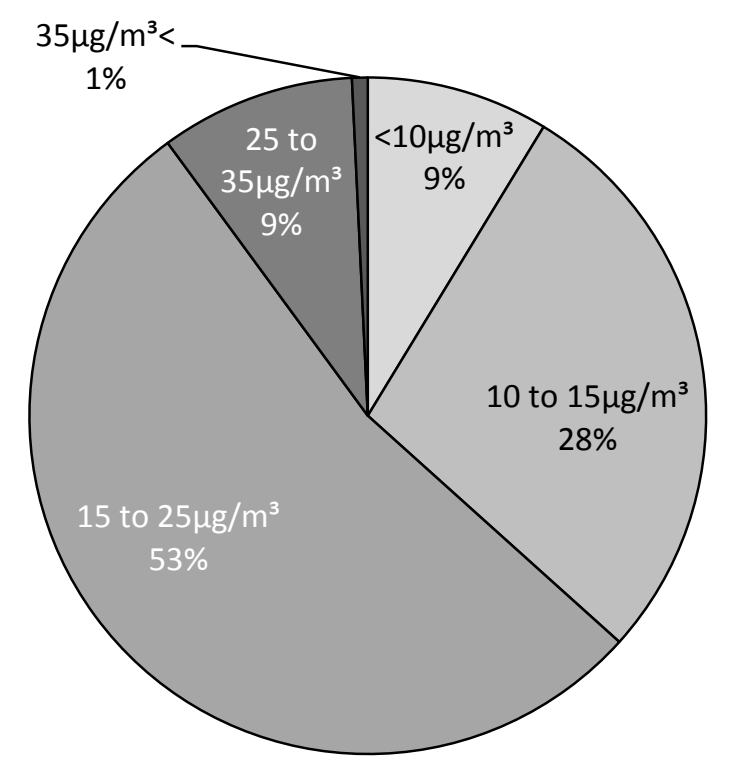

Source: Based on data from OECD (2012c), "The OECD Metropolitan Areas Database", OECD, Paris, http://measuringurban.oecd.org/\#story=0 (accessed 3 December 2015).

\subsubsection{Energy's impact on resilient society in cities}

A stable energy supply in cities is crucial for urban social resilience. Extreme events, including natural disasters and accidents, have major effects on urban energy supply, as experience has shown. As for the disruptions of energy supply to the cities from disasters, OECD countries have suffered severe damages from natural disasters, and the occurrence and the damage caused by the disasters both seem to have increased recently (Figure 17). Natural disasters can be the main causes of the disruption of the energy supply (Figure 18). Nearly half of the blackouts in the US were the result of natural causes, including earthquakes, tornados, hurricanes or tropical storms, ice storms, lightning, wind or rain storms and other cold weather. The disruption of the energy supply by natural disasters can affect a larger number of customers than other events including equipment failure and operator error (Figure 19). 
Figure 17. Number of annual disasters and economic damage due to natural disasters in OECD countries

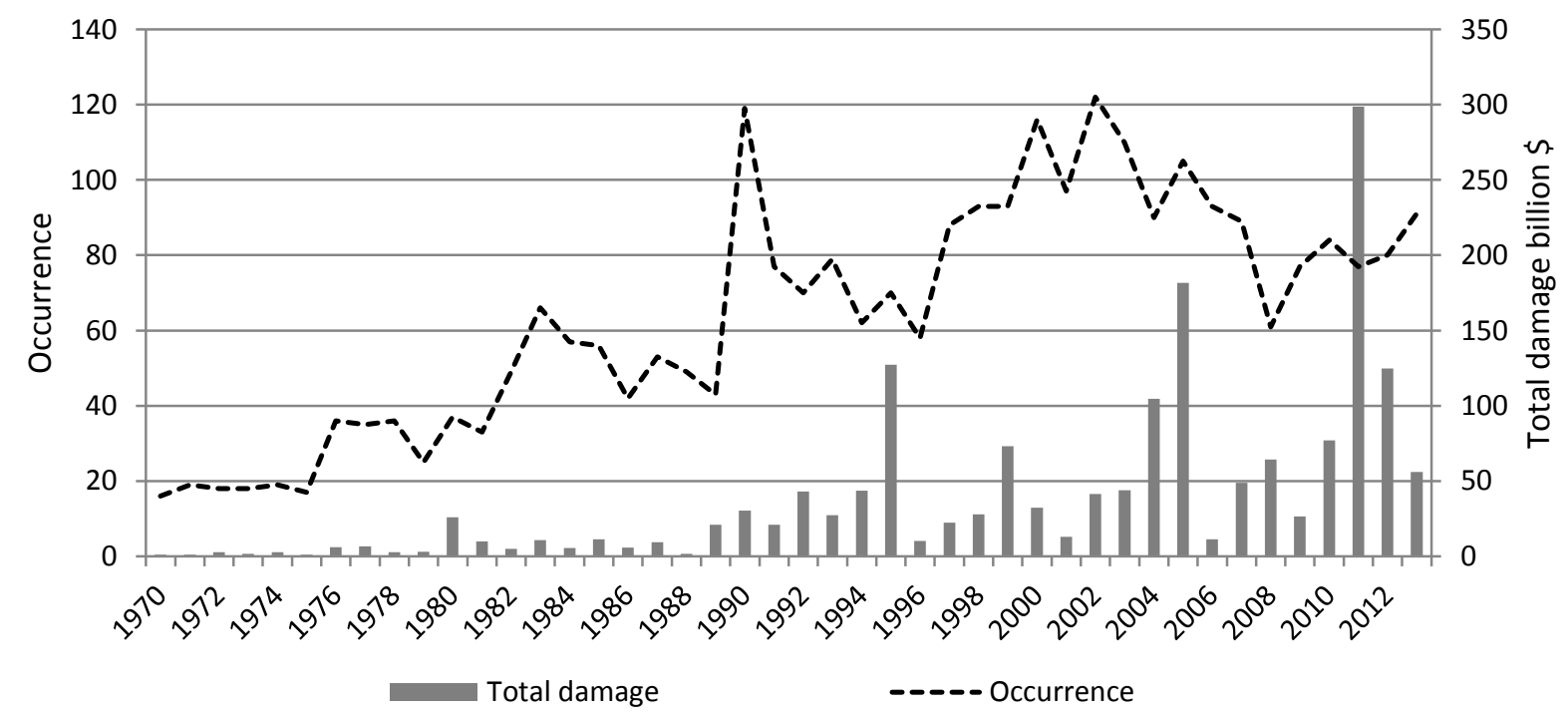

Source: Based on data from CRED (2009), “EM-DAT Database”, CRED, Brussels, http://www.emdat.be/database

Figure 18. Blackout-initiating events, United States (\% of all events from 1984 to 2006)

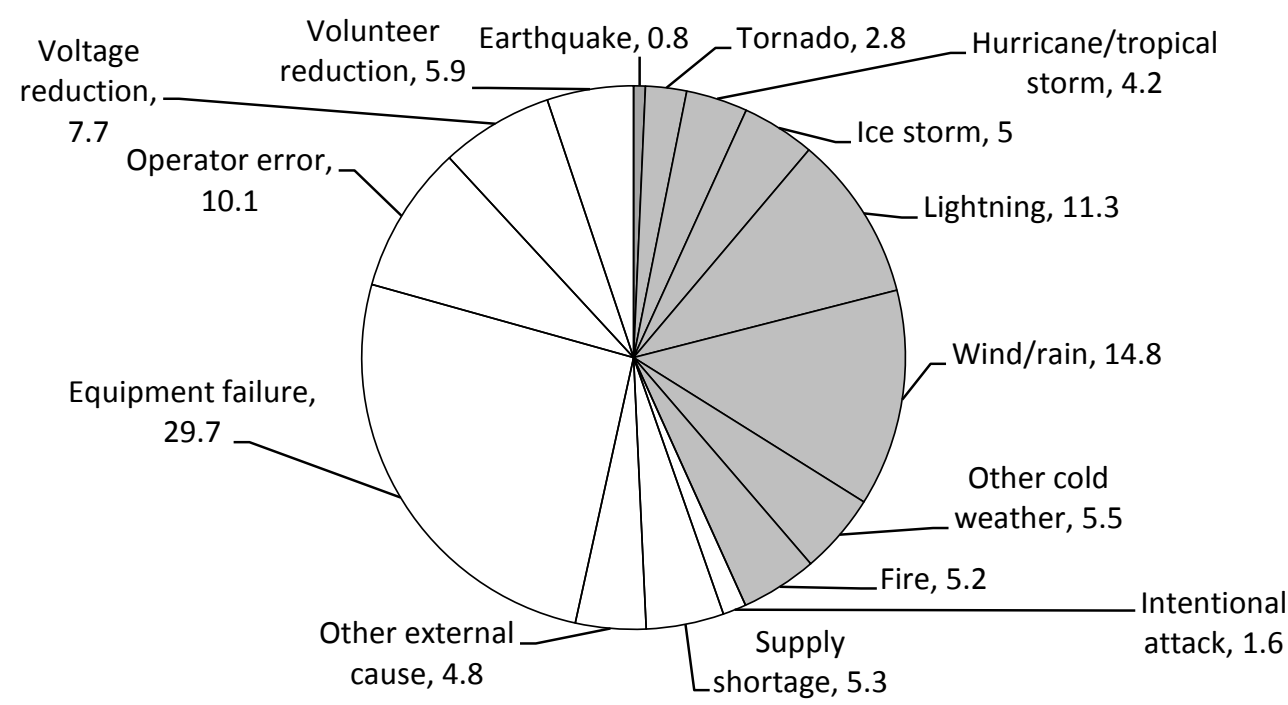

Note: The totals are not $100 \%$ because some events belong to multiple initiating-event categories.

Source: Based on data from Hines et al. (2009), "Trends in the History of Large Blackouts in the United States", IEEE, New York, available at: http://www.uvm.edu/ phines/publications/2008/Hines 2008 blackouts.pdf. 
Figure 19. Blackout-initiating events and mean size in customers, US (1984-2006)

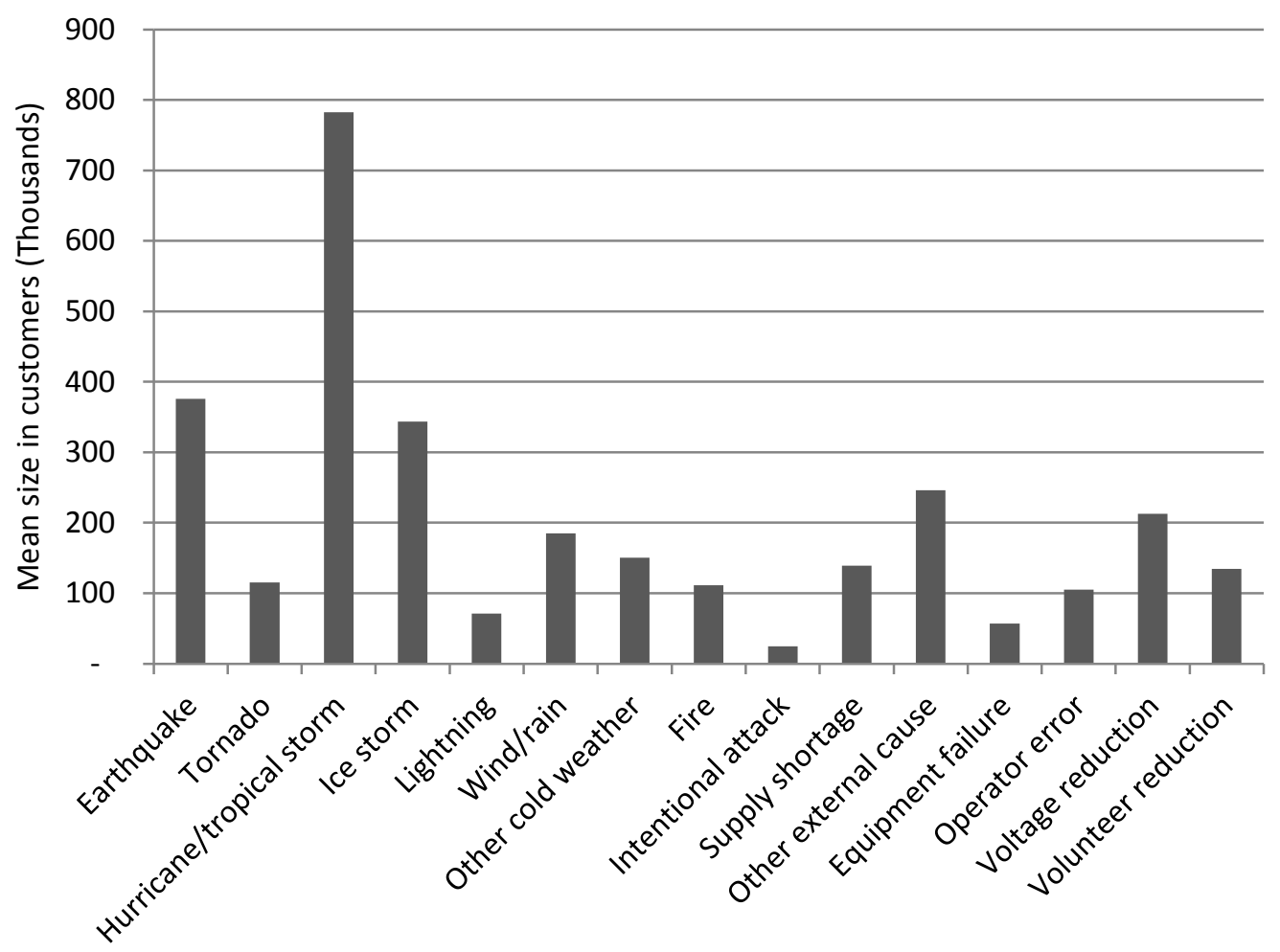

Source: Based on data from Hines et al. (2009), "Trends in the History of Large Blackouts in the United States", IEEE, New York, available at: http://www.uvm.edu/ phines/publications/2008/Hines 2008 blackouts.pdf.

The disruption caused by the Great East Japan Earthquake in 2011, for example, caused extensive social damages. Eight million households in eastern Japan lost electricity supply, and a week passed before most areas recovered. Its effects were long-lasting, after rolling blackouts were implemented to respond to long-term energy shortages. In 2012, Hurricane Sandy devastated the Northeastern seaboard of the United States and neighbouring countries. More than eight million customers in 21 states lost electricity, and the New York Stock Exchange closed for two days after wide area power outages caused by the storm.

As for the disruptions of energy supply by accidents, the Northeast blackout of 2003 had a major impact in both the United States and in Canada. The blackout affected 55 million people and resulted in economic damages in the billions of US dollars, a drop in GDP and manufacturing shipments, and the loss of working hours. In Europe, Blackout in November 2006 interrupted the power supply for more than 15 million European households.

Experience of energy disruptions caused by natural disasters or accidents (Table 6) shows that energy supply can be unstable and disrupted at the same time in the wide area across regional or national borders. The influence of energy disruptions is not limited to the stricken cities but spread over a wide area, given that economic activity and electricity grids are interconnected. Such energy disruptions and their impact need to be considered in helping make cities resilient. 
Table 6. Disruptions of energy supply due to natural disasters and accidents

\begin{tabular}{|c|c|c|}
\hline Disasters and accidents & Date of occurrence & Impacts \\
\hline $\begin{array}{l}\text { The Great East Japan } \\
\text { Earthquake } \\
\text { (Japan) }\end{array}$ & 11 March 2011 & $\begin{array}{l}\text { - } 8 \text { million households in eastern Japan affected } \\
\text { - About a week required before recovery in most } \\
\text { areas } \\
\text { - Rolling blackouts were implemented to respond to } \\
\text { long-term energy shortages. }\end{array}$ \\
\hline $\begin{array}{l}\text { Hurricane Sandy } \\
\text { (North America and } \\
\text { Caribbean countries } \\
\text { including US and Canada) }\end{array}$ & 29 October 2012 & $\begin{array}{l}\text { - More than } 8 \text { million customers in } 21 \text { states lost } \\
\text { electricity. } \\
\text { - The New York Stock Exchange closed for } 2 \text { days. } \\
\text { - Some of the nuclear power units in New York and } \\
\text { New Jersey shut down. }\end{array}$ \\
\hline $\begin{array}{l}\text { The Northeast blackout of } \\
2003 \\
\text { (US and Canada) }\end{array}$ & 14 August 2003 & $\begin{array}{l}\text { - Fifty million people across the U.S.-Canadian } \\
\text { border were affected. } \\
\text { - The blackout lasted four days. } \\
\text { - USD } 4 \text { billion to USD } 10 \text { billion costs in the US; GDP } \\
\text { in Canada for August down by } 0.7 \% \text {, } \\
\text { manufacturing shipments in Ontario down CAD } \\
2.3 \text { billion }\end{array}$ \\
\hline $\begin{array}{l}\text { Blackout in Europe in } \\
\text { November } 2006 \\
\text { (European countries } \\
\text { including France, Italy, } \\
\text { Germany, Spain, Portugal, } \\
\text { the Netherlands, Belgium, } \\
\text { Switzerland, Austria, } \\
\text { Hungary and Slovenia ) }\end{array}$ & 4 November 2006 & $\begin{array}{l}\text { - } 15 \text { million households across Europe affected } \\
\text { - Union for the Co-ordination of Transmission of } \\
\text { Electricity (UCTE) grid affected by an incident } \\
\text { originating in the transmission grid in northern } \\
\text { Germany }\end{array}$ \\
\hline
\end{tabular}




\section{Box 3. Disruptions of the energy supply in the Great East Japan Earthquake}

The Great East Japan Earthquake on 11 March 2011 caused tremendous human suffering, with a death toll of 15893 and 2573 missing people in 12 prefectures (Cabinet office, 2015). The estimated economic damage to social infrastructure, including buildings, water supply, sewage, river and roads, was JPY 16.9 trillion (Cabinet office, 2011a). The damages caused by the earthquake and reconstruction activities related to energy production and supply are as follows.

Generalised blackouts of electricity occurred, due to disruption of nuclear power plants and damage to thermal power plants. Immediately after the earthquake, 4.66 million households in the Tohoku electric power company area and 4.05 million households within the Tokyo electric power company area lost electricity supply. The availability of the electrical power supply was reduced by approximately $40 \%$ in the Tokyo electric power company's jurisdiction and by approximately $35 \%$ in the Tohoku electric power company jurisdiction (METI, 2012). After 14 March 2011, rolling blackouts were implemented for 10 days in total in the Tokyo electric power company area (METI, 2013). The Japanese government requested consumers of electricity to save electricity in summer and in winter to respond to these situations.

City gas production and supply facilities were damaged by the subsequent tsunami and liquefaction. Damages to supply facilities were experienced in other earthquakes, but the tsunami that followed the earthquake caused damages to energy production facilities. City gas suppliers from all over the country supported the recovery operation, and gas supplies were temporarily supplemented by mobile gas-generating facilities. Alternative gas supplies over a wide area were delivered through a natural gas pipeline substitute to the liquefied natural gas (LNG) terminal in the city of Sendai, which was expected to require around one year for recovery (METI, 2013).

Six of the nine oil refineries in the Tohoku and Kanto regions were damaged. Maintaining a stable supply of oil products was difficult because tankers could not dock at the main supply base port, and many tank trucks were damaged. Seven of the nine LPG supply bases in the Tohoku region and Ibaraki prefecture were damaged. Transport of gasoline from oil depots to service stations had been affected by damage to tank trucks and disruption of the transport network. In collaboration with related organisations and oil companies, the Japanese government responded to the urgent requests of various parties, including hospitals, police and fire authorities (METI, 2013).

\section{Extensive power failures in the Great East Japan Earthquakes, March 2011}

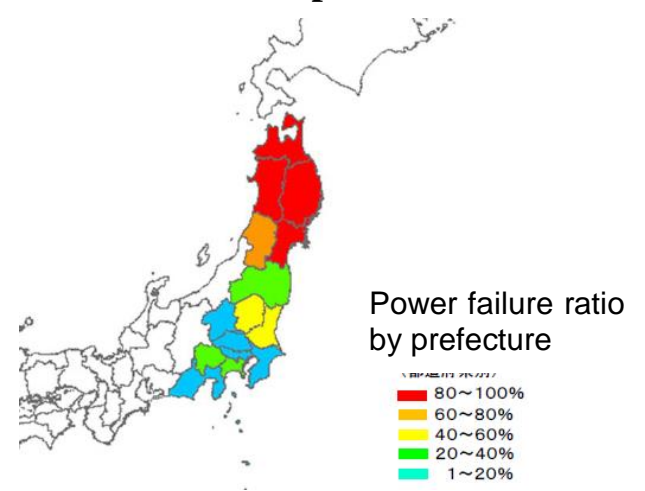

\begin{tabular}{|l|r|r|}
\hline Prefecture & $\begin{array}{l}\text { Number of blackout } \\
\text { houses }\end{array}$ & $\begin{array}{l}\text { Power failure } \\
\text { ratio }\end{array}$ \\
\hline Aomori & 900000 & $99 \%$ \\
\hline Iwate & 770000 & $95 \%$ \\
\hline Akita & 660000 & $98 \%$ \\
\hline Miyagi & 1370000 & $96 \%$ \\
\hline Yamagata & 510000 & $74 \%$ \\
\hline Fukushima & 270000 & $22 \%$ \\
\hline Kanagawa & 1277705 & $24 \%$ \\
\hline Tochigi & 567925 & $43 \%$ \\
\hline Ibaraki & 823404 & $42 \%$ \\
\hline Yamanashi & 145009 & $22 \%$ \\
\hline
\end{tabular}

Source: Japanese Committee for Technical Investigation on Countermeasures for Earthquakes and Tsunamis, Based on the Lessons Learned from the 2011 off the Pacific Coast of Tohoku Earthquake (2011), "Data on damage", Cabinet Office, Tokyo, available at: http://www.bousai.go.jp/kaigirep/chousakai/tohokukyokun/1/pdf/sub2.pdf. 


\section{Box 4. Disruptions in energy supplies after Hurricane Sandy}

Hurricane Sandy, which struck on 29 October 2012, resulted in significant damages across the East Coast of the United States and also severely affected neighbouring countries, including Canada, Haiti, Cuba, the Bahamas, the Dominican Republic and Puerto Rico. The storm caused massive damages to electricity infrastructure, with heavy economic and social costs. In the Northeastern United States on 30 October, three nuclear reactors were shut down, and two units had a reduced power capacity. A substation owned by ConEdison, New York's major electricity provider, exploded on 29 October and directly deprived 250000 people of power in Manhattan. In New York City, about 800000 households were blacked out the day after the hurricane, affecting $20 \%$ of the population of the city. The Northeast region suffered a massive power outage, leaving 8.2 million people and businesses without electricity on 30 October along the East Coast. The states of New Jersey, New York, Pennsylvania and Connecticut were the most affected in the US, with 2.6 million customers affected by the blackout in the state of New Jersey, representing $31 \%$ of the local population. The New York Stock Exchange was closed for two days. Other countries were also severely affected, with 145000 people blacked out in Canada and 70\% of customers in Jamaica left without electricity. In some areas, the blackout persisted for several days or months. In the US, $90 \%$ of power supply was restored on 8 November, but in January 2013, 8200 people were still without power.

Recovery of the electricity supply was slow, since physically damaged infrastructure had to be repaired before service could be restored. Customers with underground power lines generally recovered electricity quicker, and the expedient of burying power lines is no guarantee against risk, as demonstrated by the flood damage in the area of New York City. Despite the regulatory process that staggered recovery costs over more than a year, electricity prices were raised for consumers to cover the costs of restoration. Hurricane Sandy caused sizeable damages to refineries, oil terminals and pipelines. Because of flooding, two refineries were shut down in New Jersey in October and four were running at reduced capacity on the East Coast (US Department of Energy, 2012). This triggered significant gas shortages throughout the area. The solution adopted by the federal government was first to provide gasoline free of charge through mobile truck distribution. In response to the subsequent lines of consumers waiting for gasoline that this created, it was decided to establish odd-even rationing of gas, based on the numbers on a vehicle's licence plates.

\section{Power failures in the US caused by Hurricane Sandy, October 2012}

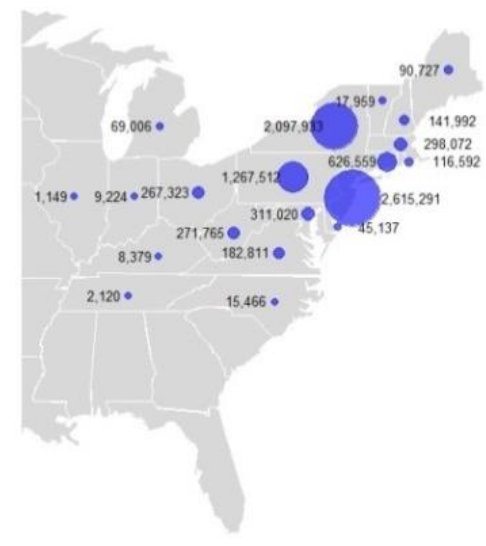

\begin{tabular}{|l|r|r|}
\hline & $\begin{array}{l}\text { Number of } \\
\text { customer outages } \\
\text { (peak) }\end{array}$ & $\begin{array}{l}\text { Percentage of } \\
\text { customers } \\
\text { without power } \\
\text { (on 30 }\end{array}$ \\
\hline New Jersey & 2615291 & $65 \%$ \\
\hline Connecticut & 626559 & $31 \%$ \\
\hline West Virginia & 271765 & $27 \%$ \\
\hline New York & 2097933 & $23 \%$ \\
\hline Rhode Island & 116592 & $23 \%$ \\
\hline New Hampshire & 141992 & $19 \%$ \\
\hline Pennsylvania & 1267512 & $19 \%$ \\
\hline
\end{tabular}

Source: Based on data from US Department of Energy (2012), Hurricane Sandy Situation Report \# 5, US Department of Energy, Washington DC, available at: http://www.oe.netl.doe.gov/docs/2012 SitRep5 Sandy 10302012 300PM v 1.pdf. 


\section{Box 5. The Northeast blackout of 2003}

North America suffered a major power blackout on 14 August 2003 that disrupted industrial activity, transport and water infrastructure for up to a week, causing damages of billions of dollars. The blackout affected eight US states (Ohio, Michigan, Pennsylvania, New York, Vermont, Massachusetts, Connecticut and New Jersey) and the Canadian province of Ontario. Some areas of the US were left without power for up to four days, and power was restored to all Ontario customers only on 22 August (Natural Resources Canada and the U.S. Department of Energy, 2006). An estimated 55 million people (45 million in the US and 10 million in Canada) were affected (Natural Resources Canada and the U.S. Department of Energy, 2006) in an area including New York City, Toronto, Detroit, Cleveland and Ottawa.

The causes of the blackout were classified into four groups in a report conducted subsequently by the U.S.-Canada Power System Outage Task Force. First, FirstEnergy and ECAR failed to anticipate and evaluate the inadequacies of FE's system, particularly with respect to voltage instability and the vulnerability of the Cleveland-Akron area. FE did not operate its system according to appropriate voltage criteria. Secondly, FirstEnergy failed to recognise the degree to which the condition of its system was deteriorating. Third, FE failed to manage adequately tree growth in its transmission rights of way. Fourth, interconnected grid's reliability organisations failed to provide effective real-time diagnostic support (US-Canada Power System Outage Task Force, 2004).

The total cost attributed to the blackout in the US was estimated at between USD 4 billion and USD 10 billion. In Canada, the gross domestic product fell 0.7\% in August, with a net loss of 18.9 million work hours, and manufacturing shipments in Ontario were down CAD 2.3 billion (Natural Resources Canada and the U.S. Department of Energy, 2006). The Ohio Manufacturers Association reported direct costs of the blackout on Ohio manufacturers to be USD 1.08 billion (more than half of the manufacturing industry was affected). The Detroit Regional Chamber assessed losses of USD 220 million in the Detroit area (ELCON, 2004). The blackout also resulted in significant nonfinancial losses, such as subway passengers stranded underground and emergency vehicles stalled in traffic because of failed traffic lights (Hines et al., 2009).

\section{Power failures caused by the Northeast blackout of 2003}

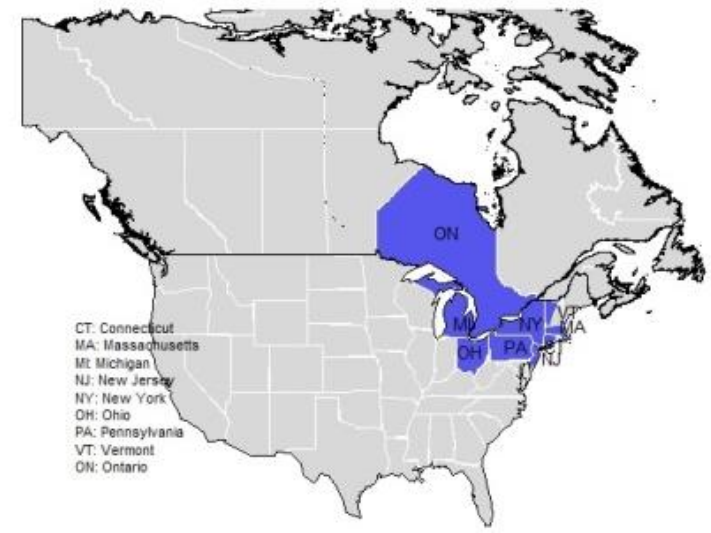

Source: Own illustration, based on data from Natural Resources Canada and the U.S. Department of Energy (2006), "Final Report on the Implementation of the Task Force Recommendations", Natural Resources Canada and US Department of Energy, Washington DC, available http://energy.gov/sites/prod/files/oeprod/DocumentsandMedia/BlackoutFinallmplementationReport\%282\%29.pdf. 


\section{Box 6. Blackout of November 2006 in Europe}

Europe's electricity network is highly interconnected across the borders, which can cause wide area blackouts across European countries. On 4 November 2006, Europe experienced an interruption of power supplies to more than 15 million European households. The Union for the Co-ordination of Transmission of Electricity (UCTE) interconnected grid was affected by a serious incident originating in the transmission grid in northern Germany. There were significant East-West power flows as a result of international power trade and the obligatory exchange of wind feed-in inside Germany. These flows were interrupted during the event. The tripping of several high-voltage lines, which started in northern Germany, split the UCTE grid into three separate areas (west, northeast and southeast) with significant power imbalances in each area. The power imbalance in the western area induced a severe frequency drop that caused an interruption of supply for more than 15 million European households (UCTE, 2007).

The country most affected was France, with 5 million customers, and Germany, where millions of customers were also affected, followed by Belgium, Netherlands, Italy and Spain, where hundreds of thousands of customers were left without electricity (European Commission, 2007). The incident appears to have been caused for three main reasons: firstly, E.ON Netz, the electricity transmission system operator at the origin of the power failure, had neither a security procedure in place or even the full technical tools to verify that the system was operating within the security limits. Secondly, other European transmission system operators did not receive information on the actions taken by the German transmission operator. Thirdly, the lack of sufficient investment, both at the level of the reliability and the operation of the grid, have been blamed. Other outstanding issues were the behaviour of distribution networks and in case of disturbances, the disconnection and reconnection of loads and generators (European Commission, 2007).

\section{Schematic map of UCTE area, split into three areas}

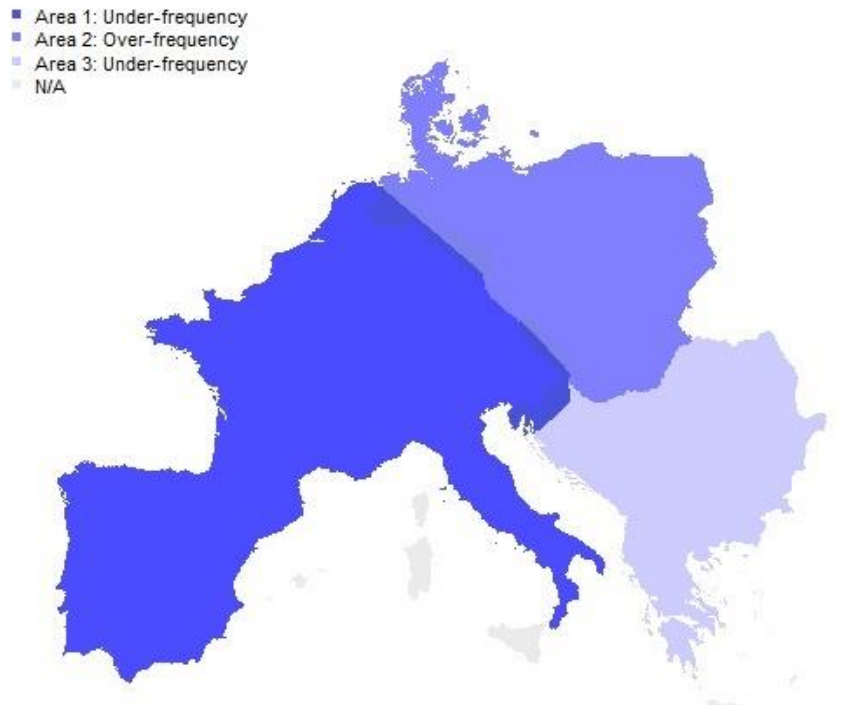

Source: Own illustration, based on data from UCTE (2007), "Final Report System Disturbance on 4 November 2006", UCTE, Brussels, available at: https://www.entsoe.eu/fileadmin/user upload/ library/publications/ce/otherreports/Final-Report20070130.pdf. 


\subsubsection{Energy's impact on resilient institutions in cities}

Energy governance, that is to say how stakeholders manage energy, has an impact on resilience in cities. Energy governance is affected by various factors including the type of energy sources and relevant technologies. From the late $19^{\text {th }}$ century, the electricity systems in some countries experienced a shift from small scale, unconnected networks towards centralised and vertically integrated systems (Lehtonen and Nyeb, 2009). This change occurred in response to the lack of connectivity of remote areas and the need of a more efficient and more dynamic energy supply to meet growing cities' needs. Large generation plants were built and connected to new national grids (Ruttera and Keirsteadb, 2012). From a governance perspective, the energy sector was dominated by monopolies, with a few large electricity or gas companies basically owning both the generation and the transmission and distribution utilities that were integrated together (Pollitt, 2012). Energy supply systems across the OECD countries mainly rely on large scale and national infrastructure notably because they operate at high loads (Kosmadakis, 2013), enable lower costs of production, and free urban centres from various externalities induced by the operating of energy supply systems (Ruttera and Keirsteadb, 2012).

The need for a more efficient energy supply system to reduce prices and increase the quality of service has led to the unbundling of the power system and to liberalization of the energy markets (Hatziargyriou et al, 2011). The liberalisation of energy sector has changed former energy governance arrangements (Figure 20), splitting up the integrated utilities into separate network business and other, empowering customers, enhancing private and competitive operations and investments as well as increasing transparency (IEA, 2013). In 2009, the European Union adopted the "Third Package" (European Commission, n.d.) to further deregulate the European energy market and to promote, among other things, the unbundling of energy suppliers from network operators, by establishing either Ownership unbundling, Independent System Operators (ISO) or Independent Transmission System Operators (ITSO). Ownership unbundling implies that all integrated energy companies sell off their gas and electricity networks. ISO are energy supply companies that still own transmission networks but appoint an independent firm to operate and do the maintenance of the transmission grid. ITSO are energy companies that have affiliates firms to operate the electric or gas grid they own (European Commission, n.d.). The emergence of numerous new energy companies -from multinationals to family scale generation firms - changed the vertically integrated model towards more competition and business decisions -such as the number or the type of plant built- based on the situation of the market (Energy UK, n.d.).

Figure 20. Choices of the structure for operations and planning of energy networks "Vertically integrated company"

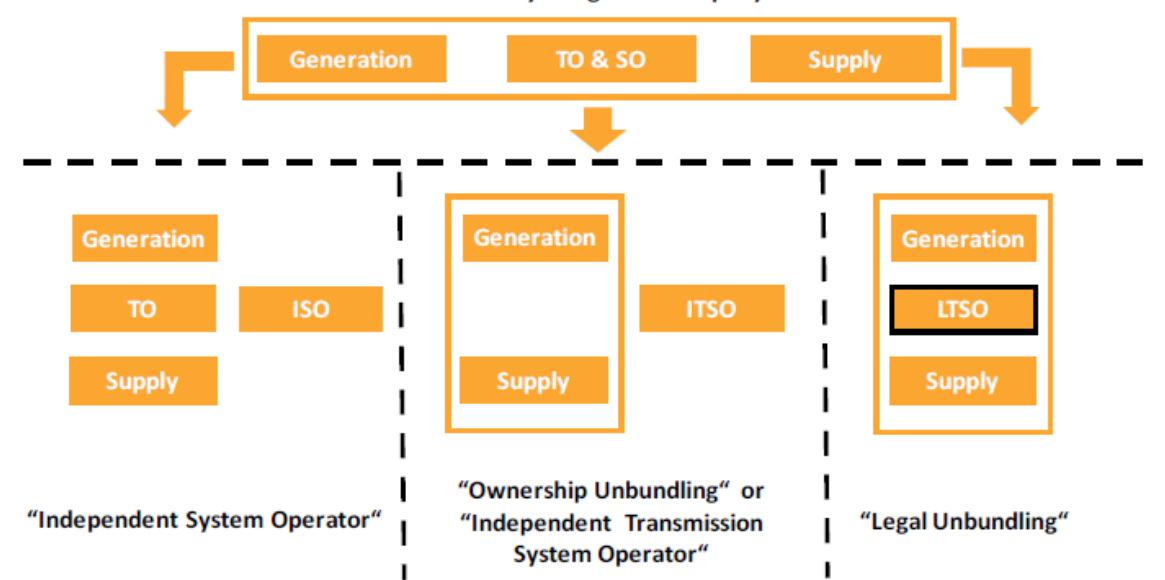

Source: IEA (2013), "Electricity Networks: Infrastructure and Operations", IEA, Paris, available at: https://www.iea.org/publications/insights/insightpublications/ElectricityNetworks2013 FINAL.pdf. 
Cities are now not only consuming but generating and distributing energy, thanks to the development of renewable energy technologies and infrastructure. Distributed energy systems (DES) refer to small-scale generation plants and local grids that are not centrally managed and are located close to final consumers to provide them with locally produced, distributed and stored electricity or heat (US Department of Energy, n.d.). They can be community and individual systems with the aim of meeting specific local energy needs (Kelly and Pollitt, 2011). Micro grids are key elements of DES: they are small parts of national or regional electricity distribution networks and are designed to provide power to small areas or buildings. They have the ability to be autonomous from the main grid - it is called the islanding mode (Su and Wang, 2012). Micro grids can be therefore used as a backup power source in case of blackout in the large-scale network, which ensures more reliability and security for the supply of energy (Schock and Sims, 2012).

The concept of energy autonomy is gaining importance across OECD regions and cities and refers to independent energy supply systems that do not rely on imported energy (Rae and Bradley, 2012), whose aim is to reach self-sufficiency and even more: the energy produced in excess can be either export or stored. It also implies self-governance and the participation of a large range of stakeholders at the local level, from individuals to local authorities and businesses. Although some drawbacks exist including the need for these local systems to be run at low capacity factors, they provide advantages including enhanced sustainability, lower costs of energy and lower carbon emission, as well as employment opportunities for local residents (Rae and Bradley, 2012).

Initiatives for decentralization of energy system including energy autonomy and more generally for local energy management emerge across OECD regions and cities. In Switzerland, the programme by the Federal Office for Energy (OFEN) promotes the development of Régions-Energie (EnergyRegions) (Suisse Energie, 2015) to create synergies between cities to exploit their available local renewable energy sources. The goal is for regions to become autonomous and self-sufficient but not to establish autarky: the aim is to exchange locally generated energy with neighbouring cities so that the region reaches equilibrium, reduces costs and generates benefits by exporting surplus energy. RégionsEnergie can undertake various projects including the creation of district heating networks. Austria is developing the same kind of programme. Ninety-nine regions labelled "Klima- und EnergieModellregionen" (Climate and Energy Model Regions) (Klima- und Energie- Modellregionen, n.d.) already exist through the country, which aims to reach energy self-sufficiency. Local authorities collaborate with private sector experts in the energy sector to free from their dependence on imported fossil fuels. For instance, the cities of the Leiblachtal region aim to create regional energy policy structures; and the Landeck region aims to cover its population's energy demand in electricity and heat with $100 \%$ renewable energies generated at the regional scale by designing a new urban energy system model that includes citizens as active stakeholders. Promotion of local energy supply systems is also active in Germany. The 100ee-Regionen programme (100\% Renewable Energy Regions) (Institut dezentrale Energietechnologien, 2014) helps more than 130 areas across the country to become selfsufficient by only using their local renewable energy resources. The programme has been exported at the EU level, creates partnerships between cities and promotes the adoption of joint Sustainable Energy Action Plans between different regions. 


\subsection{Conclusion}

This chapter discusses the questions; how does energy influence resilience in cities? What are the problems of resilience in cities that are influenced by energy use and production? It provides an overview of the relationship between urbanisation and energy, and of energy's impact on resilience in cities. Cities now mainly depend on fossil fuels, with their many negative spillover effects. As energy demand in cities is projected to grow, its impact is expected to be greater in future. Energy affects cities' economic resilience, given that energy prices influence urban industries as well as citizens' daily life. Energy also influences the urban environment. Cities are the cause as well as the victims of environmental issues related to energy, including emissions of GHG, heat and air pollutants. The social aspects of resilience in cities and disruption of energy supplies affect vast numbers of people over wide geographical areas and can cause regional and global effects through supply chains. Institutional resilience in cities is affected by various factors including the type of energy sources and relevant technologies.

Two approaches are proposed to address those issues. First is enhancing the cities' energy management to improve energy efficiency and to reduce energy consumption. Second is decreasing the dependence on fossil fuel by deploying renewable energy in cities. Managing energy smartly in cities can help cities absorb shocks, bounce back and adapt to the impact of chronic economic, environmental and social pressures. For example, power generation sector is the largest cause of $\mathrm{CO}_{2}$ emissions (IEA, 2015d) therefore saving energy in each sector including building and transport can be effective not only for reducing emissions from those sectors but also for reducing emissions from the power generation sector. Next chapter analyses the policy practices on energy in cities and explores how cities can be more resilient by policies to change energy use and production. 


\section{POLICY PRACTICES ON ENERGY IN CITIES}

Cities' energy policy has a major impact on urban resilience, as discussed in Chapter 1 . The role of energy in cities' resilience is likely to grow, given that urban energy demand is expected to increase (Figure 2). Cities are therefore required to respond to their needs through adequate urban policy. Nevertheless, the roles of cities in energy issues seem to be limited conventionally. National, and in some cases supra-national, authorities design objectives and policy interventions in the energy sector that frame the conditions for local action (OECD, 2012d). Local authorities have been playing a minor role, and the visibility of local government actions is limited under the United Nations Framework Convention on Climate Change (UNFCCC) and the Kyoto Protocol processes (OECD, 2008). However, the role of cities is changing, as illustrated by the COP21 negotiation process. One of the main achievements is the recognition of the critical role of cities and other non-state actors in building resilience at the international level, and in creating a low-carbon and sustainable world (UNFCCC, 2015a).

Pioneering cities have become more active on energy issues in recent years. These cities estimate data on energy use, set targets relevant to energy demand and supply, and conduct leading projects on energy efficiency. Several cities in the OECD have been encouraging the private sector to generate renewable energy within cities, including solar energy and waste heat. These actions are supported by an increasing recognition of cities' capacity to address disruptions in energy supplies caused by various shocks, and a growing awareness of energy security at the city level (ICLEI, 2014). This has become particularly noticeable in the wake of the Great East Japan Earthquake, which devastated eastern Japan (City of Kyoto, 2013b) and after Hurricane Sandy in the United States. Cities have the potential to address the challenges of resilience in cities related to energy because they can formulate and implement comprehensive urban policies, formulating place-based and locally tailored solutions. Local governments can significantly influence citizens' energy choices (IEA, 2009), offering a valuable lever for policies designed to increase resilience. Local governments are themselves one of the largest energy consumers in cities, and are in a position to organise their procurement to enhance resilience. This chapter analyses the practices cities can adopt to respond to issues on resilience in cities related to energy.

\subsection{Visions and targets}

\subsubsection{Cities' commitment to energy issues}

\section{Challenges to resilience posed by energy in cities}

Certain cities design urban policies for enhancing resilience by addressing the influence of energy issues on the economy, the environment, society and institutions. They develop visions with farreaching goals, including improving energy efficiency, increasing renewable energy deployment and achieving total energy self-sufficiency through locally produced renewable energy. Some cities aim to produce enough renewable energy locally to cover all the city's energy needs, and to champion sustainability by promoting reduction of energy consumption, better use of energy resources and more reliable energy distribution. Such visions are realised by setting the relevant targets for energy conservation and renewable energy deployment in cities, and also by outlining other dimensions of policy impacts, including reduction of GHG emissions and energy cost savings. Some cities have an active commitment to urban energy policies, and set ambitious targets that exceed targets set at the 
national level. Cities' motivation in formulating long-term visions and urban energy goals is to resolve environmental, social and economic issues relevant to aspects of urban resilience, including climate change, air pollution, fuel poverty and preparation for disruptions in the energy supply.

- Toronto is the largest city in Canada and the fourth-largest in North America. Its population is growing rapidly - it stood at more than 2.8 million people in 2014 and grew $4.5 \%$ between 2006 and 2011 (City of Toronto, 2012; City of Toronto, 2015a). The city is the second-largest centre for financial services in North America and has a diversified economic structure, with 12 key economic sectors (e.g. food and beverages, green technologies). Toronto's institutions of higher education include five universities and four colleges that in 2012, had a total of 73500 students. Local authorities, however, particularly need to address job creation while maintaining the attractiveness of the city to investors. New investments in the infrastructure network are needed, for example (City of Toronto, 2002 revised 2015; City of Toronto, 2016).

Barcelona is a large and growing city, whose population grew by $1.5 \%$ between 2004 and 2014 to more than 1.6 million. Its area is approximately 10000 hectares. The city's economic activity is supported by the service sectors, notably tourism, which accounted for more than $81.9 \%$ of the total value added in the City of Barcelona in 2010. The industrial sector accounted for $10.6 \%$ and the construction sector for 7.5\%. Barcelona's economic situation is at present uncertain (Barcelona City Council, n.d.c). The 2008 economic crisis hit the city hard, with critical negative consequences for the local labour market. Local unemployment reached $16.4 \%$ in 2014. The local authorities have mounted three major responses to these challenges: boosting the economy sustainably, improving social welfare and promoting urban regeneration, notably through the implementation of active policies in the field of energy management (Barcelona City Council, n.d.d; Barcelona City Council, n.d.e).

- Munich is the third-largest city in Germany, with a population of approximately 1.5 million inhabitants (2015), and grew by $17.1 \%$ between 2004 and 2014. It accounts for $17.6 \%$ of Bavaria's total GDP and hosts 94800 companies, primarily in the information and communication sectors. In 2012, the industrial sector accounted for $23.3 \%$ of the city's total value added; public and health services for $20.1 \%$ and the commercial, transport and financial services for $56.5 \%$ (City of Munich, n.d.b). Munich is exposed to growth-related issues, including rising expenditure in housing and mobility, aggravated by this population growth. The population is projected to grow by $15 \%$ from 2013 to 2030 . The city lacks land for housing, which is likely to increase social polarisation and poverty. The need to address climate change will become more urgent with population growth, as the city's reduction targets for polluting emissions have not all been realised (City of Munich, 2015b).

Kyoto had approximately 1.47 million inhabitants and approximately 690000 households in 2012. The city's area is about 83000 hectares, three quarters of which is covered by forest. Services, real estate, wholesale and retail, and manufacturing dominate the city's production, accounting for more than $70 \%$ of its economic activity. Although its large industrial areas are not located in the city, the city has a wide range of industries, including traditional industries, as well as advanced industrial technology including electronic components and measurement instrument. The city is an intellectual center, with 37 universities and colleges and around 14 million students, accounting for $10 \%$ of the city's population. A number of national and private institutes are also located in the city (City of Kyoto, 2013a). The city is confronted with rising challenges due to its increasing integration in the globalised world, which has made it more vulnerable to global shocks and pressures, including global warming and fluctuations in the energy supply. The city's population is ageing and declining, which is likely to entail a drop in tax income and an increase in social expenditures (City of Kyoto, 2011). 
- Bristol had approximately 0.4 million inhabitants in 2014 and has been undergoing significant demographic change, with a population growth of $11.8 \%$ between 2004 and 2014. Its total housing stock amounted to 193000 units in 2014 and is expected to increase by 15700 new units by 2026 (Bristol City Council, 2015b). Bristol is the European Green Capital of 2015 and benefits from a wide industrial base, with companies in high-tech, finance, retail and business services. However, it faces a variety of challenges, including persistent inequality among the city's districts; congestion and air pollution due to the shortages of investment in the transport sector; and a high cost of living, including housing prices onerous for younger residents (Bristol City Council, 2013a; Ferguson, n.d.).

- Perpignan's surface area is $68 \mathrm{~km}^{2}$, with a population of 0.1 million and a high population density of 1770 persons per $\mathrm{km}^{2}$. The industrial structure of the city is dominated by the commercial, transport and service sectors, which represent $70.4 \%$ of local firms (2013). Public bodies and the health sector account for $14.5 \%$ of local firms; the construction sector accounts for $9.8 \%$ of local companies; the industrial sector $4.3 \%$; and the agricultural activities $1 \%$. Perpignan's population grew at a mean annual rate of $0.8 \%$ from 2007 to 2012. Perpignan is the third-poorest of the 100 largest cities in France. Poverty and unemployment rates are on the rise, and the median income level has been decreasing, triggering health and housing problems, as well as a loss of social attractiveness of the urban centre. Active policies in the field of energy management (energy production, as well as support for upgrading housing) are important in improving housing conditions and promoting local employment (Perpignan City Council, 2014).

As an example of cities' visions of increasing energy self-sufficiency by renewable energy, the city of Perpignan, together with the Perpignan Méditerranée Commauté Urbaine, ${ }^{2}$ adopted a strategic vision in 2008 with the goal of becoming a "positive energy territory" by 2015 (Ministry of Ecology, Sustainable Development and Energy, France, n.d.) which produces renewable energy locally that exceeds the conurbation area's residential energy demands (Perpignan Méditerranée, 2015). Achieving self-sufficiency for the territory by generating clean energy was seen as a way to improve its ability to cope with current challenges and to build more sustainable and resilient economic, social and environmental models (Perpignan Méditerranée, 2012). Self-sufficiency has the potential to lessen economic risk and increase robustness if it is suitable to the conditions of the cities, by limiting the dependency of the territory on energy imports and fluctuations in energy prices, and by increasing local employment and economic activity. One of the chief motives for the initiatives is that the area is rich in renewable resources, enjoying 300 days of sunshine and 200 days of adequate wind per year. The area also holds assets in research and development, including the PROMES (Procédés, Matériaux et Energie Solaire) Laboratory, the DERBI competitive cluster, the Polytech'EnR, TECSOL and Solaire France (Ligue ENR, 2013). Population in Perpignan Méditerranée increased by $1.2 \%$ per year from 2005 to 2011, entailing a rise in energy consumption. Perpignan Méditerranée is in the Languedoc-Roussillon region, which is highly vulnerable to the impact of climate change, and at risk of dwindling water resources, coastal erosion, wildfires and difficulties in agriculture, an essential part of its economy. Both the city of Perpignan and the Communauté Urbaine suffer from rising levels of unemployment, which rose from 12.9\% in 2007 to 15\% in 2012 (INSEE, n.d.c) for the city of Perpignan and from $15.5 \%$ in 2007 to $18 \%$ in 2012 (INSEE, n.d.d) for the Communauté Urbaine. The Regional Climate Air Energy Scheme forecasts that 30\% to $40 \%$ of households in LanguedocRoussillon could fall into fuel poverty by 2020 should there be a rise in energy prices. This could be

\footnotetext{
${ }^{2}$ Perpignan Méditerranée Communauté Urbaine is an administrative body consisting of 36 cities in the vicinity of Perpignan, including the city itself. These cities have joined forces to increase their ability to develop large collaborative projects, including the project of becoming a "positive urban territory".
} 
more serious in the city of Perpignan, since $32 \%$ of households were already below the poverty line in 2011. A rise in the price of a barrel of oil to USD 200 would cost Perpignan Méditerranée EUR 300 million, due to household energy consumption (Perpignan Méditerranée, 2012).

Munich, a city with a much larger population and energy consumption, has developed a similar vision regarding the greening of energy supplied to the city, but includes a wider area for renewable energy production. In 2008, the city, with its 1.4 million inhabitants, launched its vision "Renewable Energies Expansion Campaign" through its municipality-owned utility company Stadtwerke München, with the goal of reaching $100 \%$ in renewable energy supply for the whole city by 2025 (C40 Cities, 2014) and of becoming the world's first city of more than one million inhabitants to achieve this goal (SWM, 2015a). A large percentage of the plants constructed for this purpose is located in Munich, although the company also uses plants located across Germany and Europe (Figure 21). In the region of Munich, the energy mix comprises 13 hydropower plants, a wind power plant, a geothermal power plant, a biomass power plant and 23 PV solar plants. Being connected to the European electricity grid and diversifying the energy mix in both the location of the plants and the types of renewable sources can help ensure continuity in its energy supply and compensate for the intermittent nature of the production of renewables. The city also plans to provide district heating exclusively from renewable energy sources by 2040 and to expand the programme to the western part of the city (SWM, 2015b). The city's goal in promoting active energy policies is to mitigate climate change and improve air quality (SWM, n.d.) by cutting GHG emissions, while meeting the energy demands of a growing urban population (City of Munich, 2015c).

Figure 21. Renewable energy plants of SWM in Munich, Germany and Europe

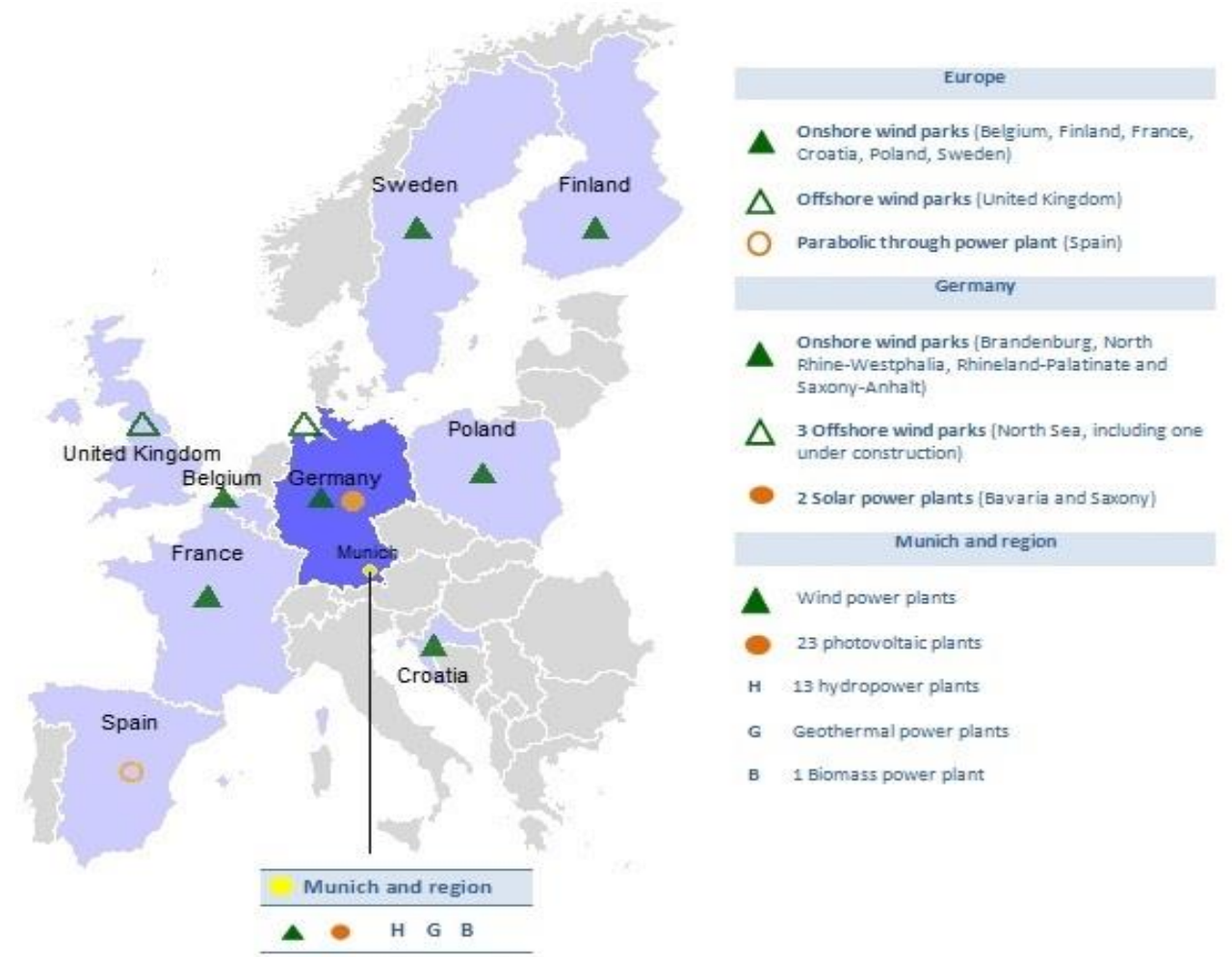

Source: Own illustration, based on data from SWM (2016a), "SWM's Green Energy Plants - Munich and Region, Germany and Europe", available at: https://www.swm.de/dam/jcr:6b51fbab-df16-493b-92e4-5c4385e50dfd/map-renewable-energies.pdf.

Through these renewable energy targets, the city also seeks to reduce its dependency on nonrenewable energy imports that leave it vulnerable to energy price fluctuations (City of Munich, 2014b) 
and fuel poverty. This aims to capitalise on local resources, since Munich is one of the sunniest cities in Germany, with 1700 hours of sunshine a year (City of Munich, n.d.c), making it a good candidate for developing solar energy. Munich is also able to exploit geothermal energy production, as it is located in the Bavarian Molasse Basin, which has ample reserves of hot water (SWM, 2015b).

The vision of promoting an independent and decentralised energy supply system is developed by Kyoto. The city is well-known as the place where the Kyoto Protocol was adopted, at the Third Conference of the Parties to the United Nations Framework Convention on Climate Change (COP3) in 1997. Kyoto enacted the Global Warming Countermeasures Ordinance in December 2004 for the first time, for Japanese local governments, and set targets to reduce the amount of GHG in the city by $40 \%$ before 2030 and 25\% before 2025 (City of Kyoto, 2013c). The Global Warming Countermeasures plan has set a road map for achieving these targets. The city also settled on a Strategy for the Promotion of Kyoto City's Energy Policy in December 2013. Its level of access to large-scale centralised energy supply systems had decreased, due to pressures on energy supplies after the Great East Japan Earthquake of 2011. For instance, the capacity of the Tokyo electric power company fell approximately 40\%, from 52 million kilowatts to 31 million kilowatts (METI, 2011). This effect was also felt, for example, in the service area of the Kansai electric power company where Kyoto locates. In the summer of 2011 and in the winter of 2012, citizens were required to cut electricity consumption by $10 \%$ given the long-term energy shortages (METI, 2013). The development of an independent and decentralised energy supply system was therefore of utmost importance for citizens. In addition, the earthquake and ensuing nuclear disaster highlighted the need to create an energy system that could cope with natural disasters and to build a society capable of sustaining economic growth without increased energy consumption (City of Kyoto, 2013a).

Kyoto's strategy demonstrates the direction of the city's energy policies, and clarifies how energy policies can contribute towards the vision set forth in the city's master plan, "Flying into the future! Miyako Plan". This strategy is also reflected in the implementation of Kyoto's global warming countermeasures plan, as well as in other programmes and policies. As part of the energy strategy, the city has established quantitative targets necessitating a more than $15 \%$ reduction in energy consumption from 2010 to 2020, along with a more than threefold increase in the proportion of energy generated from renewable sources (Figure 22) (City of Kyoto, 2013a). 
Figure 22. Targets of urban energy policy in Kyoto

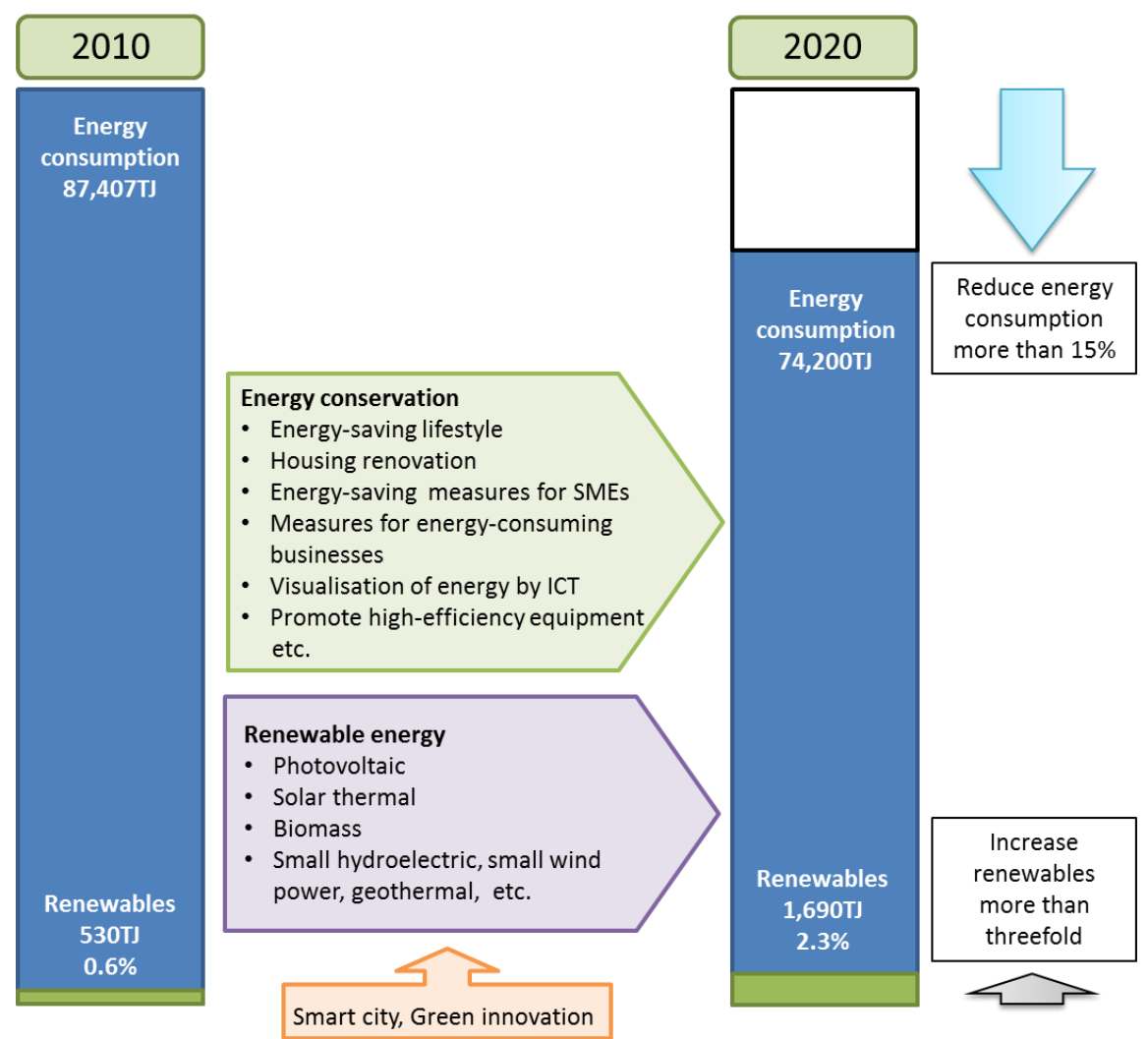

Source: City of Kyoto (2013a), "Kyoto city strategy for promoting energy policy", City of Kyoto, Kyoto, available at: http://www.city.kyoto.lg.jp/kankyo/cmsfiles/contents/0000161/161721/senryaku honbun.pdf.

Toronto has concentrated its efforts and policy actions on both improving the sustainability of its environmental, economic and social models, and the resilience of its population to climate change (City of Toronto, n.d.b). With the "Climate Change, Sustainable Energy and Clean Air Action Plan" issued in 2007 and the "Power to Live Green" framework released in 2009, the city envisaged becoming the champion city of sustainability through energy management. The city has pledged to become the most sustainable city in North America (City of Toronto, n.d.c). The city set its targets on GHG emissions, energy consumption and renewable energy production (Table 7) (City of Toronto, 2009; City of Toronto, 2015c). Its reasons for setting these targets are manifold. The city had been suffering from disruptions of its energy supply due to events including the December 2013 ice storm and the Northeast blackout of 2003. The city also intends to decrease adverse health effects, since the number of smog and pollution-related fatalities had risen to a total of 1700 people annually (City of Toronto, 2009). Rapid urban growth will increase electricity needs from $5000 \mathrm{MW}$ in 2009 to $6100 \mathrm{MW}$ in 2050 (City of Toronto, 2009). Toronto needs to reduce its dependency on non-renewable energy sources. Through the development of green energy and smart energy management, financial losses should be reduced to curb its energy bill of an average CAD $\$ 4.5$ billion per year (City of Toronto, 2009). The city's vision is also designed to decrease fuel poverty, which is of particular significance in the city's severe winter climate. These actions have been undertaken in the context of Ontario's decision to phase out coal power plants. In 2014, the province completely eliminated coal sources from its energy mix, promoting the use of new energy sources in cities, including nuclear, hydro and other renewable sources (Ministry of Energy, Ontario, 2015). 
Table 7. Targets of urban energy policy in Toronto

\begin{tabular}{|l|l|l|l|}
\hline SOURCE & By 2012 & By 2020 & By 2050 \\
\hline $\begin{array}{l}\text { Conservation } \\
\text { Electricity* }\end{array}$ & $\begin{array}{l}\text { Reduce by } 200 \mathrm{MW} \\
\text { (2007 baseline) }\end{array}$ & $\begin{array}{l}\text { Reduce by } 550 \mathrm{MW} \\
\text { (2007 baseline) }\end{array}$ & $\begin{array}{l}\text { Reduce by } 1050 \mathrm{MW} \\
\text { (2007 baseline) }\end{array}$ \\
\hline $\begin{array}{l}\text { Conservation } \\
\text { Natural gas heat }\end{array}$ & $\begin{array}{l}\text { Reduce by } 240 \mathrm{Mm}^{3} \\
\text { (2007 baseline) }\end{array}$ & $\begin{array}{l}\text { Reduce by } 730 \mathrm{Mm}^{3} \\
\text { (2007 baseline) }\end{array}$ & $\begin{array}{l}\text { Reduce by } 1560 \mathrm{Mm}^{3} \\
\text { (2007 baseline) }\end{array}$ \\
\hline $\begin{array}{l}\text { Renewable electricity } \\
\text { generation }\end{array}$ & $\begin{array}{l}\text { Increase by } 120 \mathrm{MW} \\
\text { (2007 baseline) }\end{array}$ & $\begin{array}{l}\text { Increase by } 550 \mathrm{MW} \\
\text { (2007 baseline) }\end{array}$ & $\begin{array}{l}\text { Increase by } 1000 \mathrm{MW} \\
\text { (2007 baseline) }\end{array}$ \\
\hline Renewable thermal energy & $\begin{array}{l}\text { Displace } 20 \mathrm{Mm}^{3} \text { of natural } \\
\text { gas (2007 baseline) }\end{array}$ & $\begin{array}{l}\text { Displace } 90 \mathrm{Mm}^{3} \text { of natural } \\
\text { gas (2007 baseline) }\end{array}$ & $\begin{array}{l}\text { Displace } 200 \quad \mathrm{Mm}^{3} \text { of } \\
\text { natural gas (2007 baseline) }\end{array}$ \\
\hline GHG emissions reduction & - & $\begin{array}{l}\text { Reduce by } 30 \% \\
\text { (1990 baseline) }\end{array}$ & $\begin{array}{l}\text { Reduce by } 80 \% \\
\text { (1990 baseline) }\end{array}$ \\
\hline
\end{tabular}

Note: * Conservation targets are in addition to the existing $330 \mathrm{MW}$ reduction by 2010 called for in the Toronto Directive from the Ontario Power Authority. Based on 2007 levels of 5000 megawatts (MW) of electricity consumption and 4200 million cubic metres (Mm3) of natural gas consumption.

Source: City of Toronto (2009), "The Power to Live Green - Toronto's Sustainable Energy Strategy" (October), available at: http://www1.toronto.ca/city of toronto/environment and energy/key priorities/files/pdf/2009-10 report.pdf; City of Toronto (2015c), "Toronto Environmental Progress Report 2015", Toronto, Canada, available at: http://www.toronto.ca/legdocs/mmis/2016/pe/bgrd/backgroundfile-90610.pdf.

Bristol is committed to becoming the first city in the UK in sustainable energy (Bristol 2015, 2015b). To achieve this goal, the city plans to reduce $\mathrm{CO}_{2}$ emissions by $40 \%$ by 2020 and $80 \%$ by 2050 (Bristol City Council, 2014) and to reduce city-wide energy consumption by $30 \%$ by 2020 (Bristol City Council, n.d.a), from a 2005 baseline. The city also plans to purchase $15 \%$ of its electricity from renewable sources by 2010 and $20 \%$ by 2020 (Bristol 2015, 2015a). The aim of the city in setting these targets is to mitigate climate change and its environmental costs, including increased flood risks and drier summers. Several economic advantages also motivate Bristol's energy policy. By reducing GHG emissions, the city expects to alleviate its carbon tax load, which could slow down the recovery process of the local economy in case of crisis. Indeed, as a large energy user, the council has to yield to the Carbon Reduction Commitment (CRC) and pay a charge to the central UK government for its emissions of $\mathrm{CO}_{2}$. With a charge of GBP 12 per $\mathrm{CO}_{2}$ tonne emitted, the total carbon tax load of the city reached GBP 750000 in 2013 (Bristol City Council, n.d.c). The city therefore also seeks to improve economic performance and job creation, especially in the clean energy industry, by limiting GHG emissions. The city also aims to reduce its dependency on imported fossil fuels, to avoid the significant economic consequences of a possible oil crunch in the future, and to ensure energy security to its citizens (Bristol Green Capital and the Bristol Partnership, 2007).

Various perspectives have been adopted regarding the relationship between energy, the environment, society and the economy. Barcelona has focused on four strategic objectives: improving energy efficiency and reducing energy consumption in the city, reducing GHG emissions and improving urban air quality (in particular NOx gases and $\mathrm{PM}_{10}$ particles), and improving the quality of energy supply (Barcelona City Council, n.d.a). The city has committed to combat climate change and to cut GHG emissions per capita by $40 \%$ from the rate that prevailed in 2005. In 2013, the city council's Department of Resources concluded a two-year contract with the energy provider of the city - Endesa Energia S.A.U, the top energy distributor in Catalonia - to ensure that each year, $100 \%$ of the electricity supplied to the council's buildings and facilities comes from renewable sources and/or high efficiency cogeneration. The parties have agreed to renew this clause both in the extension of the energy supply contract and for the future bids in the coming years (Barcelona City Council, n.d. $f$; Barcelona City Council, n.d.k). 


\subsubsection{How cities' energy policies relate to national and international policy frameworks}

Energy policy can bring national and local governments into conflict. For example, the construction of the Santa Llogaia-Baixas electrical network connecting Spain and France faced opposition from local communities on both sides of the border in the 1990s and in 2003 (IEA, 2015a). The deployment of wind turbines in Netherlands was also strongly opposed by the citizens and local authorities of the city of Frylân. Although the area owned significant assets to exploit the energy source, they feared that they would be forced to bear the costs without benefitting from the construction of large-scale renewable energy plants (OECD, n.d.a). On the contrary, active local efforts can raise network capacity issues if a city's deployment of distributed generation systems overloads the whole grid (Kane and Ault, 2014). However, ambitious local actions can also create dynamism in energy policy and become a source of inspiration for national and regional policies more generally. For instance, the EU Directive on the Energy Performance of Buildings finds its roots in some German local authorities' zero-energy building measures (European Association of Local Authorities in Energy Transition, 2013). Co-ordination among policies across levels of the governments is therefore crucial in energy management.

National governments have policy frameworks on resilience that outline the role of cities (Table 8). Some cities have more advanced visions and targets than other levels of government (Table 9). Energy policies in Europe are basically framed by EU decisions, which guide national frameworks. The " $3 \times 20$ " Energy package (2008) set three main targets for the EU as a whole, to be met in 2020: a $20 \%$ cut in GHG emissions from 1990 levels, $20 \%$ of EU energy from renewables and a $20 \%$ improvement in energy efficiency. It provides incentives for countries to meet and exceed their renewable energy production targets through the co-operative mechanism of statistical transfers that subsidises countries with elevated levels of production (European Commission, 2015a). The EU "Energy Efficiency Directive" (2012) sets legal binding measures for all stakeholders in European countries, including energy distributors, public sector and industry; and made it mandatory for member countries to design country-specific "National Energy Efficiency Action Plans" (NEEAP). The United Nations General Assembly declared 2012 the International Year of Sustainable Energy for All, acknowledging the importance and urgency of energy challenges. The Secretary-General's Sustainable Energy for All initiative seeks to identify and mobilise action by all stakeholders in support of energy access, energy efficiency and increasing the share of renewable energy (United Nations, 2011). The Paris Agreement of COP21 recognises the critical role of cities in the building of a low-carbon, resilient and sustainable future for countries (UNFCCC, 2015a). It emphasises the need for local governments to get involved in the programmes previously created at the COP20 in Lima, Peru: the Non-State Actor Zone for Climate Action (NAZCA) platform and the Lima Paris Action Agenda (LPAA). Commitments taken by national governments include increasing the number of cities and regional governments that implement binding climate action plans; developing international financing tools addressed to sub-national governments; and improving co-operation between cities at the international scale (UNFCCC, 2015b).

The targets of Perpignan and Perpignan Méditerranée are more ambitious than EU and national policies. France instituted the Grenelle de l'Environnement in 2007 to define national objectives and is also implementing a "National Renewable Energy Action Plan" (2010) in the context of the "3x20" EU package. It aims to reach $23 \%$ of renewable energy in total energy production by 2020 (IEA, 2015b). The recent "Energy Transition Act" (2015) complemented this plan by setting the overall target to reach the share of $32 \%$ of energy consumed from renewable energy sources by $2030,40 \%$ reduction of GHG emissions and 30\% decrease of energy consumption from fossil fuels. The framework also plans to halve the share of nuclear energy in energy consumption by 2025 . The Grenelle de l'Environnement made it mandatory for cities with more than 50000 inhabitants to develop a five-year "Territorial Climate and Energy Plan" (Perpignan City Council, 2012). In 2012, 
Perpignan Méditerranée has devised the "Climate and Energy Territorial Plan 2012-2017", which has six strategic objectives, including creating a positive energy area that aims to cover $100 \%$ of energy consumption with locally produced renewable energy for the conurbation (Perpignan Méditerranée, 2012).

Munich has also established an ambitious plan that goes beyond both EU policies and national legislation. The city aims to reach a $100 \%$ share of renewable electricity in the city's final energy consumption by 2025 . The federal government's targets are to increase the share of renewable energy in total energy consumption to $40 \%-45 \%$ by $2025,55-60 \%$ by 2035 and $80 \%$ by 2050 in the "Renewable Energy Sources Act," revised in 2014. This strategic framework aims to foster the development and the adoption of cost-effective renewable technologies. The "Energy Concept" published in 2010 plans to raise the share of renewables in final energy consumption by $60 \%$, to cut GHG emissions in Germany by $80 \%-95 \%$ by 2050 compared to 1990 baseline, and to reduce primary energy consumption by $50 \%$ compared to 2008 levels. 
Table 8. National policy frameworks on resilience in selected countries

\begin{tabular}{|c|c|c|c|c|}
\hline Country & Framework & $\begin{array}{l}\text { Year issued- } \\
\text { targeted year }\end{array}$ & Motivations / Outline / Objectives & $\begin{array}{l}\text { Role of cities and sub-national } \\
\text { governments (SNGs) }\end{array}$ \\
\hline France & $\begin{array}{l}\text { National Strategy of } \\
\text { Ecological } \\
\text { Transition Towards } \\
\text { Sustainable } \\
\text { Development }\end{array}$ & $2015-2020$ & $\begin{array}{l}\text { The plan seeks to develop a long-term } \\
\text { ecological transition strategy. It aims to } \\
\text { restructure the energy system to curb } \\
\text { energy poverty and promote economic } \\
\text { competitiveness. This will be achieved } \\
\text { by a more efficient use of resources } \\
\text { and deploying renewable energy. }\end{array}$ & $\begin{array}{l}\text { Local authorities are considered the } \\
\text { most relevant actors for implementing } \\
\text { solutions tailored to local environmental } \\
\text { and economic issues. Local projects } \\
\text { (e.g. Agenda 21) have been set up to } \\
\text { prepare for specific local challenges in } \\
\text { future. }\end{array}$ \\
\hline Germany & $\begin{array}{l}\text { Central Projects for } \\
\text { the Energy } \\
\text { Transition - 10- } \\
\text { points Energy } \\
\text { Agenda of the } \\
\text { Ministry of Economy } \\
\text { and Energy }\end{array}$ & $\begin{array}{l}\text { 2014-N/A } \\
\text { (depends on } \\
\text { the reform) }\end{array}$ & $\begin{array}{l}\text { This policy framework describes the } \\
\text { programmes set by the German } \\
\text { Federal Government to accomplish the } \\
\text { Energy Transition. Through building a } \\
\text { more resilient energy system based on } \\
\text { energy efficiency and renewable } \\
\text { energy, the aim is to achieve a } \\
\text { sustainable and prosperous future, } \\
\text { while keeping the German energy- } \\
\text { intensive industrial network competitive. }\end{array}$ & $\mathrm{N} / \mathrm{A}$ \\
\hline \multirow[t]{2}{*}{ Japan } & $\begin{array}{l}\text { Fundamental Plan } \\
\text { for National } \\
\text { Resilience - } \\
\text { Creating a Strong } \\
\text { and Resilient } \\
\text { Country }\end{array}$ & $\begin{array}{c}2014 \\
\text { Revised } \\
\text { every } 4 \text { years }\end{array}$ & $\begin{array}{l}\text { This plan was drawn up after the Great } \\
\text { East Japan Earthquake. It promotes } \\
\text { initiatives for building national resilience } \\
\text { by ensuring the continuity of energy } \\
\text { supply and of the social economy even } \\
\text { in case of disaster. }\end{array}$ & $\begin{array}{l}\text { This framework strengthens the role of } \\
\text { local authorities in building resilience } \\
\text { by designing Regional Plans and } \\
\text { proper assistance from the national } \\
\text { government, as well as government- } \\
\text { wide information sharing. }\end{array}$ \\
\hline & $\begin{array}{l}\text { Strategic Energy } \\
\text { Plan }\end{array}$ & $\begin{array}{c}\text { 2013-N/A } \\
\text { Latest } \\
\text { amendment } \\
2014\end{array}$ & $\begin{array}{l}\text { This strategic framework addresses } \\
\text { policy issues in the long term, and } \\
\text { comprehensive directions of energy } \\
\text { policy based on energy demand and } \\
\text { supply prospects for the next } 20 \text { years. }\end{array}$ & $\begin{array}{l}\text { This framework promotes renewable } \\
\text { energy development and decentralised } \\
\text { energy management. It strengthens } \\
\text { stability of energy supply of sub- } \\
\text { national governments' facilities in case } \\
\text { of energy disruptions. }\end{array}$ \\
\hline Spain & $\begin{array}{l}\text { Long-Term Strategy } \\
\text { for Energy } \\
\text { Renovation in the } \\
\text { Building Sector }\end{array}$ & $2014-2020$ & $\begin{array}{l}\text { Following an EU Directive, the } \\
\text { programme provides a framework for } \\
\text { making energy renovations in } \\
\text { residential and non-residential buildings } \\
\text { economically viable and a generator of } \\
\text { employment. }\end{array}$ & $\begin{array}{l}\text { Local programmes for energy efficiency } \\
\text { and building renovation are essential to } \\
\text { promote business opportunities. } \\
\text { However, compatibility issues between } \\
\text { programmes of municipal, regional and } \\
\text { state programmes have to be resolved. }\end{array}$ \\
\hline UK & $\begin{array}{l}\text { Climate Resilient } \\
\text { Infrastructure: } \\
\text { Preparing for a } \\
\text { Changing Climate }\end{array}$ & 2011-N/A & $\begin{array}{l}\text { This plan ensures resilience and the } \\
\text { adaptation of energy and other } \\
\text { infrastructure to extreme weather } \\
\text { events, climate change and } \\
\text { demographic change, in order to } \\
\text { maintain economic growth. }\end{array}$ & $\begin{array}{l}\text { This policy framework encourages local } \\
\text { authorities and the Local Enterprise } \\
\text { Partnerships to co-ordinate actions to } \\
\text { adapt infrastructure to climate change, } \\
\text { and to boost local resilience and } \\
\text { minimise economic risk. }\end{array}$ \\
\hline
\end{tabular}

Source: OECD (2015i), "National Policy Frameworks on Resilience and Cities", Paris, available at: http://www.oecd.org/gov/regional-policy/national-policy-resilience-frameworks.pdf ; Ministry of Ecology, Sustainable Development and Energy, France (2015), "Stratégie Nationale de Transition Ecologique vers un Développement Durable 20152020" ("National Strategy of Ecological Transition Towards Sustainable Development 2015-2020"), Ministry of Ecology, Sustainable Development and Energy, Paris, available at: www.developpement-durable.gouv.fr/IMG/pdf/SNTEDD.pdf; HM Government (2011), "Climate Resilient Infrastructure: Preparing for a Changing Climate", The Stationery Office Limited, UK, (May), available at: https://www.gov.uk/government/uploads/system/uploads/attachment data/file/69269/climate-resilientinfrastructure-full.pdf; Ministry of Development, Spain (2014), "Long-Term Strategy for Energy Renovation in the Building Sector in Spain Pursuant to Art.4 of Directive 2012/27/EU", (June), available at: http://www.fomento.gob.es/NR/rdonlyres/772D26EF6906-4AD9-9253-775615069E34/130070/ESArt4ENENER2014010090000ENTRA00.pdf; Cabinet Secretariat (2014), "Fundamental Plan for National Resilience, $\quad$ Cabinet Secretariat, Tokyo, http://www.cas.go.jp/jp/seisaku/kokudo kyoujinka/pdf/kk-honbun-h240603.pdf; Agency for Natural Resources and Energy (2014c), "Strategic Energy Plan", Agency for Natural Resources and Energy, Tokyo, www.enecho.meti.go.jp/category/others/basic plan/pdf/140411.pdf; Ministry of Economy and Energy, Germany (2014), "Central Projects for the Energy Transition - 10-points Energy Agenda of the Ministry of Economy and Energy" (brochure), available at: www.bmwi.de/BMWi/Redaktion/PDF/0-9/10-punkte-energie-agenda, property=pdf, bereich=bmwi2012,sprache=de, rwb=true.pdf. 
Table 9. Targets of urban energy policy in selected cities, national governments and EU

\begin{tabular}{|c|c|c|c|}
\hline & Renewable energy deployment & Energy conservation & Reduction of GHG emissions \\
\hline $\begin{array}{l}\text { Perpignan } \\
\text { and Perpignan } \\
\text { Méditerranée }\end{array}$ & $\begin{array}{l}100 \% \text { (2015) } \\
\text { (Share of locally produced RE in } \\
\text { residential electricity } \\
\text { consumption in Perpignan } \\
\text { Méditerranée) }\end{array}$ & $\mathrm{N} / \mathrm{A}$ & $6.4 \%(2010-2017)$ \\
\hline France & $\begin{array}{l}23 \%(2020), 32 \%(2030) \\
\text { (Nation as a whole) }\end{array}$ & $\begin{array}{l}30 \%(1990-2030) \\
\text { (Fossil fuels) }\end{array}$ & $40 \%(1990-2030)$ \\
\hline Munich & $100 \%(2025)$ & $\mathrm{N} / \mathrm{A}$ & N/A \\
\hline Germany & $\begin{array}{l}40-45 \%(2025), 55-60 \%(2035), \\
80 \%(2050)\end{array}$ & $50 \%(1990-2050)$ & $80-95 \%(1990-2050)$ \\
\hline Bristol & $\begin{array}{l}20 \%(2020) \\
\text { (Purchased) }\end{array}$ & $30 \%(2005-2020)$ & $\begin{array}{l}40 \%(2005-2020) \\
80 \%(2005-2050)\end{array}$ \\
\hline United Kingdom & $\begin{array}{l}15 \%(2020) \\
\text { (Purchased and/or locally } \\
\text { produced) }\end{array}$ & $\mathrm{N} / \mathrm{A}$ & $\begin{array}{l}\text { Limit } \mathrm{CO}_{2} \text { emissions to: } \\
3018 \mathrm{MtCO}_{2} \mathrm{e}(2008-2012) \\
2783 \mathrm{MtCO}_{2} \mathrm{e}(2013-2017) \\
2544 \mathrm{MtCO}_{2} \mathrm{e}(2018-2022) \\
1950 \mathrm{MtCO}_{2} \mathrm{e}(2023-2027)\end{array}$ \\
\hline Barcelona & $\begin{array}{l}\text { At least 15\% (council's electricity) } \\
100 \% \text { (council's electricity } \\
\text { provided by Endesa Energia SAU) } \\
\text { (2015) }\end{array}$ & $\mathrm{N} / \mathrm{A}$ & $\begin{array}{l}20 \%(2008-2020) \\
40 \%(2030)\end{array}$ \\
\hline Spain & $\begin{array}{l}22.7 \% \text { for all energy (2020) } \\
\text { (share of renewables generated } \\
\text { in the consumption of electricity: } \\
40 \% \text {, Heating/cooling: } 18.9 \% \text {, } \\
\text { Transport: } 13.6 \% \text { ) }\end{array}$ & $\mathrm{N} / \mathrm{A}$ & $15 \%(1990-2012)$ \\
\hline European Union & $\begin{array}{l}20 \%(2020) \\
27 \%(2030)\end{array}$ & $\begin{array}{l}20 \%(2020) \\
27 \%(2030)\end{array}$ & $\begin{array}{l}20 \%(2020) \\
40 \%(1990-2030) \\
80-95 \%(1990-2050)\end{array}$ \\
\hline
\end{tabular}

Source: Ministry of Ecology, Sustainable Development and Energy, France (n.d.), "La transition énergétique pour la croissance verte" ["Energy transition for green growth"] (brochure), available at : http://www.developpementdurable.gouv.fr/IMG/pdf/LANGUEDOC ROUSSILLON Perpignan.pdf; IEA (2015b), IEA/IRENA Joint Policies and Measures Database, http://www.iea.org/policiesandmeasures/renewableenergy/ (accessed September 2015).; C40 Cities (2014), http://cityclimateleadershipawards.com/mayors-voices-munich-mayor-hep-monatzeder/ (accessed September 2015); Bristol 2015 (2015a), "How to promote renewable energy generation", The Bristol Method, Bristol 2015, Bristol, (May), available at: https://www.bristol2015.co.uk/media/filer public/d6/b7/d6b70312-0c1d-45f0-ba20-

354c6eac4636/how to promote renewable energy generation.pdf; Bristol City Council (n.d.a), "Council Action on Climate Change", http://www.bristol.gov.uk/page/environment/council-action-climate-change\#jump-link-0 (accessed Sept 2015); Bristol City Council (2014), "Environmental Statement", http://ec.europa.eu/environment/emas/pdf/videoPage/ES Bristol City Council.pdf; Barcelona City Council (n.d.f), "Pla d'eficiència energètica en edificis municipals" " (brochure), available at: http://governobert.bcn.cat/sites/default/files/docs/presentacio eficiencia energetica.pdf; Barcelona City Council and Barcelona Energy Agency (2013), "Barcelona Energy Self-Sufficiency Plan" (brochure), (April), available at: http://www.energycities.eu/IMG/pdf/Barcelona-Energy-Agency Irma-Soldevilla.pdf; Barcelona City Council (2012), "Mesura de Govern: Programa d'llles Autosuficients de Barcelona" [Government's measure: Programme of self-sufficiency for the city blocks in Barcelona], available at: http://governobert.bcn.cat/sites/default/files/MG H\%C3\%A0bitat Illes 190112.pdf; European Commission (2016a), "2020 Energy Strategy", http://ec.europa.eu/energy/en/topics/energy-strategy/2020-energy-strategy (accessed January 2016); European Commission (2016b), "2030 Energy Strategy", http://ec.europa.eu/energy/en/topics/energy-strategy/2030-energystrategy (accessed January 2016); European Commission (2016c), "2050 Energy Strategy", http://ec.europa.eu/energy/en/topics/energy-strategy/2050-energy-strategy (accessed January 2016). 


\subsection{Urban development}

\subsubsection{Improving energy efficiency in housing, buildings and districts}

Enhancing energy efficiency in housing and buildings

The housing and building sector has a large role to play in creating a built environment that can support managing energy smartly in cities. Energy consumption in the sector has been increasing continuously and occupies a certain share (Figure 23, Figure 24). Improvement in energy efficiency of housing and buildings is thus a fundamental way of achieving policy objectives.

Figure 23. Final energy consumption by sector in OECD countries (Mtoe)

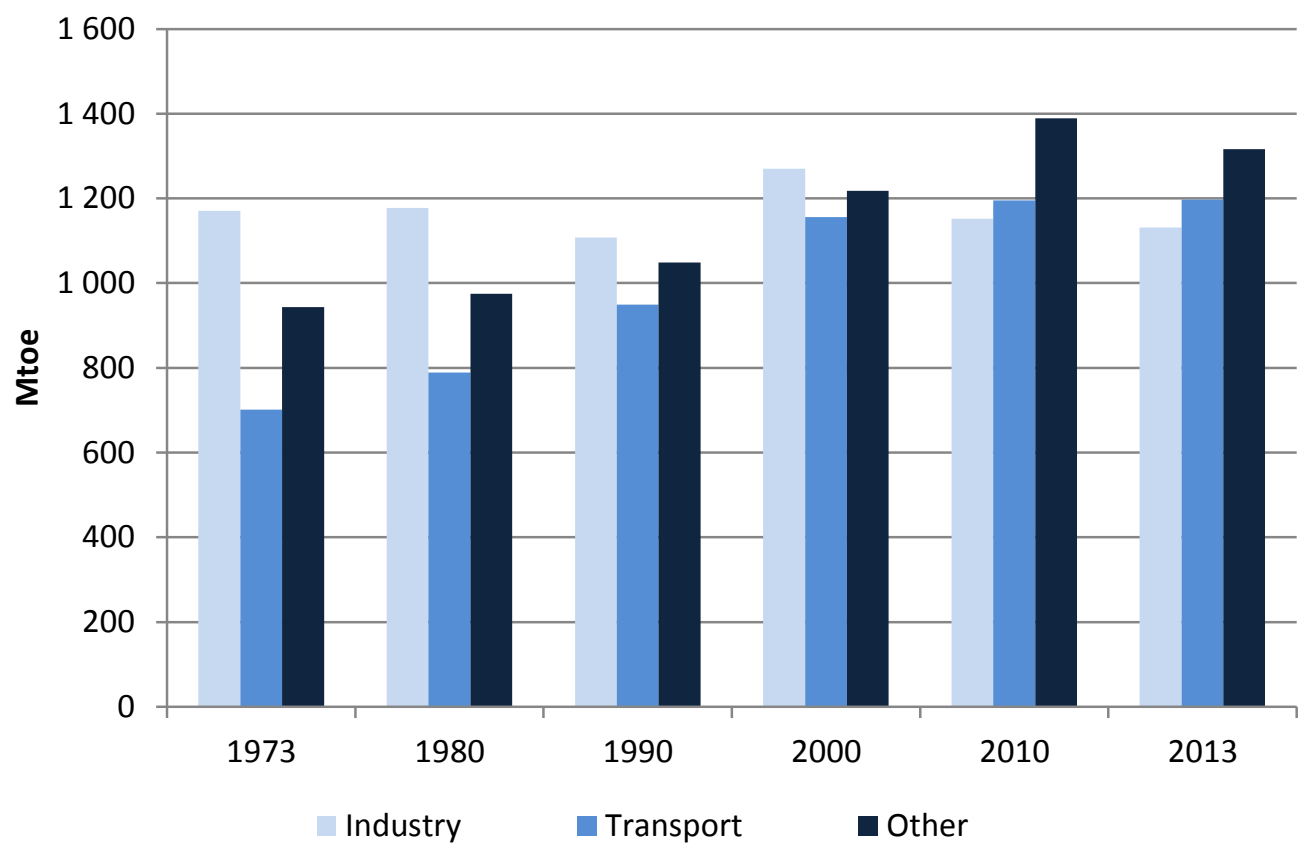

Note: "Other" includes residential, commercial and public services, agriculture/forestry, fishing and non-specified.

Source: Based on data from OECD (2015c), "Energy Balances of OECD Countries 2015", OECD Publishing, Paris, http://dx.doi.org/10.1787/energy bal oecd-2015-en. 
Figure 24. Breakdown of final energy consumption in other sector in Figure 23 (2013)

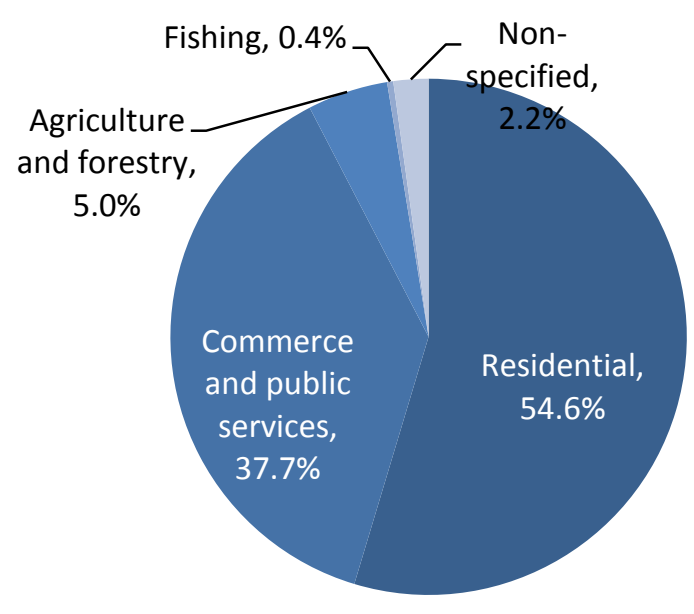

Source: Based on data from OECD (2015e), “OECD.Stat”, OECD, Paris, http://stats.oecd.org/ , (accessed 3 December 2015).

Instruments cities use to enhance energy efficiency of housing and buildings include economic policy tools, technical assistance and regulatory policy tools. Economic policy tools for improving energy efficiency of housing and buildings are provided by both national and sub-national governments. For example, Toronto provides various financial support programmes for local residents and community groups to improve their energy efficiency. The "Home Energy Loan Program" (HELP) supports individuals who cannot afford the renovation costs of retrofitting their houses. The programme offers loans at low interest rates with 15 repayment periods, which are attached to the property (City of Toronto, n.d.d). Bristol started a four-year retrofitting programme, "WarmUp Bristol", in 2014, which aims to improve energy efficiency in privately owned houses, with the goal of reducing fuel poverty. This programme targets 30000 houses and is one of the most ambitious energy efficiency schemes in the UK. Bristol City Council received GBP 7.2 million from the UK's Department of Energy and Climate Change (DECC) for this programme, as well as from different sources including the European Union (Bristol 2015, 2015c). Kyoto provides financial assistance for improving the energy efficiency of housing in addition to the national government's subsidies. The national government offers financial assistance for insulating the windows, outer walls, roof, ceiling and floors of existing houses, and the city government covers the insulation of doors, interiors, windows, outer walls and roofs (City of Kyoto, 2016a).

Cities can provide technical assistance and knowledge sharing to improve energy efficiency. Munich provides technical and management advice to local companies on how to save energy, raw materials and water through ÖKOPROFIT (Ecological Project for Integrated Environment Technology). The goal is to improve energy efficiency in their facilities, to reduce their ecological footprint and to reduce their energy expenses (City of Munich, 2010).

Regulatory policy tools are provided by governments, and energy-efficiency standards for housing and buildings are set out in national requirements. Some cities actively improve energy efficiency in newly constructed and existing buildings by enforcing strong local energy standards. Munich has adopted city-wide construction requirements for energy that are higher than national standards (City of Munich, 2010). In Toronto, the "Toronto Green Standard" makes it mandatory for the design of new buildings to incorporate high energy conservation standards. At least $15 \%$ energy efficiency improvement over the current Ontario Building code needs to be achieved (City of Toronto, 
2015c). Some cities adopt the policy of charging large energy consumers. For example, large public and private organisations in Bristol have to purchase allowances according to the rate of their $\mathrm{CO}_{2}$ emissions, through the "Carbon Reduction Commitment" (CRC) (Bristol City Council, 2013b). Barcelona has a similar scheme, since Endesa SAU, the city's major energy provider, levies penalties on large energy consumers.

\section{Energy self-sufficient housing, buildings and districts}

Some cities are promoting measures towards energy self-sufficient housing, buildings and districts that aim to produce energy onsite. Connection to the national grids is promoted by laws in force in the OECD countries generally, and the development of local electricity grids is either restricted or is not subject to any subsidies. This is the case for the energy policy implemented in the Netherlands that rewarded suppliers for undertaking quality and quantity empowerments, but not for promoting local grids (OECD, 2010). On-site generation and local energy networks are, however, becoming popular. Local energy networks are more efficient, as they can minimise energy transmission loss and promote the resilience of urban energy supplies in extreme weather events (City of Toronto, n.d.e). On-site generation and local energy networks can be found in the concept of built environment at various spatial scales including zero-energy housing and building, and energy selfsufficient urban districts. Kyoto offers assistance to individuals who construct new housing with independent and decentralised energy-generating systems, including home energy management systems (HEMS), residential solar electricity, electrical storage devices, solar heating and fuel cells (City of Kyoto, 2015d).

Barcelona's energy planning aims to increase self-sufficiency of the city by decreasing energy demand, producing local renewable energy and optimising infrastructure (Table 10). The aim is to convert buildings into real power plants by integrating renewable energy installations within them (Barcelona City Council, 2012). Buildings are planned to be able to independently produce and export energy to other buildings within a block (Barcelona City Council and Barcelona Energy Agency, 2013). Barcelona is also developing district heating networks and residual energy systems to achieve energy self-sufficiency. The first and largest urban network in Spain is the Districlima system, which has enabled the city to save more than $50 \mathrm{GWh}$ of primary energy and approximately 10000 tonnes of $\mathrm{CO}_{2}$. A new district heating system, the EcoEnergies system is also being developed to connect all suitable municipal buildings to the grid (Barcelona City Council, n.d.g). 
Table 10. Barcelona's Energy Self-Sufficiency Plan

\section{Objectives, scope and scenarios}

core areas of implementation of proposals and control elements

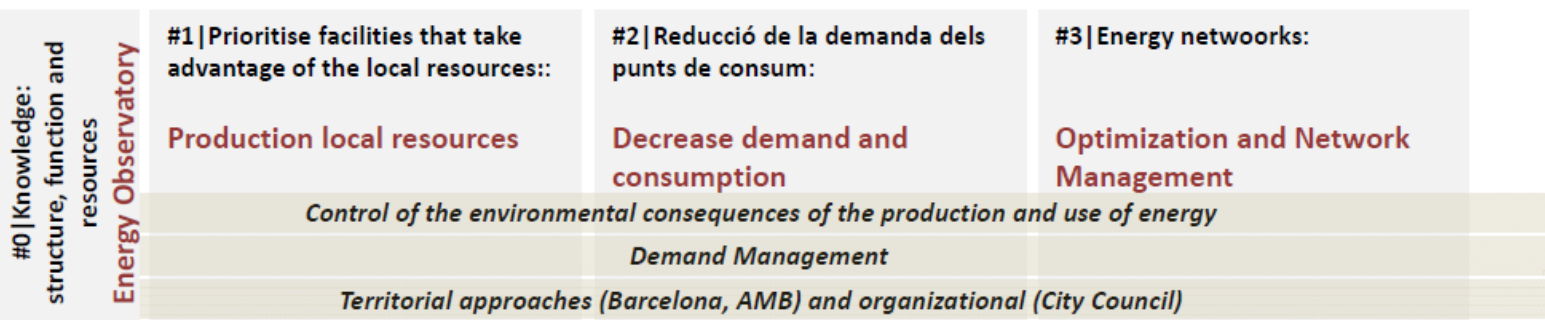

sectors and actuation vectors
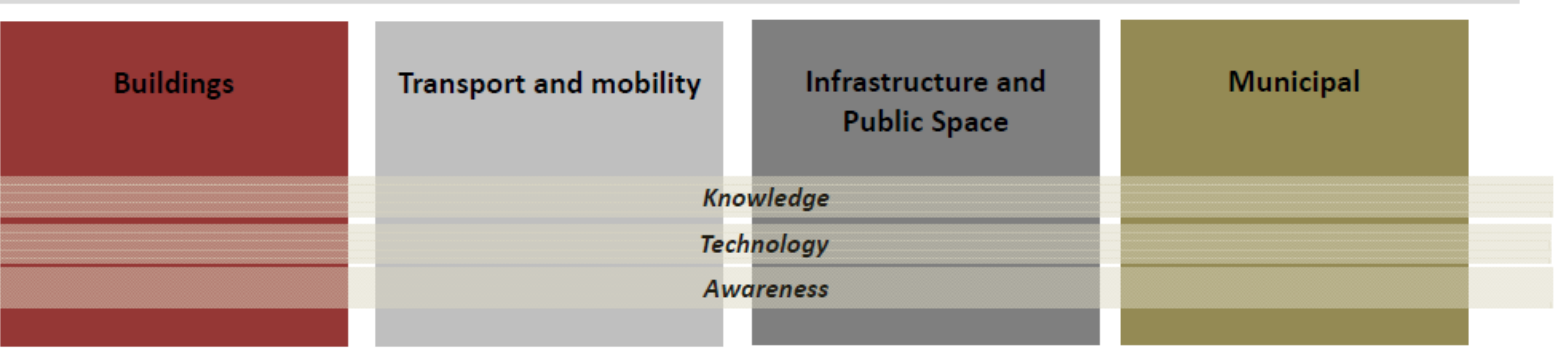

Main temporary milestones

2020: $20 \%$ reduction in final energy consumption compared to 2008
2050: strategic approach to achieve 2050 goals

Source: Barcelona City Council and Barcelona Energy Agency (2013), "Barcelona Energy Self-Sufficiency Plan" (brochure),(April), available at: http://www.energy-cities.eu/IMG/pdf/Barcelona-Energy-Agency Irma-Soldevilla.pdf.

Toronto is expanding its district energy systems mainly in the centre and north of the city centre (Figure 25) to create more decentralised local energy solutions to address growth at the source (City of Toronto, n.d.e). District energy has already been installed in Toronto for 100 years, and many of the city's organisations, including colleges and hospitals, have their own systems. New opportunities to connect buildings to district energy exist and have been developed through "Community Energy Planning" (City of Toronto, n.d.b). This programme is a neighbourhood-scale strategy to promote low carbon energy solutions in the city. The aim is to address growth and economic development early in the land use process, to maximise the long-term benefits. Local residents, community groups, cooperatives and other local organisations are the stakeholders in this programme. Some districts, including the city centre, avenues and areas with rapid growth, are the particular focus (City of Toronto, n.d.b). Since 2004, Enwave Energy Corporation (partly owned by the city) has developed a deep-water cooling system from the Lake Ontario that provides 75000 tonnes of refrigeration (equivalent to $263 \mathrm{MW}$ ) directly to enterprises established in the city (City of Toronto, 2015c). 
Figure 25. Existing District Energy Systems and Potential for New Systems in Toronto

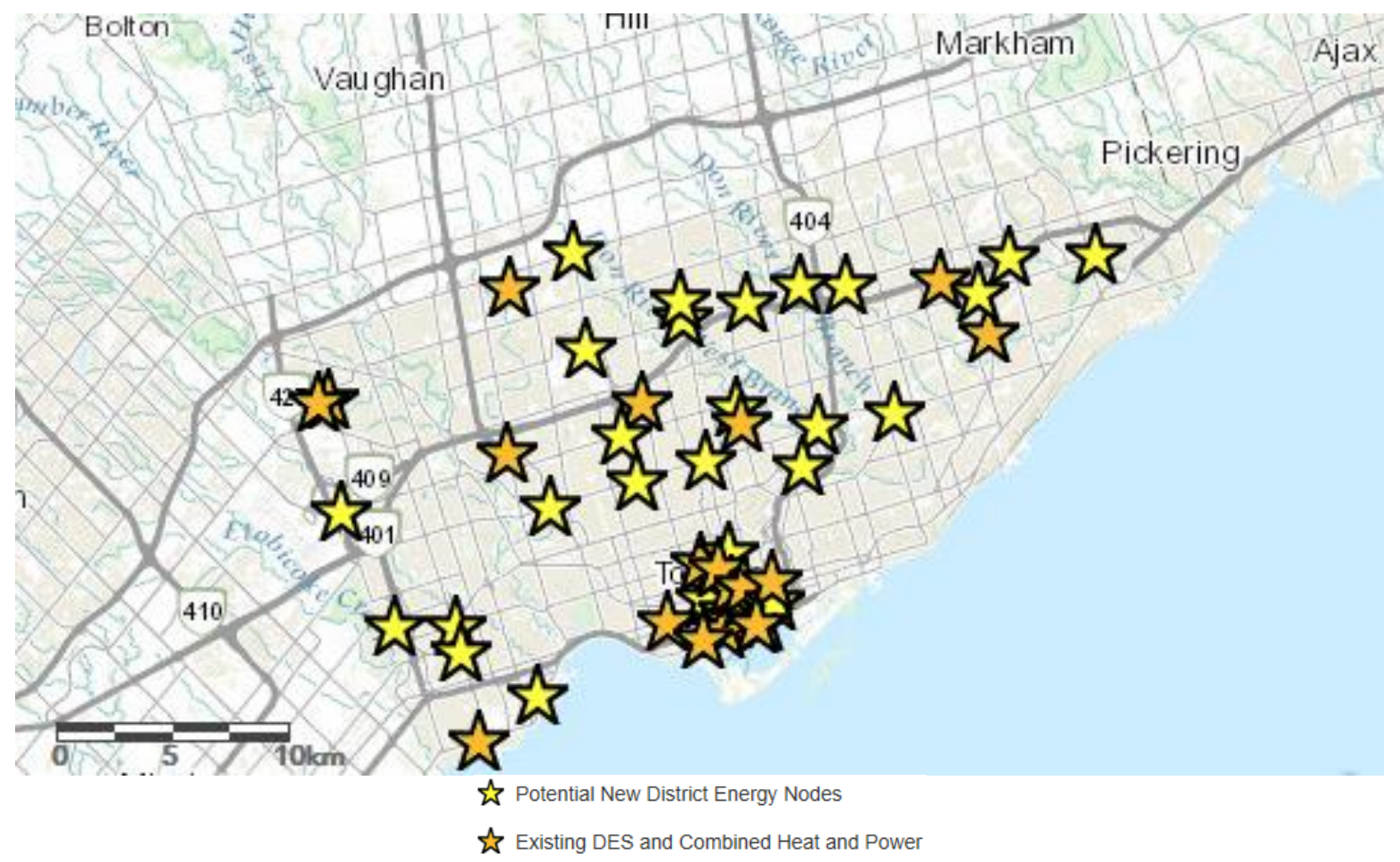

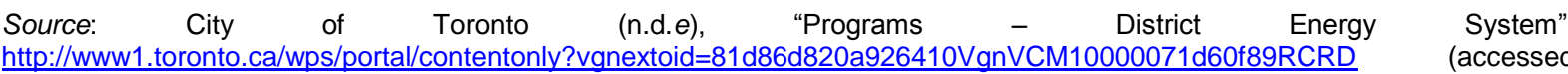
September 2015).

Energy self-sufficient housing, buildings and districts can help absorb shocks to urban energy supply. For example, during the wide energy disruptions of the Great East Japan Earthquake, one of the urban blocks in Tokyo not only sustained energy supply in the area but also provided electricity to the electric power company (Cabinet Office, 2011b). The urban district has its own energy plant, operated by its energy company, which provides electricity, hot water, cooling and heating on site.

Energy consumption and production in cities are affected by urban development projects, which influence residential patterns and urban functions. These can present opportunities to redevelop and modernise urban energy infrastructure, and can be closely co-ordinated with energy management. 


\section{Box 7. Zero-energy building}

The energy balance of buildings and housing can be reduced to close to zero by reducing energy consumption and increasing the use of renewable energy. Various examples can be found in several countries, although no internationally common definition has been identified.

The European Union defines "nearly zero-energy building" in Directive 2010/31/EU of the European Parliament and Council, dated 19 May 2010. This is described as a building with high energy performance, as determined under the framework for the calculation of energy performance of buildings set out in the Annex of the Directive. The very low amount of energy required should be covered to a significant extent by energy from renewable sources, including energy from renewable sources produced on site or nearby. Member states are required to ensure that $i$ ) by 31 December 2020, all new buildings be nearly zero-energy buildings; and ii) that after 31 December 2018, new buildings occupied and owned by public authorities be nearly zero-energy (European Parliament and Council of European Union, 2010).

In the US, the term "zero-net-energy commercial building" is defined in "Net-Zero Energy Commercial Buildings Initiative" based on "Energy Independence and Security Act Of 2007" as a high-performance commercial building that is designed, constructed and operated $i$ ) to require a greatly reduced quantity of energy to operate; $i$ i) to meet the balance of energy needs from sources of energy that do not produce greenhouse gases; iii) in a manner that will result in no net emissions of greenhouse gases; and $i v$ ) to be economically viable. The goal of the initiative shall be to develop and disseminate technologies, practices and policies for the development and establishment of zero net energy commercial buildings for $i$ ) any commercial building newly constructed in the United States by 2030 ; ii) $50 \%$ of the commercial building stock of the United States by 2040; and iii) all commercial buildings in the United States by 2050 (Energy Independence and Security Act of 2007; Authenticated U.S Government information, 2010).

In Japan, a definition of zero-energy building (ZEB) appears in the Japanese government report on a study group for the implementation and deployment of ZEB. ZEB is defined as the building annual primary energy consumption is a net of zero or nearly zero by reducing primary energy consumption through methods including improvement of energy efficiency of buildings and equipment, regionally energy use, and utilisation of renewable energy on site. The national government sets its target as follows: realise ZEB by 2020 for newly constructed public buildings and by 2030 for average of newly constructed public buildings (METI, 2009).

Source: European Parliament and Council of the European Union (2010), "Directive 2010/31/EU of the European Parliament and the Council of 19 May 2010 on the energy performance of buildings (recast) [2010] OJ L153/13", available at: http://eurlex.europa.eu/LexUriServ/LexUriServ.do?uri=OJ:L:2010:153:0013:0035:EN:PDF; Energy Independence and Security Act of 2007, Pub. L. No 110-140, 121 Stat. 1492 (2007), Washington, DC, available at: http://www.gpo.gov/fdsys/pkg/PLAW110publ140/pdf/PLAW-110publ140.pdf; Authenticated U.S. government information (2010), "U.S. Code § 17082 - Zero Net Energy Commercial Buildings Initiative", Authenticated U.S. government information, Washington DC, available at: http://www.gpo.gov/fdsys/pkg/USCODE-2010-title42/pdf/USCODE-2010-title42-chap152-subchaplll-partB-sec17082.pdf; Ministry of Economy, Trade and Industry, Japan (2009), "Realisation and development of ZEB", Ministry of Economy, Trade and Industry, Tokyo, available at: http://www.meti.go.jp/report/downloadfiles/g91124d01j.pdf.

\subsubsection{Increasing renewable energy production in cities}

Currently, renewable energy deployment and production in urban areas is limited by comparison with rural areas. However, urban areas also have great potential for producing renewable energy, as shown in Chapter 1. Some cities are aware of the importance of preparing for disruptions in energy 
supplies. Kyoto, for example, has a large population and receives 50 million visitors annually from Japan and abroad. Guaranteeing public safety and security is thus of the utmost importance to the city. Approximately $16 \%$ of city-owned facilities, including the local and regional evacuation facilities involved in the Kyoto Area Disaster Prevention Plan, have installed renewable energy equipment (City of Kyoto, 2013a). The city has made progress in installing renewable energy resources that contribute to strengthening its disaster prevention and response. For example, storage batteries and renewable energy sources have been installed as emergency power systems at disaster prevention centres and evacuation facilities.

Cities are also encouraging individuals and the private sector to install additional renewable energy equipment. In Toronto, the "Toronto Solar Neighbourhoods" initiative provides financial incentives to local residents to install solar hot water systems (City of Toronto, 2009). In the first phase of the project, 150 systems are planned for installation in houses in the specific districts, before being implemented in the whole city. The "Recoverable Debt Program" also addresses citizens who intend to produce their own green energy. Through this programme, the Toronto Renewable Energy Office (TREO) provides long-term loans to residents to support the difference between renewable and convention energy costs that can be paid back within 20 years (City of Toronto, 2013). The City of Munich provides a programme to promote solar installations for local companies. The Förderprogramm Energieeinsparung (FES - Munich Energy Conservation Incentive Programme) has been active since 1989 and provided EUR 14 million in 2015 to encourage local enterprises to implement energy saving activities and self-generation of heat (City of Munich, 2010). Solar panels are subsidised at EUR 200 per square metre of installed collection area on urban roofs.

Information regarding renewable energy potential is provided to facilitate the efforts of individuals and the private sector. Barcelona aims to exploit its maximum potential of solar energy production and encourages citizens to install solar PV where feasible, by providing information and financial and technical support. Solar thermal power is the main source of renewables in Barcelona, accounting for about half of the total local production of renewable energy. An online map shows $20 \%$ of accessible rooftops in the city are suitable for solar panels, and could, if fully exploited, produce 400000 MWh per year for hot water or electricity (Barcelona City Council, n.d.h). Barcelona's Solar Thermal Ordinance (2000) made it mandatory to incorporate solar systems to heat water in newly built and renovated buildings. In 2012, $81021 \mathrm{~m}^{2}$ of solar installations were installed, most in residential buildings and hotels. Munich also provides an online solar potential map, which indicates usable roof space for solar PV and solar thermal systems. The map provides a calculation of the solar electricity and heat potential for each building in the city, as well as details on possible $\mathrm{CO}_{2}$ savings (City of Munich, n.d.c). Conducting feasibility assessments of solar panel installations is mandatory for all new building construction and renovation of existing buildings of the city administration, and local authorities in Munich assess the potential of renewable energy production in the city.

Cities are also developing renewable energy infrastructure, including district energy (cooling and heating), geothermal system (cooling and heating), biomass and biogas. Toronto has developed renewable energy infrastructure of this kind to reduce its dependency on natural gas (City of Toronto, 2013). The city constructs renewable energy plants, with at least 35 facilities already in place and 64 planned for construction (City of Toronto, 2014a), including solar roofs and deep-lake water-cooling facilities. Munich is expanding its renewable energy sources to improve co-ordination between energy infrastructure and urban development. The municipality-owned energy utility company Stadtwerke München $\mathrm{GmbH}$ (SWM) supports the rehabilitation of residential areas, notably through its district heating project, which aims to power the district heating system entirely with green energy by 2040 . Munich aims to extend the current 800-kilometre network by 100 additional kilometres (Figure 26), to increase the total capacity of district heating by $10 \mathrm{MW}$ within ten years, and EUR 200 million has been invested in this high-priority project (SWM, 2015b). 
Figure 26. Munich's district heating system

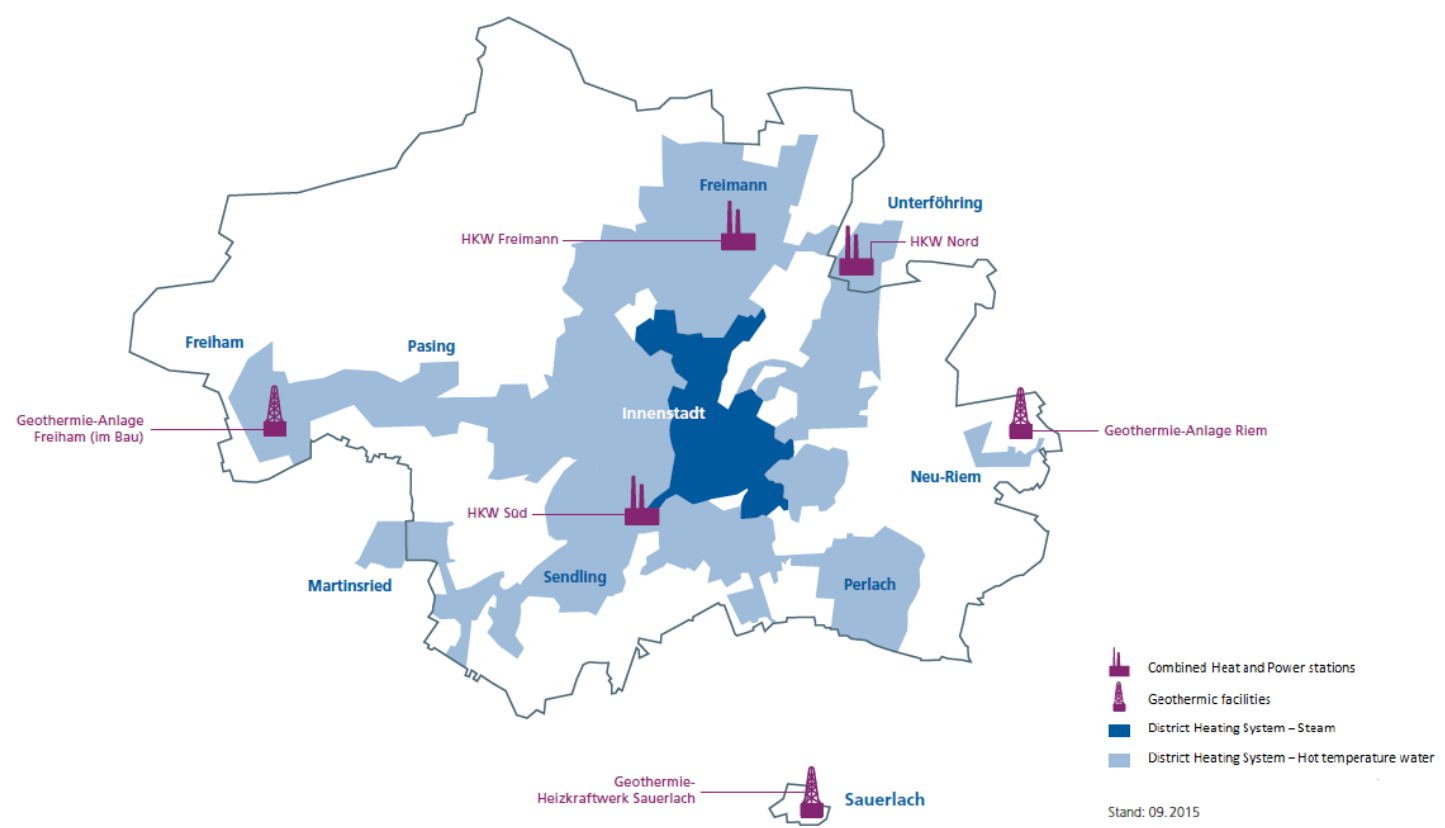

Source: SWM (2016b), https://www.swm.de/english.html (accessed May 2016).

Renewable energy deployment is a key feature of urban planning. Urban planning determines land use and the location of the facilities and urban development projects in a city, which influence the use of energy and the installation of RE facilities. Perpignan has a local urban planning (PLU) which includes land-use planning and regulations covering the physical environment considering renewable energy deployment. Upon the revision of the PLU, the city analysed the impact of urban planning on GHG emissions, including compact urbanisation and urban expansion, with a testing tool, GES PLU (a GHG assessment tool). As a result, local authorities chose not to expand urbanisation to new areas. Regarding electricity distribution, Perpignan promotes the idea of energy autonomy. Connection to the national grid is still mandatory for small-scale systems in France, but discussions are still under way at the national and local levels over the use of locally produced renewable energies for household consumption. Studies on the potential for district heating are recommended in Integrated Development Zones (ZAC).

Some cities face conflicts between renewable energy deployment and urban design. For example, solar panels are occasionally thought to be unsightly. Kyoto has many traditional buildings of 1200 years old designated as World Heritage sites, and is strongly committed to conservation policies. Rooftop preservation is an important element of these policies, and the installation of solar panels is restricted in some areas. The city enforces installation standards for solar panels, along with other restrictions, including their colour (City of Kyoto, 2013d). Solar panels are subject to the regulations governing landscape policy in some cities (Table 11). In Perpignan, as in any other French city, city council authorisation is required for elements in bioclimatic design (e.g. solar shading) and for renewable energy production (e.g. selection of solar thermal or PV). Perpignan's historical city centre is listed as a protected area by interministerial decree. Strict design controls are in place in the historical area of the city, which, for instance, restrict the installation of solar panels. The city is currently working to revise the regulation of the protected area to provide more flexibility in the regulations and thus to make it easier to install solar panels. Barcelona aims to upgrade renewable energy production and introduce new technologies within the city, while preserving its historical buildings (Barcelona City Council, 2012). Renewable facilities, including solar thermal, solar PV 
panels and mini-wind turbines, are designed so that they can be efficiently integrated in historical buildings.

Table 11. Regulatory requirements for solar panels by sub-national governments in Japan

\begin{tabular}{|l|r|r|}
\hline & Prefectures & Municipalities \\
\hline Landscape ordinance & 2 & 1 \\
\hline Landscape plan & 1 & 6 \\
\hline Natural environment conservation ordinance & 1 & 2 \\
\hline Administrative guidelines, standards, etc. & 2 & 12 \\
\hline
\end{tabular}

Source: Own calculation based on MOE, Ministry of the Environment, Japan (2014), "Requirements for solar panels by local governments", Ministry of anvironment, http://www.env.go.jp/nature/mega solar na/conf/h2601/mat05 1.pdf.

\subsubsection{Public transport and green mobility}

The transport sector offers rich opportunities for smart energy management in the urban environment, since its share of energy consumption has been increasing, as shown in Figure 26. Monitoring energy consumption and emissions from the transport sector is fundamental for identifying challenges in energy and environment at the local level. Perpignan Méditerranée estimates GHG emissions by sector, which indicates that personal transport and merchandise transport account for nearly half of the GHG emissions (Figure 27). Perpignan city accounts for $40 \%$ of the conurbation's emissions and its merchandising transport is the primary polluter (Perpignan Méditerranée, 2012).

Figure 27. GHG emissions by sector in Perpignan (2012)

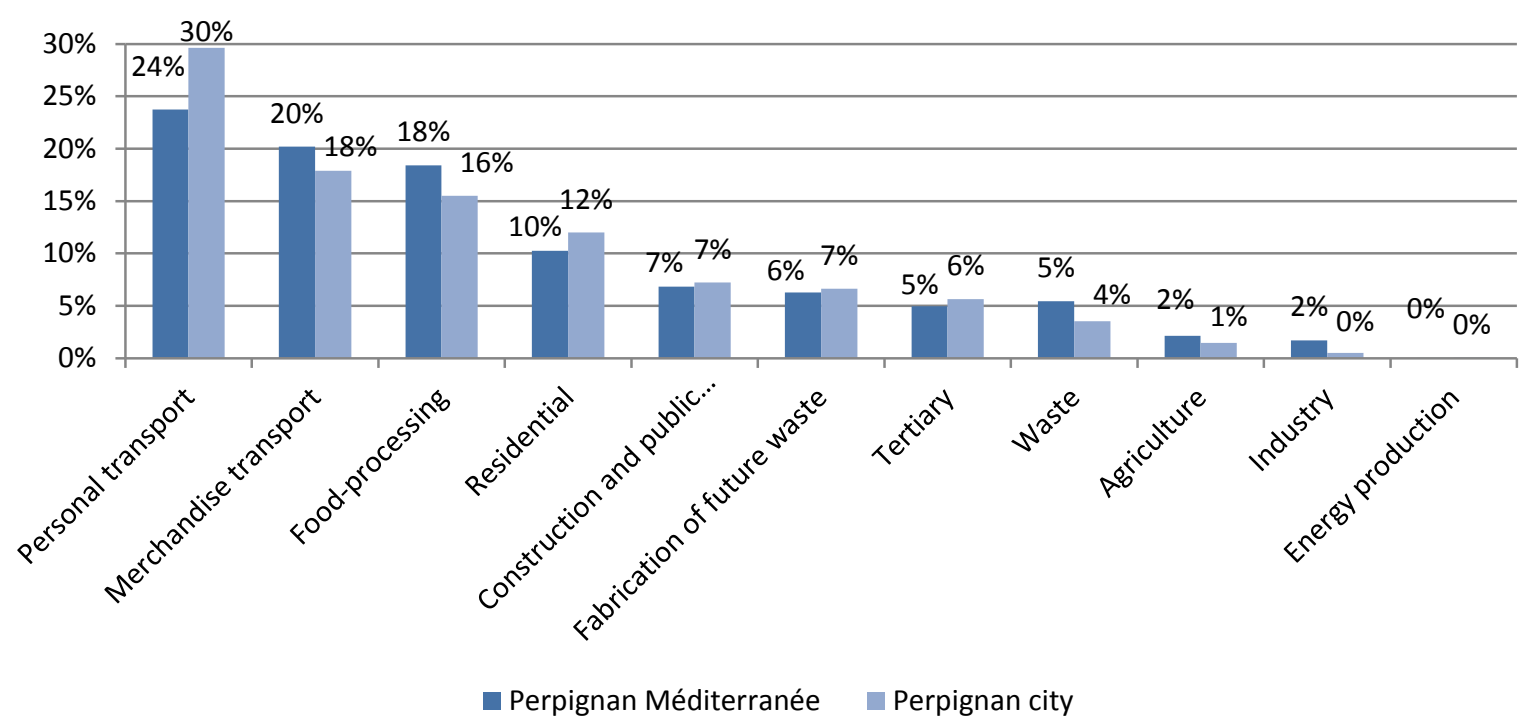

Source: Based on data from Perpignan Méditerranée (2012), "Plan Climat-Énergie Territorial de PMCA et de Perpignan 20122017' 'Territorial Climate-Energy Plan of PMCA and Perpignan 2012-2017], (September), available at: http://agenda21perpignanmediterranee.com/wp-content/uploads/plan-climat-perpignan-pmca.pdf.

Energy policy in cities needs to assess the energy efficiency and environmental impact of each transport mode. In OECD countries, road transport accounts for the most part of the total energy consumption in the sector (Figure 28). Private automobiles have a far larger energy consumption than rail, bus and domestic navigation, as shown in Japan (Figure 29). Utilising green mobility and 
promoting the shift from private vehicles to public transport are some effective solutions. Investing in green mobility and adopting a "green growth" approach entails developing new economic activities, notably in high-tech. This can help create jobs and increase a city's level of productivity, unlocking growth potential (Banister, Crist and Perkins, 2015).

Barcelona adopted its Mobility Law in 2003 and began to achieve more efficient and inclusive mobility thanks to three urban planning schemes: the Mobility Master Plan of the Metropolitan Region of Barcelona (PDM), the Urban Mobility Plan of Barcelona (PMU) and the Infrastructure Master Plan (PDI). Public transport is at the core of the strategy, both as regards efficiency and expansion. The city council committed to meet $95 \%$ of the growth in mobility with public and other clean means of traveling by 2018 (Barcelona City Council, n.d.a). The city has developed a network of around 500 recharging points for green vehicles in the city, through the LIVE Platform (Logistics for the Implementation of Electric Vehicles) project, which is funded by both public and private organisations (Barcelona City Council, n.d.g). Toronto's "Smart Commute" programme incorporates energy policy into city planning. It helps employers reduce their environmental impact by providing their employees sustainable ways to commute (City of Toronto, n.d.c), including carpooling and cycling. As of 2014, the programme involved 96 firms in the city, representing 331000 commuters (City of Toronto, 2015c). In addition to the numerous programmes designed by the Toronto Transit Commission that aim at greening transport within the city, Toronto authorities have tried to concentrate urban population growth in areas that provide sustainable transport options (City of Toronto, 2015c). As a result of these efforts, commuting to work by car as a transport mode fell by $8 \%$ between 2001 and 2011 (City of Toronto, 2015c). Munich has implemented a low-emission zone in its city centre since 2008. All vehicles (from buses to automobiles and trucks) are classified according to their particulate emissions and receive a sticker (red, yellow or green) indicating which category they belong to, which determines whether they are allowed to enter the city centre. Access is denied to high-emission vehicles (red and yellow) (City of Munich, 2014c).

Increasing the accessibility of public transport can be achieved through better co-ordination of transport planning and urban development planning. Kyoto's master plan declares that the city aims to create an eco-compact urban form, to increase urban vitality and realise a low-carbon society. The plan also states that the city will attempt to concentrate urban functions at public transport centres, for instance businesses at rail stations and industries along trunk roads. In addition, the city aims to reduce reliance on automobiles by enhancing public transport and improving access to the city centre (City of Kyoto, 2013e). 
Figure 28. Breakdown of final energy consumption in the transport sector in OECD countries (2013)

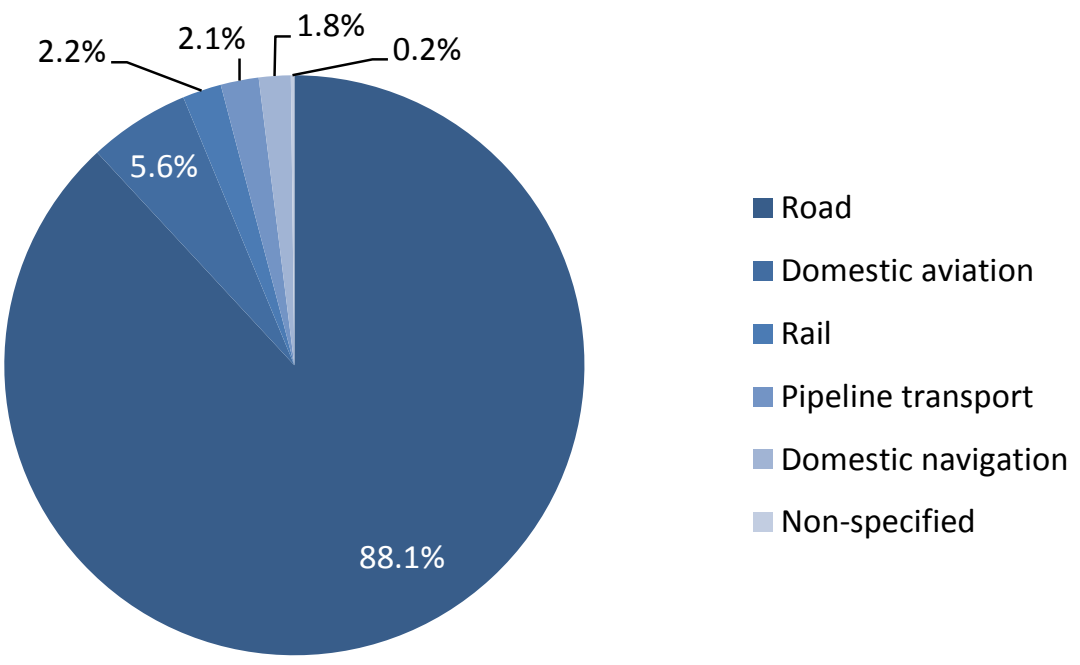

Source: Based on data from OECD (2015e), "OECD.Stat”, OECD, Paris, http://stats.oecd.org/ (accessed 3 December 2015).

Figure 29. Energy consumption per unit by transport mode, Japan, 2009

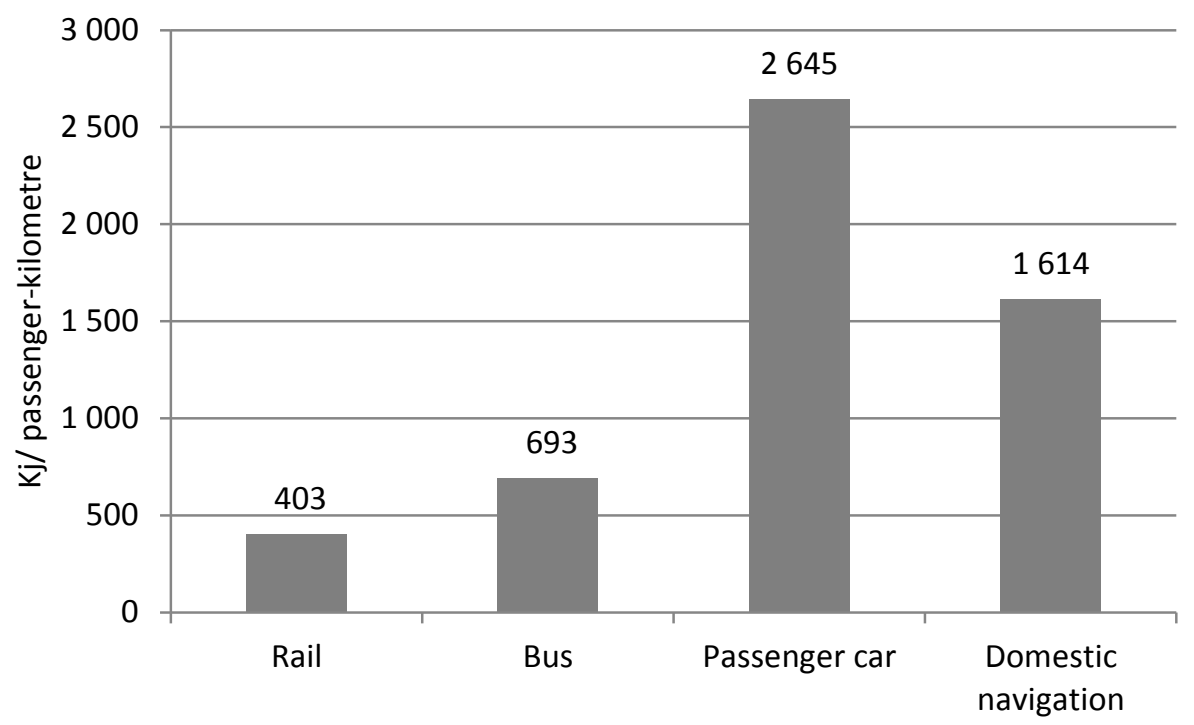

Source: Based on data from Ministry of Land, Infrastructure, Transport and Tourism, Japan (2012), "Transportation Statistics" Ministry of Land, Infrastructure, Transport and Tourism, Tokyo, http://www.mlit.go.jp/statistics/kotsusiryo.html (accessed 18 December 2015). 


\subsection{Finance}

Finance policies at the national and local level should be aligned with climate goals and should foster investment in smart energy management, to promote a transition towards a low-carbon economy that ensures more sustainable and more resilient growth (OECD, 2015f). Financing for energy management requires new sources of financing (OECD, 2015f) and involves capital from various financial institutions, including mortgage financing, household and co-operative loans (Table 12). The most common source is self-financing from savings, revenues or tax revenues. Next to self-financing, households depend mainly on loans. In industry, most efficiency improvements are conducted as part of business activity, and specific financing models are not required. Public investment in climateresilient projects is key in the initial stages (OECD, 2015g). But in a context of public finance constraints, and given that financing energy efficiency requires large-scale investment and entails various hurdles and risks, the private sector should also be given a significant role in financing smart energy management projects (OECD, 2015h). Energy efficiency, for example, is a cost-effective investment, and the investor must bank not on an asset producing a cash flow, but on the expectation of future cost savings. Energy efficiency projects are fragmented into many small projects and have high transaction costs (IEA, 2014b). To overcome these market barriers and unlock private investment - notably from international institutional investors including insurance companies or pension funds several instruments are made available to policy makers (OECD, 2015g). First, they can use risk mitigation tools that distribute the risk effectively, to enhance the appeal of green investments, including revenue guarantees, insurance products, credit enhancement and public stakes. Second, high transaction costs can be counteracted through transaction enablers, such as warehousing (i.e. pooling small transactions together) or securitisation mechanisms (i.e. transforming illiquid assets into tradable securities). Collaboration and co-investment among investors can also be a valuable way to offset market barriers (OECD, 2015g).

Table 12. Financing methods for energy-efficiency projects

\begin{tabular}{|c|c|c|c|c|}
\hline & Market segment & Typical project size & Repayment method & Market penetration \\
\hline Self-financing & All & Unlimited & - & High \\
\hline Consumer loan & $\begin{array}{l}\text { Transport, } \\
\text { households }\end{array}$ & $\begin{array}{l}\text { USD } 1000 \text { to } \\
\text { USD } 20000\end{array}$ & $\begin{array}{l}\text { Credit card bill, loan } \\
\text { payment }\end{array}$ & High \\
\hline $\begin{array}{l}\text { Energy savings } \\
\text { performance } \\
\text { contract }\end{array}$ & Services, industry & $\begin{array}{l}\text { USD } 0.5 \text { million - } \\
\text { unlimited }\end{array}$ & Service contract & Medium \\
\hline $\begin{array}{ll}\text { Energy } & \text { service } \\
\text { agreement } & \\
\end{array}$ & Services, industry & $\begin{array}{l}\text { USD } 250000 \text { to } \\
\text { USD } 10 \text { million }\end{array}$ & $\begin{array}{l}\text { Terms of service } \\
\text { agreement }\end{array}$ & Low \\
\hline $\begin{array}{l}\text { Property assessed } \\
\text { clean energy }\end{array}$ & Services, industry & $\begin{array}{l}\text { USD } 2000 \text { to } \\
\text { USD } 2.5 \text { million }\end{array}$ & Property tax bill & Low \\
\hline $\begin{array}{l}\text { Utility on-bill } \\
\text { financing }\end{array}$ & $\begin{array}{l}\text { Households, } \\
\text { services, industry }\end{array}$ & $\begin{array}{l}\text { USD } 5000 \text { to } \\
\text { USD } 350000\end{array}$ & Utility bill & Low \\
\hline $\begin{array}{ll}\text { Public } & \text { loan } \\
\text { programmes } & \\
\text { (syndicated } & \\
\text { loans/grants) } & \end{array}$ & All & $\begin{array}{l}\text { USD } 1000 \text { to } \\
\text { USD } 10 \text { million }\end{array}$ & $\begin{array}{l}\text { Loan payment, } \\
\text { none for grants }\end{array}$ & Medium \\
\hline $\begin{array}{l}\text { Mortgage-backed } \\
\text { finance }\end{array}$ & $\begin{array}{l}\text { Households, } \\
\text { services }\end{array}$ & $\begin{array}{l}\text { USD } 2000 \text { to } \\
\text { USD } 25000\end{array}$ & Mortgage & Low \\
\hline
\end{tabular}


Various levels of governments provide schemes to finance smart energy management in cities (Table 13). Funds from diverse sources are used for financial resources of local authorities to implement urban energy policies, including municipal renewable energy plant projects and financial assistance for citizens to install renewable energy equipment.

National governments provide finance schemes to promote their energy policies. France's "Green Innovation Funding: Investments for the Future" has been managed by the ADEME (Agence de l'environnement et de la maîtrise de l'énergie) since 2010 (IEA, 2015b). This initiative encompasses several financing tools for SMEs, intermediate-size and large enterprises, as well as research laboratories. The aim is to increase market penetration of renewables and to invest in smart grids for promoting job creation and restoring the country's competitiveness. Canada's central government established the "Clean Energy Fund" (IEA, 2015b) to finance pilot projects led by either for-profit or not-for-profit organisations in energy-related fields in 2009. Energy projects should address the issues related to the institutional difficulties of smart energy management, including availability, reliability and cost-effectiveness of the renewable technologies to be financed through the fund. The UK's "Green Deal" scheme, started in 2013, encourages communities and individual consumers to generate their own clean energy. Loans granted by energy providers allow them to undertake relevant work compensated for by future savings in their energy bills (IEA, 2015b).

National governments also provide finance for sub-national governments. The UK's "Contract for Difference" (CfD) is a tool used by local authorities to develop their own renewable power plants. CfD counterparties deliver subsidies to the electricity generator at the amount of the difference between the energy market price and a negotiated price between the different stakeholders. In case of a lower strike price, the generator has to refund the difference to the counterparty (IEA, 2015b). Bristol benefits from the national feed-in tariff scheme implemented by the central government in 2010 that enables the city to obtain revenues from its own generation of green electricity. Barcelona benefits from its Energy Saving and Diversification Investment Fund, developed by the national government in 2014 to finance sustainable development projects in urban areas. Eligible projects may be either public or private and can be led by energy service companies (ESCOs) or other firms (IEA, 2015b).

Cities have financing schemes, including loans and bonds, depending on whether the national legislation in each country allows municipal borrowing to finance investment or public expenditure (OECD, 2013), to conduct their own urban energy projects. At an early stage of development, a new instrument is beginning to emerge that specifically finances projects to create a low-carbon and climate-resilient economy: the "green bond". Green bonds are fixed-income debt securities issued to raise capital from institutional investors, and dedicated to financing green projects (The World Bank Treasury, 2009). They are a means for governments to attract and to steer investments toward environmental projects (OECD, 2013). Some cities, including Chicago, issue their own green bonds to finance renewable energies and energy-efficiency projects. In most cases, however, green bonds are only viable for cities if they co-operate closely with national governments to compensate for their higher default risk and their lower credit ratings (OECD, 2013). The green bond market is most developed in the United States, Canada and in Scandinavian countries. Toronto can benefit from two green bonds programmes launched by the province of Ontario in October 2014 and January 2016. Ontario is the first province in Canada to issue green bonds, and uses them across its municipalities to finance several projects, including energy efficiency and conservation in urban buildings, and climateresilient and environmental-friendly infrastructure (Ontario Financing Authority, 2016). For example, the deep-lake water cooling system developed by Enwave was financed by the issue of public and private bonds (City of Toronto, 2015c). Loan programmes are also a significant method for local authorities to finance energy projects. For instance, Bristol's Salix Scheme, established in 2004, funds its energy projects with interest-free loans to the public sector, and 200 projects were supported, with a total value of GBP 3 million (Salix Finance, 2015). Renewable energy and energy efficiency measures 
help reduce the city's energy bill. These are returned to the fund, then reused to finance other energy projects.

Cities provide grants and subsidies to promote their urban energy policies. Bristol promotes community-based investment in renewables through its Community Programme (Energy Service Bristol City Council, 2015) (Figure 30), under which solar PV panels and other renewable technologies are owned and managed by local community energy groups. These groups may be local energy companies, or co-operatives of local residents willing to invest in renewable projects in their community. The fact that the installations of renewable technologies are managed by local residents ensures that the benefits of local production of energy remain in the community. The incentives for citizens to invest in such projects are that they will experience a positive return on investment. The deployment of green electricity can reduce their energy bills in the medium term. The programme raised approximately GBP 1 million in 2015. Kyoto implements the Kyoto Civic Co-operation Power Generation Scheme, which encourages the installation of solar power generators in co-operation with local citizens, so as to rapidly expand the use of solar energy (City of Kyoto, 2013f). In this scheme, the city has designated the roofs of city facilities as places where solar power generation facilities can be set up, and it provides access to these roofs at no charge to organisations working on environmental practices. These organisations install and manage solar-power-generating equipment with the investments that they have received from participating citizens, and the revenue earned from selling the energy generated to power companies is returned to their investors. The organisations also make other contributions to society, including holding meetings on environmental science. As of 2015, they had an operational output of $388.7 \mathrm{~kW}$ of electricity (City of Kyoto, 2015e).

Figure 30. Bristol's Community Programme

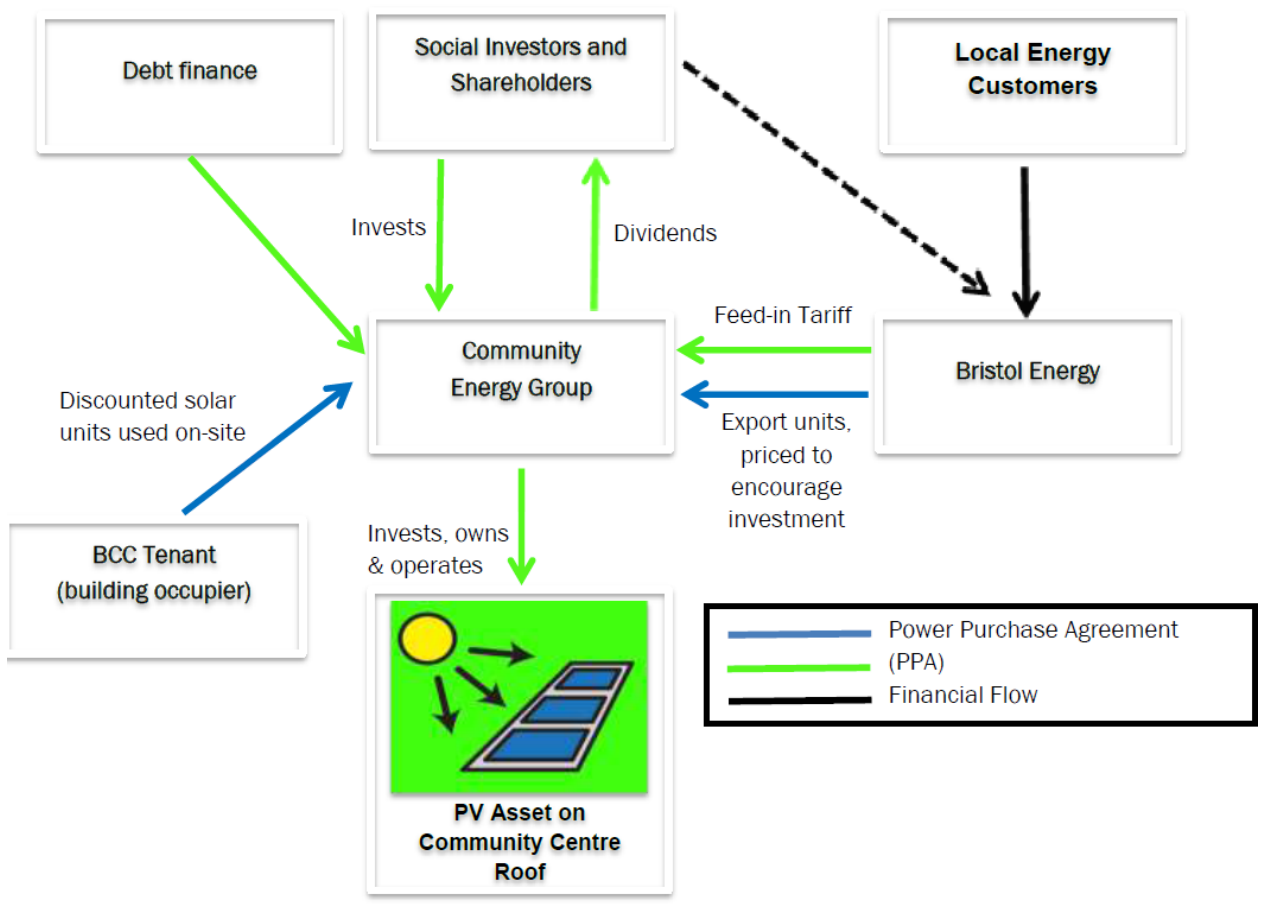

Source: Energy Service, Bristol City Council (2015), "Community Energy - Competition Public Briefing" (brochure), available at: https://www.bristol.gov.uk/documents/20182/33776/Community Energy Competition Brief May 2015 0.pdf/6e3e9466-2dfe-47cabe40-a1f74594e2d3h (accessed September 2015). 
Table 13. Finance schemes for urban energy management by governments

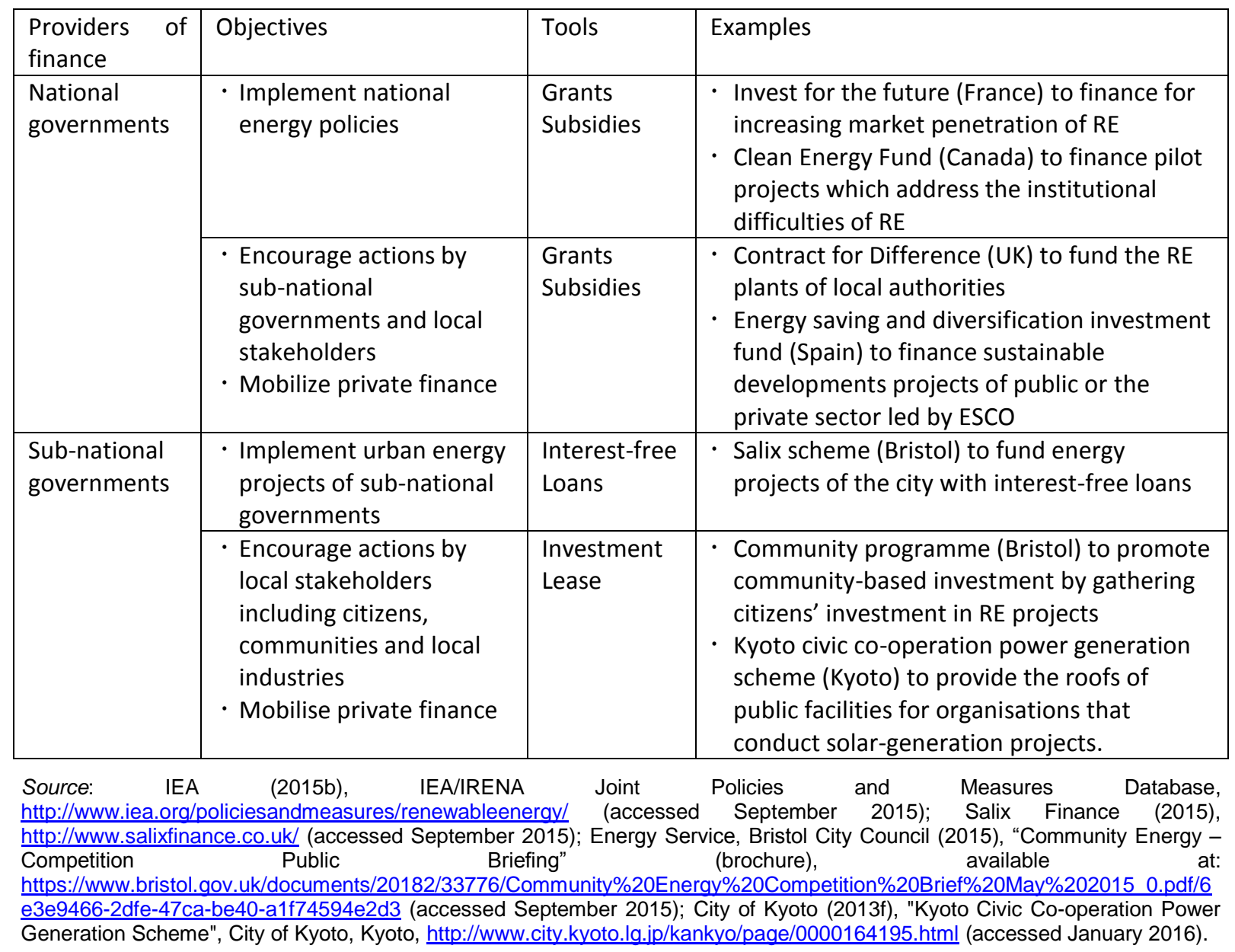

Financial instruments can be effective when combined with regulatory policy instruments. Governments have "carrot and stick" policies that combine financial support (the carrot) with regulations (the stick) to further incentivise of the private sector. For example, governments negotiate long-term agreements on energy efficiency with industry and offer benefits including highly energy efficient machinery supported by green taxes and accelerated depreciation schemes, in order to motivate companies to replace machinery for energy efficiency (EEFIG, 2015). Project development assistance and incentives develop demand when combined with the enforcement of existing regulations, the transposition of EU Directives and complementary policies on energy savings (EEFIG, 2015). In these respects, better co-ordination between financial assistance and regulatory tools at both national and local levels is key to efficient energy management. 


\subsection{Institutional capacities}

Cities cannot become resilient without adequate institutional and governance systems. Potential for resilience is limited unless appropriate regulations are established and enforced. Civic participation is a challenge without active policies for citizen engagement by local government (OECD, 2015a). This section analyses policy practices for enhancing institutional capacity through collaboration among stakeholders, raising awareness of energy efficiency between citizens and creating alliances between cities.

\subsubsection{Collaboration between stakeholders including industry, academia and governments}

Cities are expected to provide effective solutions for energy management through policy design, implementation and procurement. Such efforts include collecting information on good practices and making use of adequate technologies. The institutional capacity of city governments, however, is not always adequate for keeping up with cutting-edge technologies and incorporating best practices. Collaboration with the stakeholders who have the appropriate knowledge and technical skills can contribute to the urban energy policies implemented by city governments.

Cities collaborate with academia and industries to develop new technologies on energy management. For example, Kyoto has an "Urban Oilfield" development project to manufacture ethanol through co-operation between the government, industry and academia. This project uses paper and food waste discarded by residences and factories to produce an alternative to petroleum fuel. Subsidies are also available to SMEs for their research and development expenses related to environmental and energy issues, to make such endeavours more practical and marketable (City of Kyoto, 2014). These subsidies, together with administrative organs, financial institutions, economic groups, universities and organisations that promote innovation, are working to manufacture new fuels from the carbon dioxide emitted into the air. These groups are also co-operating to create a system to chemically store electricity; to develop key raw materials for fuel cells including catalysts and hydrogen-generating agents; and to develop technology for saving energy by changing direct current (DC) to alternating current (AC) using semiconductor power elements (City of Kyoto, 2015f).

Cities may partner with various relevant stakeholders to pursue a sustainability strategy. For example, energy and climate issues mobilise a large range of actors across the society in Barcelona, especially through their common engagement in the "Compromís 22 - Commitment towards Sustainability 2012-2022". This co-operation platform gathers 800 stakeholders under the name "Barcelona + Sustainability", from professional associations to universities, trade unions and businesses. They share best practices and resources and receive training to green their activities. In 2012, they committed to ten sustainability goals and to implement 100 concrete actions (Barcelona City Council, n.d.i). Barcelona also benefits from the cluster Campus Diagonal-Besòs, and its Energy Park, which groups companies and research institutes from the energy sector to promote co-operation, innovation and economic activity in the fields of energy, water and transport management (Barcelona City Council, n.d.g). Beyond stakeholders' involvement in smart energy management, Barcelona also encourages them to participate in the policy decision-making process, with 900 stakeholders from different sectors participating in the design of the PECQ (Energy, Climate Change and Air Quality Plan of Barcelona) in several sessions, web sessions and working groups.

\subsubsection{Raising awareness of energy efficiency among citizens}

Citizens are key actors for place-based actions of urban energy management, given that they are both energy consumers and stakeholders in energy policies in their cities and communities. However, individuals are not perfectly rational (Gillingham et al., 2009). Their energy consumption habits may 
result in ineffectiveness of conventional energy policies and distorted financial incentives (Maréchal, 2009). A survey shows that $27 \%$ of the inhabitants in Barcelona are comfortable with environmental problems, meaning that they are not active enough in reducing their ecological footprint (Barcelona City Council, n.d.a). Raising awareness of energy efficiency among citizens is therefore important to change such behaviour. Such issues can be addressed by information programmes (Gillingham et al., 2009). Policies that introduce energy efficiency actions as "challenges" to be taken on by citizens, as well as programmes that make public the energy performance of the members of a community, are more effective because they stimulate individuals' values and motivation (Maréchal, 2009). Citizens' involvement can take diverse forms, including energy conservation, choice of green energy and participation in policy making.

Cities can also enlist their citizens in the policy-making process. For example, Perpignan Méditerranée holds a council for monitoring and assessing (Conseil de Suivi et d'Evaluation) that consists of inhabitants, representatives of sustainable development associations and company managers. This council participated in the design of the Climate and Energy Plan and delivered 116 citizen recommendations and forecasts, spanning 2012-2015 (Perpignan Méditerranée, 2012). Barcelona involves citizens in its Citizen Council for Sustainability. This was established in 2014 in an attempt to make groups throughout society into active stakeholders in the policy-decision process. The council promotes engagement and shared responsibility, and enables citizens to discuss initiatives, to find new solutions, and to assess the programmes implemented (Barcelona City Council, n.d.j). In Bristol, documents related to energy strategies have to be made publicly available, and the city regularly performs assessment reports of environmental policies (Bristol City Council, 2014).

Cities encourage their communities to participate in energy management. Kyoto's "eco-school district" project provides the communities with the materials useful for community activities, lecture classes on ecology and global warming issues, opportunities to participate in activities to learn energy conservation tips, and to consult with experts by submitting a declaration. The school districts work on eco-friendly activities, including renewable energy deployment, through the project. The city supports school districts to encourage all districts to participate in the project (City of Kyoto, 2016b). The Miyako Anshin Sumai Centre also provides a one-stop service for citizens for submitting applications and obtaining information on technologies and subsidies for installing solar power generation systems and fuel-cell systems for houses, renovating existing houses to improve energy efficiency and HEMS (Miyako Anshin Sumai Centre, n.d.). To spread knowledge about energy issues, the city of Perpignan organises the Nuits de la Thermographie (Thermography Nights) to raise public consciousness about energy waste in buildings. Perpignan Méditerranée Communauté Urbaine promotes public debate on energy issues: once a year, citizens gather to watch movies on relevant topics and exchange ideas.

The Bristol Energy Network focuses on actions of citizens and community energy groups to promote projects on renewable energy and energy efficiency. Citizens can involve in energy actions through community groups including the Easton Energy Group and "Future Fit Bristol" programmes, composed of residents working in the field of energy. They provide free advice to their neighbours on energy efficiency measures and convey information on municipal policy tools that are available (Bristol City Council, n.d.d). Bristol also develops communication with children in schools. The Bristol Green Capital Official Schools Programme helps teachers to introduce sustainability and energy issues in the curriculum to inculcate this ethos in children (Bristol 2015, 2015d).

\subsubsection{Creating alliances between cities}

While individual cities have the capacity to enhance their urban resilience through their energy policy, using the city as the unit for urban energy management presents some challenges. For example, spatial scales for smart energy management of existing energy supply chains may extend beyond 
administrative boundaries. Obstacles to the deployment of renewable energy in large cities include the extent of their energy consumption, their physical environment and the conditions of land use. Some cities try to overcome these issues by entering into partnerships with other cities.

Collaborative visions and targets for urban energy policy can create synergies. Cities of the conurbation joined forces within an intercommunal organisation (Perpignan Méditerranée Communauté Urbaine), to capitalise on the area's varying assets in terms of energy consumption and renewable energy production. The planned mix of energy sources includes a large wind farm park installed in the conurbation, which is to cover $31 \%$ of the area's residential electricity consumption. The park is not established on the territory of Perpignan. Land suitable for the construction of the park is difficult to find in the city of Perpignan itself, because of constraints including the location of the airport. Perpignan itself accounts for approximately $40 \%$ of the population and $40 \%$ of total emissions of Perpignan Méditerranée. Involving neighbouring cities in the project can also benefit the surrounding cities by creating job opportunities in the latest renewable technologies. The cities and the conurbation are working together to create synergies between the two levels of governments.

Creating alliances can help cities implement urban energy policies efficiently and effectively, with ramifications for national governments and other stakeholders. Kyoto is in the Kansai region, which has set up the Union of Kansai Governments, established by seven prefectures and four ordinance-designated cities. This organisation is working on issues including the expansion of renewable energy, the creation of a low-carbon society and wide area disaster-management measures that extend beyond individual prefectures. The Union of Kansai Governments' Energy Investigative Commission has adopted a Kansai Energy Plan, which includes the goal of creating a total of 6 million $\mathrm{kW}$ of renewable energy (4.5 million $\mathrm{kW}$ of solar power) in 2020 (Union of Kansai Governments, 2014). The organisation is encouraging the deployment of renewable energy suitable to the individual region, as well as information sharing among the member prefectures and cities. The large ordinance-designated cities under the Local Autonomy Act have established a "Designated City Council on Renewable Energy" as a result of the energy supply issues that arose after the Great East Japan Earthquake (Designated City Council on Renewable Energy, 2011). The member cities are major energy consumers, and have taken the initiative to expand their use of renewable and decentralised energy by making the maximum use of regional characteristics. The mayor of Kyoto, who serves as the president of the council, promotes policies of sustainability through developing renewable energy, for instance by submitting recommendations on renewable energy policy to the national government. 


\subsection{Pilot projects}

Pilot projects enable cities to identify challenges, test the feasibility and estimate the effects of cutting-edge energy technologies. Many stakeholders and investments are mobilised in the pilot projects. For example, Perpignan Méditerranée has developed the "Catalan Ecopark" (Perpignan Méditerranée, n.d.b), which includes a wind farm, a photovoltaic solar plant, a heat network, a waste energy plant and a biogas production unit. The target of the project is to cover $40 \%$ of the electricity demand in Perpignan Méditerranée by 2016. The project period is scheduled from 2009 to 2016 and represents an investment of around EUR 200 million. Various private firms, as well as the city of Perpignan and Perpignan Méditerranée, are involved in the project. The wind farm has been constructed by EDF Energies Nouvelles (the renewable energy branch of the French electricity company EDF), with EUR 140 million invested. The waste energy plant is a project led by the TIRU Group, a French firm specialised in waste treatment, while biogas production is the responsibility of SITA, an arm of Suez Environment, which specialises in waste treatment. The solar energy plant has been constructed by the Compagnie du Vent (a branch of Engie, formerly GDF Suez), which specialises in wind power.

Pilot projects are carried out in particular areas before city-wide policies are implemented. Kyoto has been conducting a study on urban development to improve the city's energy management, including efficiency, comfort, safety and security. The study has been conducting with the Smart City Kyoto Research Association (a co-operative association including industry, academia and government), utilising information and communication technologies (ICT). The city has been installing building energy management systems (BEMS) designed to optimise the renewable energy obtained in a single building from independent, decentralised means of power generation in the Okazaki area. It is also piloting a community energy management system (CEMS) that networks these facilities to optimise energy use in an entire community (City of Kyoto, 2015g).

\section{Box 8. Energy management systems in housing, building and cities}

Managing energy demand and supply in housing, building and cities can be optimised with ICT. BEMS promotes and facilitates energy demand management for building by using IT technology. It ensures real-time management of energy or load according to real-time information in buildings, through optimisation of lighting and air conditioning. HEMS (home energy management systems) also incorporate IT networks, using information on energy supply and use of appliances and hot water equipment in housing. It allows for automated monitoring and display of energy use information, and thus promotes energy conservation (IEA, 2015c). CEMS intends to optimise energy management by networking BEMS, HEMS, RE equipment and other relevant facilities at the community level.

Source: IEA (2015c), "Promotion of Home Energy Management System (HEMS), Building Energy Management System (BEMS)", International Energy Agency, Paris, available at: http://www.iea.org/policiesandmeasures/pams/japan/name-22420en.php.

Barcelona City Council has collaborated on the Municipal Urban Landscape Institute (IMPU) in implementing the "Intervention Plan of Dividing Faces" (2012-2014) (Barcelona City Council and Barcelona Energy Agency, 2013). The programme's goal was to integrate renewable energy facilities in the facades of buildings. Pilot projects have been developed in the city's new innovation and business centre - the "22@" area. EUR 57000 was invested in the municipal archives' building (Mitgera 22@_Ciutat de Granada), whose solar panels can generate $21000 \mathrm{kWh}$ per year, with an 
installed capacity of $18 \mathrm{~kW}$. EUR 48000 was also invested in solar PV installations for a private building in the same area (Mitgera 22@_Pujades), to produce $11500 \mathrm{kWh}$ per year, with an installed capacity of $10 \mathrm{~kW}$.

Pilot projects give lessons for cities in choosing feasible and effective measures. Munich's municipal-owned utility company Stadtwerke München GmbH (SWM) launched its "Renewable Energies Expansion Campaign" in 2008 for a major development of several sources of renewable electricity mainly in other parts of Germany and not within the city. Several green energy plants have been constructed, including two geothermal plants, 21 solar power stations and 3400 solar panels that produced 32.769 MWh of electricity in 2013. This campaign revealed that wind energy was the most cost-efficient source of renewable energy, prompting the city to plan to increase the share of wind energy in its municipal energy mix. Due to its favourable location for geothermal activity, this source of renewable heat energy will play a growing role in the Munich. Currently, two geothermal plants have been built by Stadtwerke München. The third geothermal plant will come onstream in 2016. 


\section{CONCLUSIONS}

Energy management is likely to play an ever-increasing role as the demand for energy increases. Cities' success in energy policy can contribute to the well-being of urban residents, and to achieving national energy policy objectives and national growth. National governments as well as sub-national governments thus have a significant role to play in establishing and implementing energy policies in cities. Drawing on the previous chapters and on the drivers and building blocks of a resilient city (Box 1), this chapter outlines key policy strategies for managing energy smartly in cities to build resilience (Table 14).

\section{Adaptive energy management}

An adaptive approach to energy management manages uncertainty in an urban energy system by helping it to evolve: modifying standards, norms and past behaviour and using evidence to identify solutions and apply knowledge gained from past experience in making decisions about the future. Mainstreaming energy management in urban policy is the key for achieving this objective. A longterm perspective for energy management is needed in urban policy, since the physical environment of cities develops over an extended timeframe. Moreover, a cross-cutting and comprehensive viewpoint is needed, since energy consumption and supply intersects with policies in various fields, including economic development plans, land-use planning and transport planning. Cities are also expected to incorporate national policies and international frameworks into local action, since building resilience requires action on a global level. Kyoto City's "Strategy for Promoting Energy Policy (2013)" is a good example, as it is reflected in other programmes and policies, including its measures to combat global warming. Measuring energy data at the city level helps cities to understand the current state of resources, to set targets and to analyse policy impacts. Energy data and indicators need to be clear, easy to understand and appropriate for setting targets, establishing policies and tracking the impact of policies in the long term.

\section{Robust energy management}

Robust energy management can help absorb shocks and emerge unscathed or without significant loss to its capacity to function. Its robustness can be measured by the magnitude of shock the system can successfully absorb, and depends on well-designed, built and managed physical assets. Improvement of energy infrastructure is fundamental in reducing the risk of damages from unexpected natural disasters and shocks. Appropriate maintenance, disaster management and updating are fundamental means for reducing energy disruptions, but there are cost issues. Urban redevelopment projects are one strategy, offering the opportunity to update and to introduce the latest technology. Developing energy self-sufficient housing, buildings and urban blocks can help stabilise energy supply to vital urban facilities in times of emergency. For example, Barcelona aims to increase self-sufficiency through energy planning, to decrease energy demand, to produce local renewable energy and to optimise infrastructure. Involving consumers in developing such housing, buildings and urban blocks is important, and policy instruments, including the regulatory system and financial support, need to be effective to encourage their efforts.

\section{Redundant energy management}

Redundant energy management can help meet the need for extra capacity when faced with unexpected demand, a disruptive event or extreme pressures. This means intentionally developing or having access to more than one source of action, service or service provider when necessary. Diversity 
in energy management, including sources, methods and source areas, can equip cities to respond to risks, including energy price fluctuations, disasters and accidents. A decentralised energy system has the advantage of ensuring energy supply during major energy disruptions and reducing energy losses in delivery. This strategy, however, has its challenges, including economies of scale and stability of supply. Cities' energy strategies should thus combine centralised and decentralised energy systems appropriately. Finance schemes for smart energy management need to be effective to encourage investment from various parties, and take into consideration what renewable energy projects will entail, including high transaction costs and the expectation of future savings. For example, the decision to issue green bonds for energy efficiency in Ontario province in Canada generated projects including light rail transport with high environmental performance.

\section{Flexible energy management}

Flexible energy management allows individuals, households, businesses, communities and government to adjust their behaviour or actions to respond to changes in energy demand and supply. A long-term vision, combined with a mid-term strategic implementation plan, is important for flexible energy management, so that goals can be reached in accordance with unexpected circumstances, including fluctuations in demand arising from social and economic changes, as well as changes in energy demand and supply structure. Toronto City's "Climate Change, Clean Air and Sustainable Energy Action Plan" (2007) is a good example. Pilot projects implemented over a limited area and time period can contribute to flexible energy management by identifying problems, assessing the feasibility of a project and quantifying the effects of innovative measures in advance. Careful selection of projects and evaluation methodologies is key.

\section{Resourceful energy management}

Resourceful energy management restores the functionality of essential services and systems effectively and quickly in a crisis or under highly constrained conditions. This can optimise the resources available, meeting a city's needs, maintaining its purpose and achieving its aims in times of shock or stress. Increasing renewable energy production in cities can contribute to this objective in the conditions of economically and technically efficient by enhancing local energy supply in a crisis. Given that the physical environment influences energy demand, energy efficiency and the potential of renewable energy production, urban policies need to be co-ordinated with energy management. Enhancing the energy efficiency of housing and buildings can reduce the pressure on resources. The life cycle of housing and buildings involves various parties, including those involved in construction, use and demolition, so multiple measures, including regulatory standards, and financial and technical support are required. Effective urban transport policies, including high-efficiency transport and better co-ordination of urban development and transport planning, are also key elements in resourceful energy management. Barcelona's "Urban Mobility Plan (2014)" is a good example.

\section{Inclusive energy management}

Inclusive energy management ensures that diverse actors and communities are fully consulted, engaged and empowered in the policy process, bringing diverse perspectives together. Collaboration between industries, institutions of higher education and governments is necessary to achieve this objective. Governments need to keep abreast of the latest technologies and approaches. Cities therefore need to mobilise resources from industry and academia and to co-ordinate various stakeholders to adapt and integrate pioneering policies. Raising awareness of energy efficiency among citizens can enhance energy management in citizens' daily life, and enlist their participation in the energy effort. Cities, as parties close to the daily lives of citizens, can give citizens more precise guidance by considering local conditions. For example, Kyoto City encourages its communities to 
participate in energy management by providing the communities with materials and lecture classes, as well as consultation with experts, through the "eco-school district" project.

\section{Integrated energy management}

Integrated energy management can help promote a co-operative and collaborative approach to policy and programming, to ensure coherent decisions and effective investment. Creating alliances between cities is the key for developing an effective and efficient energy supply and demand structure at the regional level. This can complement cities' particular urban conditions. A large city with high energy consumption and limited potential for renewable energy production might form a partnership with smaller cities that wish to develop renewable energy production to boost the local economy. Perpignan's 2008 strategic vision, with the goal of becoming a positive energy territory, is a good example. Creating alliances between cities can also contribute to knowledge sharing and lobbying on energy issues by networking cities with similar visions. In creating these alliances, visions of the cities, the existing governance structures of the cities and other factors, including the functional urban area (FUA) need to be taken into account in designing better governance arrangements for smart energy management.

Table 14. Key policy strategies of energy management for building resilience in cities

\begin{tabular}{|c|c|c|c|}
\hline \multirow[t]{2}{*}{ Building blocks } & \multirow[t]{2}{*}{ Key policy measures } & \multicolumn{2}{|l|}{ Key roles } \\
\hline & & National government & Sub-national government \\
\hline \multirow[t]{2}{*}{$\begin{array}{l}\text { Adaptive } \\
\text { energy } \\
\text { management }\end{array}$} & $\begin{array}{l}\text { Mainstreaming energy } \\
\text { management in urban } \\
\text { policy }\end{array}$ & $\begin{array}{l}\text { - Support and promote sub- } \\
\text { national governments to make } \\
\text { urban policy that mainstreams } \\
\text { energy management }\end{array}$ & $\begin{array}{l}\text { Develop an urban policy that } \\
\text { integrates urban } \\
\text { development and energy } \\
\text { management } \\
\text { - Improve the coherence of } \\
\text { various sectoral policies } \\
\text { regarding energy in cities }\end{array}$ \\
\hline & $\begin{array}{l}\text { Measuring energy data } \\
\text { at city level }\end{array}$ & $\begin{array}{l}\text { - Develop and provide } \\
\text { methodology for measuring } \\
\text { energy data at city level } \\
\text { - Develop an energy database } \\
\text { at city level }\end{array}$ & $\begin{array}{l}\text { - Estimate and measure energy } \\
\text { data at city level } \\
\text { - Utilise the data for policy } \\
\text { making and measuring policy } \\
\text { impacts }\end{array}$ \\
\hline \multirow[t]{2}{*}{$\begin{array}{l}\text { Robust } \\
\text { energy } \\
\text { management }\end{array}$} & $\begin{array}{l}\text { Improvement of energy } \\
\text { infrastructure }\end{array}$ & $\begin{array}{l}\text { - Develop a national energy } \\
\text { infrastructure improvement } \\
\text { strategy }\end{array}$ & $\begin{array}{ll}\text { - } & \text { Develop energy } \\
\text { infrastructure improvement } \\
\text { strategy at local level }\end{array}$ \\
\hline & $\begin{array}{l}\text { Developing energy self- } \\
\text { sufficient housing, } \\
\text { buildings and urban } \\
\text { blocks }\end{array}$ & $\begin{array}{l}\text { - Encourage the private sector } \\
\text { to develop energy self- } \\
\text { sufficient housing, buildings } \\
\text { and urban blocks through } \\
\text { economic policy tools, } \\
\text { technical assistance and } \\
\text { regulatory policy tools }\end{array}$ & $\begin{array}{l}\text { Develop local energy } \\
\text { planning, including energy } \\
\text { management of housing, } \\
\text { buildings and urban blocks } \\
\text { for building resilience in cities }\end{array}$ \\
\hline
\end{tabular}


Table 14. Key policy strategies of energy management for building resilience in cities (cont.)

\begin{tabular}{|c|c|c|c|}
\hline \multirow[t]{2}{*}{$\begin{array}{l}\text { Redundant } \\
\text { energy } \\
\text { management }\end{array}$} & $\begin{array}{l}\text { Diversity in energy } \\
\text { management }\end{array}$ & $\begin{array}{l}\text { - Better co-ordinate energy mix } \\
\text { in national energy policy }\end{array}$ & $\begin{array}{l}\text { Develop local energy } \\
\text { planning, taking into account } \\
\text { both the current situation } \\
\text { and the future prospects for } \\
\text { the energy mix }\end{array}$ \\
\hline & $\begin{array}{l}\text { Effective finance } \\
\text { schemes for smart } \\
\text { energy management }\end{array}$ & $\begin{array}{l}\text { - Review and reform relevant } \\
\text { financing schemes }\end{array}$ & $\begin{array}{l}\text { Develop and improve finance } \\
\text { schemes for the projects of } \\
\text { sub-national government, } \\
\text { encouraging actions by local } \\
\text { stakeholders and mobilising } \\
\text { private finance }\end{array}$ \\
\hline \multirow[t]{2}{*}{$\begin{array}{l}\text { Flexible } \\
\text { energy } \\
\text { management }\end{array}$} & $\begin{array}{l}\text { Long-term vision with a } \\
\text { mid-term strategic } \\
\text { implementation plan }\end{array}$ & $\begin{array}{l}\text { - Develop a national long-term } \\
\text { vision with a mid-term } \\
\text { strategic implementation plan } \\
\text { for energy management } \\
\text { - Support and promote sub- } \\
\text { national governments to } \\
\text { develop a long-term vision }\end{array}$ & $\begin{array}{l}\text { Develop a long-term vision } \\
\text { with mid-term strategic } \\
\text { implementation plan at the } \\
\text { local level }\end{array}$ \\
\hline & $\begin{array}{l}\text { Implementing pilot } \\
\text { projects }\end{array}$ & $\begin{array}{l}\text { - Support sub-national } \\
\text { governments in setting up } \\
\text { pilot projects }\end{array}$ & $\begin{array}{l}\text { Launch pilot projects to } \\
\text { identify problems, assess the } \\
\text { feasibility and quantify the } \\
\text { effects of innovative } \\
\text { measures }\end{array}$ \\
\hline \multirow[t]{3}{*}{$\begin{array}{l}\text { Resourceful } \\
\text { energy } \\
\text { management }\end{array}$} & $\begin{array}{l}\text { Improving energy } \\
\text { efficiency of housing } \\
\text { and buildings }\end{array}$ & $\begin{array}{l}\text { - Improve energy efficiency of } \\
\text { national government buildings } \\
\text { and relevant public facilities } \\
\text { - Encourage the private sector } \\
\text { to improve energy efficiency } \\
\text { of housing and buildings } \\
\text { through economic policy } \\
\text { tools, technical assistance and } \\
\text { regulatory policy tools }\end{array}$ & $\begin{array}{l}\text { - Improve energy efficiency of } \\
\text { sub-national government } \\
\text { buildings and relevant public } \\
\text { facilities } \\
\text { - Promote the private sector to } \\
\text { improve energy efficiency of } \\
\text { housing and buildings } \\
\text { considering local conditions }\end{array}$ \\
\hline & $\begin{array}{l}\text { Increasing RE } \\
\text { production in cities if it } \\
\text { proves economically } \\
\text { and technically efficient }\end{array}$ & $\begin{array}{l}\text { - Develop a national policy } \\
\text { framework for RE production } \\
\text { at local level } \\
\text { - Encourage the private sector } \\
\text { to optimise RE production in } \\
\text { cities through economic policy } \\
\text { tools, technical assistance and } \\
\text { regulatory policy tools }\end{array}$ & $\begin{array}{l}\text { - Estimate potential of RE in } \\
\text { cities } \\
\text { - Assess economical and } \\
\text { technical efficiency of RE } \\
\text { production in cities } \\
\text { - Develop RE production } \\
\text { facilities through direct } \\
\text { investment and encouraging } \\
\text { the private sector } \\
\end{array}$ \\
\hline & $\begin{array}{l}\text { Effective urban } \\
\text { transport policies }\end{array}$ & $\begin{array}{l}\text { - Support and promote sub- } \\
\text { national governments to } \\
\text { develop better urban } \\
\text { transport policies }\end{array}$ & $\begin{array}{l}\text { Develop and improve urban } \\
\text { transport plans, based on } \\
\text { energy efficiency } \\
\text { - Co-ordinate transport } \\
\text { planning, land use and urban } \\
\text { development }\end{array}$ \\
\hline
\end{tabular}


Table 14. Key policy strategies of energy management for building resilience in cities (cont.)

\begin{tabular}{|c|c|c|c|}
\hline \multirow[t]{2}{*}{$\begin{array}{l}\text { Inclusive } \\
\text { energy } \\
\text { management }\end{array}$} & $\begin{array}{l}\text { Collaboration among } \\
\text { industries, academia } \\
\text { and governments }\end{array}$ & $\begin{array}{l}\text { - Provide information on } \\
\text { practices of collaboration } \\
\text { between industries, academia } \\
\text { and governments at local level }\end{array}$ & $\begin{array}{l}\text { - Collaborate with academia } \\
\text { and industries to develop } \\
\text { new technologies for energy } \\
\text { management } \\
\text { - Partner with various } \\
\text { stakeholders to pursue a } \\
\text { sustainability strategy }\end{array}$ \\
\hline & $\begin{array}{l}\text { Raising awareness of } \\
\text { energy efficiency among } \\
\text { citizens }\end{array}$ & $\begin{array}{l}\text { - Raise awareness of energy } \\
\text { efficiency among citizens } \\
\text { through national campaigns }\end{array}$ & $\begin{array}{l}\text { - Raise awareness of energy } \\
\text { efficiency among citizens for } \\
\text { place-based actions } \\
\text { - Enlist citizens in the policy- } \\
\text { making process } \\
\text { - Encourage communities to } \\
\text { participate in energy } \\
\text { management }\end{array}$ \\
\hline $\begin{array}{l}\text { Integrated } \\
\text { energy } \\
\text { management }\end{array}$ & $\begin{array}{l}\text { Creating alliances } \\
\text { among cities }\end{array}$ & $\begin{array}{l}\text { - Provide information on } \\
\text { practices of alliances between } \\
\text { cities }\end{array}$ & $\begin{array}{l}\text { - Create alliances between } \\
\text { cities to complement cities' } \\
\text { differing situations } \\
\text { - Create alliances between } \\
\text { cities for knowledge sharing } \\
\text { and lobbying }\end{array}$ \\
\hline
\end{tabular}




\begin{abstract}
ANNEX A GLOSSARY
Energy: The capacity for doing work, as measured by the capability of doing work or the conversion of this capability into motion (EIA, n.d.). Energy sources include solid, liquid and gaseous fuels; electricity; uranium; steam and hot water; and traditional fuels including fuel, wood, charcoal, vegetal and animal waste (OECD, n.d.b).

Energy consumption: The use of energy as a source of heat or power or as a raw material input to a manufacturing process (EIA, n.d.). Primary energy consumption refers to the direct use at the source or supply to users, without transformation of crude energy, that is, energy that has not been subjected to any conversion or transformation process (OECD, n.d.b). Total final consumption refers to the sum of consumption by the different end-use sectors. It is broken down into energy demand in the following sectors: industry, transport, buildings (including residential and services) and other (including agriculture and non-energy use) (IEA, 2016).
\end{abstract}

Energy demand: The requirement for energy as an input to provide products and/or services (EIA, n.d.). Total primary energy demand represents domestic demand only and is broken down into power generation, other energy sectors and total final consumption (IEA, 2016).

Energy production: Primary production of energy is any extraction of energy products in a usable form from natural sources. This occurs either when natural sources are exploited or in the fabrication of biofuels. Transforming energy from one form into another, such as electricity or heat generation in thermal power plants, or coke production in coke ovens, is not primary production (European Commission, 2014b).

Energy supply: Energy made available for future disposal (EIA, n.d.). Total primary energy supply, equivalent to total primary energy demand, represents inland demand only, and except for world energy demand, excludes international marine and aviation bunkers (IEA, 2016).

Smart energy management: As set out in this paper, smart energy management implies managing energy to build resilience in cities, through measures including improvement of energy efficiency and the deployment of renewable energy.

Source: OECD (n.d.b), "Glossary of statistical terms", OECD, Paris, https://stats.oecd.org/glossary/ (accessed January 2016); EIA, US Department of Energy (n.d.), "Glossary", https://www.eia.gov/tools/glossary/index.cfm, Washington, DC (accessed January 2016); IEA (2016), "Glossary", https://www.iea.org/aboutus/glossary/; European Commission (2014b), "Thematic glossaries", Brussels, http://ec.europa.eu/eurostat/statistics-explained/index.php/Thematic glossaries. 


\section{BIBLIOGRAPHY}

Agency for Natural Resources and Energy (2014a), "Energy consumption statistics by prefecture", Tokyo, http://www.enecho.meti.go.jp/statistics/energy_consumption/ec002/results.html\#headline2 (accessed 27 March 2015).

Agency for Natural Resources and Energy (2014b), "Website for information of Feed-in tariff”, Tokyo, http://www.fit.go.jp/statistics/public_sp.html (accessed 27 March 2015).

Agency for Natural Resources and Energy (2014c), "Strategic Energy Plan", Tokyo, available at: http://www.enecho.meti.go.jp/category/others/basic plan/pdf/140411.pdf.

Akbari, H. (2005), "Energy Saving Potentials and Air Quality Benefits of Urban Heat Island Mitigation", Ernest Orlando Lawrence Berkeley National Laboratory, http://www.osti.gov/scitech/servlets/purl/860475 (accessed 27 March 2015).

American Coalition for Clean Coal Electricity (2014), "Energy Cost Impacts on American Families, 2011-2014", available at: http://www.americaspower.org/sites/default/files/Trisko_2014.pdf.

ARUP and Rockefeller Foundation (2014), City Resilience Framework, Ove Arup \& Partners International Limited, London, UK.

Authenticated U.S. government information (2010), "U.S. Code § 17082 - Zero Net Energy Commercial Buildings Initiative", Authenticated U.S. government information, Washington DC, available at: http://www.gpo.gov/fdsys/pkg/USCODE-2010-title42/pdf/USCODE-2010-title42chap152-subchapIII-partB-sec17082.pdf.

Banister, D., P. Crist and S. Perkins (2015), "Land Transport and How to Unlock Investment in Support of "Green Growth", OECD Green Growth Papers, No. 2015/01, OECD Publishing, Paris, http://dx.doi.org/10.1787/5js65xnk52kc-en.

Barcelona City Council (2012), "Mesura de Govern: Programa d'Illes Autosuficients de Barcelona" (Government's measure: Programme of self-sufficiency for the city blocks in Barcelona), available at: $\underline{\text { http://governobert.bcn.cat/sites/default/files/MG_H\%C3\%A0bitat_Illes_190112.pdf. }}$

Barcelona City Council (n.d.a), "The Energy, Climate Change and Air Quality Plan of Barcelona (PECQ) 2011-2020", Barcelona City Council, Barcelona, available at: http://www.energycities.eu/db/Barcelona_SEAP_2011_en.pdf.

Barcelona City Council (n.d.b), Statistics website, http://www.bcn.cat/estadistica/angles/dades/index.htm (accessed September 2015).

Barcelona City Council (n.d.c), "Statistical Yearbook of Barcelona City website, Energy and Climate Change", http://www.bcn.cat/estadistica/angles/dades/anuari/index.htm (accessed September 2015).

Barcelona City Council (n.d.d), "Treball, Economia, i Planificació Estratègica" (Labour, Economy and Strategic Planning), http://ajuntament.barcelona.cat/treballieconomia/ca/ (accessed January 2016).

Barcelona City Council (n.d.e), "Pacte entre la Política i la Gestió - Marc Estratègi i Full de Ruta 2012-2015" (Politics-Management Pact - Strategic Framework and Roadmap 2012-2015), available at: http://governobert.bcn.cat/estrategiaifinances/sites/default/files/model estrategicca.pdf. 
Barcelona City Council (n.d.f), "Pla d'eficiència energètica en edificis municipals" (brochure), available at: http://governobert.bcn.cat/sites/default/files/docs/presentacio_eficiencia_energetica.pdf.

Barcelona City Council (n.d.g), "Energy, Mobility and Environmental Sectors in Barcelona", Barcelona City Council, Barcelona, available at: http://w42.bcn.cat/web/en/mediaroom/presentacions/index.jsp?componente=222-105399.

Barcelona City Council (n.d.h), "Ecología, Urbanismo y Movilidad - Azoteas Vivas y Cubiertas Verdes", http://ajuntament.barcelona.cat/ecologiaurbana/es/que-hacemos-y-porque/ciudadverde-y-biodiversidad/azoteas-vivas-y-cubiertas-verdes (accessed September 2015).

Barcelona City Council (n.d.i), "Ecología, Urbanismo y Movilidad - Compromiso Cuidadano por la Sostenibilidad - Barcelona+Sostenible", http://ajuntament.barcelona.cat/ecologiaurbana/es/quehacemos-y-porque/compromiso-ciudadano/compromiso-ciudadano-por-la-sostenibilidadbarcelona-sostenible (accessed September 2015).

Barcelona City Council (n.d.j), "Ecología, Urbanismo y Movilidad - Consejo Ciudadano de la Sostenibilidad", $\quad$ http://ajuntament.barcelona.cat/ecologiaurbana/es/que-hacemos-yporque/compromiso-ciudadano/consejo-ciudadano-de-la-sostenibilidad (accessed September 2015).

Barcelona City Council (n.d.k), "Supplying electricity guaranteed to come from renewable energy sources and from high-efficiency cogeneration", GPP 2020 Procurement for a low-carbon economy, Barcelona, Spain, available at: http://www.ajsosteniblebcn.cat/tenderelectricity 66649.pdf.

Barcelona City Council and Barcelona Energy Agency (2013), "Barcelona Energy Self-Sufficiency Plan" (brochure), (April), available at: http://www.energy-cities.eu/IMG/pdf/Barcelona-EnergyAgency_Irma-Soldevilla.pdf.

Bristol 2015 (2015a), "How to promote renewable energy generation", The Bristol Method, Bristol 2015, Bristol, (May), available at: https://www.bristol2015.co.uk/media/filer_public/d6/b7/d6b70312-0c1d-45f0-ba20354c6eac4636/how to promote renewable energy generation.pdf.

Bristol 2015 (2015b), Website, https://www.bristol2015.co.uk/ (accessed September 2015).

Bristol 2015 (2015c), "How to cut the carbon footprint of a city's building stock", The Bristol Method, Bristol 2015, Bristol, (January), available at: https://www.bristol2015.co.uk/media/filer_public/1f/cb/1fcb4a55-8c6d-4f15-a9ddb1b96d596a06/how_to_cut_the_carbon_footprint_of_a_citys_building_stock.pdf.

Bristol 2015 (2015d), "How to bring sustainability to life in the classroom", The Bristol Method, Bristol 2015, Bristol, (June), available at: https://www.bristol2015.co.uk/media/filer_public/f4/30/f430ab5c-f97a-43db-bd50e47dc8f94ee5/how to_bring_sustainability_to_life_in_the_classroom_v1_published_12615.pdf.

Bristol City Council (2015a), "HECA Further Report - March 2015" (brochure), available at: https://www.bristol.gov.uk/documents/20182/33423/15\%2002\%2025\%20BCC\%20HECA\%20 March\%202015\%20FINAL\%20Version\%20SIGNED.pdf/93d9fdd5-15d4-43d9-99dc5406b8fd0674 (accessed 19 January 2016).

Bristol City Council (2015b), "State of Bristol - Key Facts 2015", Bristol City Council, Bristol, available at: https://www.bristol.gov.uk/documents/20182/32947/State\%20of\%20the\%20City\%202013\%20Mayoral\%20vision\%20v8.pdf/cd19638b-9a4d-4b40-833f-c5866896db17. 
Bristol City Council (2014), "Environmental Statement", available at: http://ec.europa.eu/environment/emas/pdf/videoPage/ES_Bristol_City_Council.pdf.

Bristol City Council (2013a), "Bristol Health and Wellbeing Strategy", available at: https://www.bristol.gov.uk/documents/20182/34772/HW\%20Strategy\%20Document_2013_we b.pdf/9dcfd365-4f01-46be-aaf3-0874d75c7c33.

Bristol City Council (2013b), "The Energy Service", http://www.bristol.gov.uk/sites/default/files/documents/environment/environmental policy and _performance/energy_management/Energy_Service_Guide.pdf (accessed September 2015).

Bristol City Council (n.d.a), "Council Action on Climate Change", http://www.bristol.gov.uk/page/environment/council-action-climate-change\#jump-link-0 (accessed Sept 2015).

Bristol City Council (n.d.b), "The Energy Service", http://www.bristol.gov.uk/page/environment/energy-service (accessed Sept 2015).

Bristol City Council (n.d.c), "Council Use of Renewable Energy", http://www.bristol.gov.uk/page/environment/council-use-renewable-energy (accessed Septembre 2015).

Bristol City Council (n.d.d), "Bristol Climate Change and Energy Security Framework 2012-15", available at: $\quad$ http://carbonn.org/uploads/tx carbonndata/Strategy\%202012-15\%20\%20Climate\%20Change\%20and\%20Energy\%20Security\%20Framework.pdf.

Bristol Green Capital and The Bristol Partnership (2007), "Building a positive future for Bristol after peak oil", available at: http://transitionbristol.net/wp-content/uploads/2013/03/Peak-OilReport_01.pdf (accessed January 2016).

C40 Cities (2014), http://cityclimateleadershipawards.com/mayors-voices-munich-mayor-hepmonatzeder/ (accessed September 2015).

Cabinet office (2015), "The 2011 off the Pacific coast of Tohoku Earthquake (The Great East Japan Earthquake) in 2011", http://www.bousai.go.jp/2011daishinsai/pdf/torimatome20150909.pdf, (Accessed 3 March 2016).

Cabinet Office (2011a), "Estimates of the amount of damage by The Great East Japan Earthquakes", Tokyo, available at: http://www.bousai.go.jp/2011daishinsai/pdf/110624-1 kisya.pdf.

Cabinet office (2011b), "Efforts of Roppongi Hills", Tokyo, available at: https://www.kantei.go.jp/jp/singi/tiiki/toshisaisei/yuushikisya/anzenkakuho/231114/2.pdf.

Cabinet Secretariat (2014), "Fundamental Plan for National Resilience", Tokyo, available at: http://www.cas.go.jp/jp/seisaku/kokudo_kyoujinka/pdf/kk-honbun-h240603.pdf.

Chelleri, L. (2012), "From the 'Resilient City' to Urban Resilience: A review essay on understanding and integrating the resilience perspective for urban systems", Documents d'Anàlisi Geogràfica 2012, Vol. 58/2, Universitat Autònoma de Barcelona, Departament de Geografia, Barcelona, Spain, http://dag.revista.uab.es/article/view/v58-n2-chelleri (accessed March 2015).

City of Kyoto (2016a), "Kyoto energy-saving renovation of existing homes support project FY2015", City of Kyoto, Kyoto, available at: http://www.city.kyoto.lg.jp/tokei/page/0000181029.html. City $\begin{gathered}\text { Ko } \\ \text { http://www.city.kyoto.lg.jp/kankyo/page/0000163838.html (accessed } 18 \text { December 2015). }\end{gathered}$
(2016b), 
City of Kyoto (2015a), "Civic economic calculation", available at: http://www2.city.kyoto.lg.jp/sogo/toukei/Economy/Accounts/index.html $\quad$ (accessed 18 December 2015).

City of Kyoto (2015b), "GHG emissions in 2013", available at: http://www.city.kyoto.lg.jp/kankyo/page/0000186835.html (accessed 18 December 2015).

City of Kyoto (2015c), "Kyoto city statistics portal", City of Kyoto, Kyoto, available at: https://www2.city.kyoto.lg.jp/sogo/toukei/index.html (accessed 18 December 2015).

City of Kyoto (2015d), "Deployment of independent and decentralised energy system support project FY2015", http://www.city.kyoto.lg.jp/kankyo/page/0000164308.html (accessed 20 December 2015).

City of Kyoto (2015e), "List of the management entities and facilities of Kyoto Civic Co-operation Power Generation Scheme", available at: http://www.city.kyoto.lg.jp/kankyo/cmsfiles/contents/0000164/164195/table(1).pdf.

City of Kyoto (2015f), "Kyoto next generation energy system creation strategy", http://www.city.kyoto.lg.jp/sankan/page/0000177800.html (accessed 18 December 2015).

City of Kyoto (2015g), "Project on forming energy network among public facilities in Okazaki área", http://www.smartcity-kyoto-project.jp/theme01 (accessed 18 December 2015).

City of Kyoto (2014), "Urban Oilfield Development Project", http://www.city.kyoto.lg.jp/menu1/category/14-19-0-0-0-0-0-0-0-0.html (accessed 18 December 2015).

City of Kyoto (2013a), "Kyoto city strategy for promoting energy policy", available at: http://www.city.kyoto.lg.jp/kankyo/cmsfiles/contents/0000161/161721/senryaku_honbun.pdf.

City of Kyoto (2013b), "Information on Kyoto city strategy for promoting energy policy", http://www.city.kyoto.lg.jp/kankyo/page/0000161721.html (accessed 27 March 2015).

City of Kyoto (2013c), "Kyoto city Global Warming Countermeasures Ordinance", http://www.city.kyoto.lg.jp/kankyo/page/0000000209.html (accessed 18 December 2015).

City of Kyoto (2013d), "Installation standards for solar panels", http://www.city.kyoto.lg.jp/tokei/page/0000160119.html (accessed March 2015).

City of Kyoto (2013e), "Kyoto city master plan", http://www.city.kyoto.lg.jp/tokei/page/0000115733.html (accessed March 2015).

City of Kyoto (2013f), "Kyoto Civic Co-operation Power Generation Scheme", http://www.city.kyoto.lg.jp/kankyo/page/0000164195.html (accessed January 2016).

City of Kyoto (2011), "Flying into the future! Miyako Plan", http://www.city.kyoto.lg.jp/sogo/page/0000100989.html (accessed 18 January 2016).

City of Munich (2015a), "Entwicklung der EEG-Anlagen in München 2001-2014", Department of Health and Environment, City of Munich (June), available at: https://www.muenchen.de/rathaus/dms/Home/Stadtverwaltung/Referat-fuer-Gesundheit-und-

Umwelt/Dokumente/Klimaschutz und Energie/Regenerative Energie/web eeg anlagen muc 2014.pdf.

City Of Munich (2015b), "Munich : Future Perspective. Strategies, Guidelines, Projects", Perspective Munich, Department of Urban Planning and Building Regulation, City of Munich, (June).

City of Munich (2015c), "Bevölkerung”, http://www.muenchen.de/rathaus/Stadtinfos/Statistik/Bevlkerung.html (accessed December 2015). 
City of Munich (2014a), "CO2-Monitoring 1990-2012 of the Department of Health and Environment, City of Munich", available at: http://www.rismuenchen.de/RII/RII/DOK/SITZUNGSVORLAGE/3319421.pdf.

City of Munich (2014b), "Leitlinie Ökologie: Teil Klimawandel und Klimaschutz", City of Munich, Munich, available at: http://www.gemeinsam-fuer-das-klima.de/wpcontent/uploads/2014/02/20140205_Leitlinie-Oekologie_WEB.pdf.

City of Munich (2014c), "Munich Low Emission Zone", http://www.muenchen.de/rathaus/home_en/Environment-and-Health/Low_emission_zone (accessed September 2015).

City of Munich (2013) "Energiemanagement - Strom, Wärme, Wasser", available at: https://www.google.fr/url?sa=t\&rct=j\&q=\&esrc=s\&source=web\&cd=1\&cad=rja\&uact=8\&ved

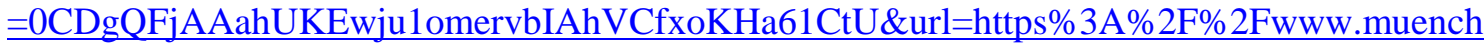
en.de\%2Frathaus\%2Fdms \%2FHome\%2FStadtverwaltung\%2FBaureferat\%2Fenergiemanageme nt\%2Fpdf\%2Fenergiemanagementbericht_2013.pdf\&usg=AFQjCNH6BR5mizLNuRiQtmLXY gJQd6ixrA.

City of Munich (2010), "International, Sustainable, United in Solidarity", available at: http://www.wirtschaft-muenchen.de/publikationen/pdfs/ins-en.pdf.

City of Munich (n.d.a), "Regenerative Energiequellen", http://www.muenchen.de/rathaus/Stadtverwaltung/Referat-fuer-Gesundheit-und-

Umwelt/Klimaschutz und Energie/Regenerative Energiequellen.html (accessed September 2015).

City of Munich (n.d.b), "Statistiches Amt", http://www.muenchen.de/rathaus/Stadtinfos/Statistik.html (accessed September 2015).

City of Munich (n.d.c), "Solarenergie", http://www.muenchen.de/rathaus/Stadtverwaltung/Referatfuer-Gesundheit-und-

Umwelt/Klimaschutz und Energie/Regenerative Energiequellen/Solarenergie.html (accessed September 2015).

City of Toronto (2016), "Council's Strategic Plan - City Directions", http://www1.toronto.ca/wps/portal/contentonly?vgnextoid=5f82bf1b19cb3410VgnVCM100000 71d60f89RCRD\&vgnextchannel=eabe8172dcfb3410VgnVCM10000071d60f89RCRD (accessed January 2016).

City of Toronto (2015a), "Economic Indicators - August 2015", available at: http://www1.toronto.ca/City\%20Of\%20Toronto/Economic\%20Development\%20\&\%20Culture/ Business\%20Pages/News,\%20Reports\%20\&\%20Resources/August\%202015\%20$\% 20$ current $\% 20$ issue.pdf.

City of Toronto (2015b), 2013 Greenhouse Gas Inventory, available at: http://www.toronto.ca/legdocs/mmis/2016/pe/bgrd/backgroundfile-87697.pdf.

City of Toronto (2015c), "Toronto Environmental Progress Report 2015", Toronto, Canada, available at: http://www.toronto.ca/legdocs/mmis/2016/pe/bgrd/backgroundfile-90610.pdf.

City of Toronto (2014a), "Energy Conservation and Demand Management Plan 2014-2019”, (July), available http://www1.toronto.ca/City\%200f\%20Toronto/Environment\%20and\%20Energy/Action\%20P1 ans, \%20Policies\%20\&\%20Research/PDFs/City\%20of\%20Toronto\%20ECDM\%20(20142019).pdf. 
City of Toronto (2014b) "Environment and Energy Division - 2014 Annual Report", available at: http://www1.toronto.ca/City\%20Of\%20Toronto/Environment\%20and\%20Energy/Divisional\%2 OProfile/A1501427 EED AnnualReport Aug11 WEB v3.pdf.

City of Toronto (2013), "Renewable Energy Policy for City Facilities" (brochure), available at: http://www1.toronto.ca/City\%20Of\%20Toronto/Environment\%20and\%20Energy/Greening\%20 City\%20Operations/PDFs/Renewable\%20Energy/RENEWABLE\%20ENERGY\%20POLICY\% 20FOR\%20CITY\%20FACILITIES_SEP2014.pdf.

City of Toronto (2012), "Backgrounder - 2011 Census: Population and Dwellings Counts", available at:

https://www1.toronto.ca/city of toronto/social development finance administration/files/pdf/ 2011-census-backgrounder.pdf.

City of Toronto (2009), "The Power to Live Green - Toronto's Sustainable Energy Strategy" (October), available at: http://www1.toronto.ca/city_of_toronto/environment_and_energy/key_priorities/files/pdf/200910_report.pdf.

City of Toronto (2007), "Climate Change, Clean Air and Sustainable Energy Action Plan: Moving from Framework to Action Phase 1 - Highlights", available at: http://www1.toronto.ca/City\%200f\%20Toronto/Environment\%20and\%20Energy/Programs\%2 0for\%20Residents/Files/pdf/C/clean air action plan.pdf.

City of Toronto (2002, revised 2015), "Toronto Official Plan", available at: http://www1.toronto.ca/planning/chapters1-5.pdf.

City of Toronto (n.d.a), "Economic Data Centre", http://www1.toronto.ca/wps/portal/contentonly?vgnextoid=e71032d0b6d1e310VgnVCM10000 071d60f89RCRD (accessed March 2016).

City of Toronto (n.d.b), "Community Energy Planning", http://www1.toronto.ca/wps/portal/contentonly?vgnextoid=4c096d820a926410VgnVCM10000 071d60f89RCRD (accessed September 2015).

City of Toronto (n.d.c), "Climate and Energy Goals", http://www1.toronto.ca/wps/portal/contentonly?vgnextoid=a201fbfa98491410VgnVCM100000 71d60f89RCRD (accessed September 2015).

City of Toronto (n.d.d), "Grants, Incentives \& Tips", http://www1.toronto.ca/wps/portal/contentonly?vgnextoid=821e99fa45dd5410VgnVCM100000 71d60f89RCRD (accessed September 2015).

City of Toronto (n.d.e), "Programs - District Energy System", http://www1.toronto.ca/wps/portal/contentonly?vgnextoid=81d86d820a926410VgnVCM10000 071d60f89RCRD (accessed September 2015).

Climate Alliance (2015), "Energy and $\mathrm{CO}_{2}$ monitoring", http://www.climatealliance.org/co2monitoring0.0.html (accessed January 2016).

Congress of the United States (2006), "The Economic Effects of Recent Increases in Energy Prices", Congress of the United States, Congressional Budget Office, Washington, DC. 20515, (July), available at: https://www.cbo.gov/sites/default/files/109th-congress-2005-2006/reports/07-21energy\%20dist.pdf.

CRED (2009), "EM-DAT Database", Brussels, http://www.emdat.be/database (accessed 3 December 2015). 
Department of Energy \& Climate Change, United Kingdom (2014), "Estimated impacts of energy and climate change policies on energy prices and bills", Crown copyright, Department of Energy \& Climate Change, London, United Kingdom, (November), available at: https://www.gov.uk/government/uploads/system/uploads/attachment_data/file/384404/Prices _ Bills report 2014.pdf.

Designated City Council on Renewable Energy (2011), "Prospectus of designated City Council on Renewable Energy", Designated City Council on Renewable Energy, available at: http://www.enekyo-city.jp/template/w/pdf/20110727_02.pdf.

EEFIG (Energy Efficiency Financial Institutions Group) (2015), "Energy Efficiency - the first fuel for the EU Economy. How to drive new finance for energy efficiency investments. Final Report covering Buildings, Industry, and SMEs", European Union, (February), available at: https://ec.europa.eu/energy/sites/ener/files/documents/Final\%20Report\%20EEFIG\%20v\%209.1 \%2024022015\%20clean\%20FINAL\%20sent.pdf.

EIA, US Department of Energy (n.d.), "Glossary", https://www.eia.gov/tools/glossary/index.cfm

ELCON (2004), “The Economic Impacts of the August 2003 Blackout”, Washington, DC, available at: http://www.elcon.org/Documents/Profiles\%20and\%20Publications/Economic\%20Impacts\%20o f\%20August \%202003\%20Blackout.pdf.

Energy Independence and Security Act of 2007, Pub. L. No 110-140, 121 Stat. 1492 (2007), Washington, DC, available at: http://www.gpo.gov/fdsys/pkg/PLAW-110publ140/pdf/PLAW110publ140.pdf.

Energy Service, Bristol City Council (2015), "Community Energy - Competition Public Briefing" (brochure), available at: https://www.bristol.gov.uk/documents/20182/33776/Community Energy Competition Brief May 2015_0.pdf/6e3e9466-2dfe-47ca-be40-a1f74594e2d3 (accessed September 2015).

Energy UK (n.d.), “The energy market explained”, available at: http://www.energy-uk.org.uk/energyindustry/the-energy-market.html.

The European Association of Local Authorities in Energy Transition (2013), "Empowering local and regional authorities to deliver the EU climate and energy objectives", EnergyCities, available at: http://www.energy-cities.eu/IMG/pdf/comm_2030_web.pdf.

European Commission (2016a), "2020 Energy Strategy”, http://ec.europa.eu/energy/en/topics/energystrategy/2020-energy-strategy (accessed January 2016).

European Commission (2016b), "2030 Energy Strategy”, http://ec.europa.eu/energy/en/topics/energystrategy/2030-energy-strategy (accessed January 2016).

European Commission (2016c), "2050 Energy Strategy”, http://ec.europa.eu/energy/en/topics/energystrategy/2050-energy-strategy (accessed January 2016).

European Commission "Co-operation mechanisms", http://ec.europa.au/energy/en/topics/renewable-energy/renewable-energy-directive/cooperationmechanisms (accessed September 2015).

European Commission (2015b), "Eurostat", European Commission, Luxembourg, http://appsso.eurostat.ec.europa.eu/nui/setupDownloads.do (accessed 16 December 2015).

European Commission (2014a), "Chapter 6: Energy Costs and EU Industrial Competitiveness", in European Competitiveness Report 2014, European Union, Luxembourg, http://ec.europa.eu/growth/industry/competitiveness/reports/eu-competitivenessreport/index_en.htm. 
European Commission (2014b), "Thematic glossaries", Brussels, http://ec.europa.eu/eurostat/statistics-explained/index.php/Thematic_glossaries (accessed December 2015).

European Commission (2007), "Blackout of November 2006: important lessons to be drawn", European Commission, Brussels, http://europa.eu/rapid/press-release_IP-07110_en.htm?locale=en (accessed 3 December 2015).

European Commission (n.d.), "Market legislation", Brussels, https://ec.europa.eu/energy/en/topics/markets-and-consumers/market-legislation (accessed December 2015).

European Parliament and Council of the European Union (2010), "Directive 2010/31/EU of the European Parliament and the Council of 19 May 2010 on the energy performance of buildings (recast) [2010] OJ L153/13", available at: http://eurlex.europa.eu/LexUriServ/LexUriServ.do?uri=OJ:L:2010:153:0013:0035:EN:PDF.

Ferguson, G. (n.d.), “A Vision for Bristol” (note), https://www.bristol.gov.uk/documents/20182/34880/vision-full-document-18-112013.pdf/485d6b4c-86e0-41e5-8f3e-70bdedfa5c46 (accessed December 2015).

Folke, C., S. Carpenter, T. Elmqvist, L. Gunderson, C.S. Holling, B. Walker (2002), "Resilience and Sustainable Development: Building Adaptive Capacity in a World of Transformations," Ambio, Vol. 31, No. 5, August 2002, Royal Swedish Academy of Sciences, Stockholm, Sweden, available at: http://www.era-mx.org/biblio/Resilience.pdf.

Freund, C. and C. Wallich (1995), "Raising Household Energy Prices in Poland. Who Gains? Who Loses?", Policy Research Working Paper 1495, The World Bank, (August), available at: http://documents.worldbank.org/curated/en/1995/08/697175/raising-household-energy-pricespoland-gains-loses (accessed March 2015).

Gillingham, K., R. Newell and K. Palmer (2009), "Energy Efficiency Economics and Policy”, NBER Working Paper Series, Working Paper 15031, National Bureau of Economic Research, Cambridge, England, (June), available at: http://www.nber.org/papers/w15031.pdf.

Hallegatte, S., C. Green, R.J. Nicholls and J. Corfee-Morlot (2013), "Future flood losses in major coastal cities", Nature Publishing Group, London, available at: http://www.nature.com/nclimate/journal/v3/n9/pdf/nclimate1979.pdf.

Hatziargyriou et al (2011), "CIGRE WG "Network of the Future" Electricity Supply Systems of the future", CIGRE, Paris.

Hines et al. (2009), "Trends in the History of Large Blackouts in the United States", IEEE, New York, available at: http://www.uvm.edu/ phines/publications/2008/Hines_2008_blackouts.pdf.

HM Government (2011), "Climate Resilient Infrastructure: Preparing for a Changing Climate", The Stationery Office Limited, UK, (May), available at: https://www.gov.uk/government/uploads/system/uploads/attachment_data/file/69269/climateresilient-infrastructure-full.pdf.

ICLEI (2014), "Carbon Cities Climate Registry", Bonn Center for Local Climate Action and Reporting (Carbonn Center) ICLEI - Local Governments for Sustainability, Bonn, available at: http://citiesclimateregistry.org/fileadmin/user upload/cCCR/cCCR 2014/cCCR-2013-annualreport.pdf.

IEA (2016), “Glossary”, https://www.iea.org/aboutus/glossary (accessed September 2015). 
IEA (2015a), "Energy Policy Review: Spain 2015”, OECD Publishing, Paris, http://dx.doi.org/10.1787/9789264239241-en.

IEA (2015b), "IEA/IRENA Joint Policies and Measures Database", http://www.iea.org/policiesandmeasures/renewableenergy/ (accessed September 2015).

IEA (2015c), "Promotion of Home Energy Management System (HEMS), Building Energy Management System (BEMS)", International Energy Agency, Paris, available at: http://www.iea.org/policiesandmeasures/pams/japan/name-22420-en.php.

IEA (2015d), "Energy and Climate Change", World Energy Outlook Special Report, OECD/IEA, Paris, France, available at: https://www.iea.org/publications/freepublications/publication/WEO2015SpecialReportonEnerg yandClimateChange.pdf.

IEA (2014a), “CO $\mathrm{O}_{2}$ Emissions from Fuel Combustion 2014”, International Energy Agency, Paris, http://dx.doi.org/10.1787/co2_fuel-2014-en.

IEA (2014b), "World Energy Investment Outlook", International Energy Agency, Paris, https://www.iea.org/publications/freepublications/publication/world-energy-investmentoutlook---special-report---.html (accessed September 2015).

IEA (2013), "Electricity Networks: Infrastructure and Operations", IEA, Paris, available at: https://www.iea.org/publications/insights/insightpublications/ElectricityNetworks2013 FINAL. pdf.

IEA (2009), "Cities, Towns and Renewable Energies: Yes, in my Front Yard”, OECD Publishing, Paris, http://dx.doi.org/10.1787/9789264076884-en.

IEA (2008), “World Energy Outlook 2008”, OECD Publishing, Paris, http://dx.doi.org/10.1787/weo2008-en.

INEA (Innovation and Networks Executive Agency) (2015), "CEF Energy", https://ec.europa.eu/inea/en/connecting-europe-facility/cef-energy (accessed 16 December 2015).

INSEE (n.d.a), "Commune de Perpignan", http://www.insee.fr/fr/themes/comparateur.asp?codgeo=COM-66136 (accessed 16 December 2015).

INSEE (n.d.b), "Populations légales 2013 - Perpignan" (Legal population data of 2013 - Perpignan), http://www.insee.fr/fr/ppp/bases-de-donnees/recensement/populationslegales/commune.asp?annee=2013\&depcom=66136, $($ accessed March 2016).

INSEE (n.d.c), "Commune de Perpignan - Dossier complet", http://www.insee.fr/fr/themes/dossier_complet.asp?codgeo=COM-66136 (accessed September 2015).

INSEE (n.d.d), "Chiffres clés Emploi-Population active" [Key figures - Employment and Active population],

http://www.insee.fr/fr/themes/tableau local.asp?ref id=EMP\&nivgeo=DEP\&codgeo=66\&mille $\underline{\text { sime }=2012}$ (accessed September 2015).

Institut dezentrale Energietechnologien (2014), "100ee-Regionen in Deutschland, Europa und der Welt" (100 RE Regions in Germany, Europe and the world), Institut dezentrale Energietechnologien GmbH, Kassel, Germany, available at: http://www.100ee.de/downloads/broschueren/?eID=dam_frontend_push\&docID=1396. 
Institute for Fiscal Studies (2013), "Household Energy Use in Britain: A Distributional Analysis", London, available at: http://www.ifs.org.uk/comms/r85.pdf.

Interagency Resilience Working Group (2012), "The Characteristics of Resilience Building: A discussion paper", PPA Resilience Learning Partnership Group, Bond Disaster Risk Reduction Group, Bond Development and Environment Group, available at: http://technicalconsortium.org/wp-content/uploads/2014/05/The-Characteristics-of-

Res_Building.pdf.

IPCC (2013), "IPCC, 2013: Climate Change 2013: The Physical Science Basis. Contribution of Working Group I to the Fifth Assessment Report of the Intergovernmental Panel on Climate Change [T.F. Stocker, D. Qin, G.-K. Plattner, M. Tignor, S.K. Allen, J. Boschung, A. Nauels, Y. Xia, V. Bex and P.M. Midgley (eds.)]" Cambridge University Press, Cambridge, United Kingdom and New York, NY, USA, 1535 pp, available at: https://www.ipcc.ch/report/ar5/wg1/.

IPCC (2007), "Climate Change 2007: The Physical Science Basis. Contribution of Working Group I to the Fourth Assessment Report of the Intergovernmental Panel on Climate Change [S. Solomon, D. Qin, M. Manning, Z. Chen, M. Marquis, K.B. Averyt, M. Tignor and H.L. Miller (eds.)]", Cambridge University Press, Cambridge, UK, and New York, http://www.ipcc.ch/publications_and_data/ar4/wg1/en/ch9s9-es.html (accessed 3 December 2015).

Japan Meteorological Agency (2015), "Knowledge on heat island effect", http://www.data.jma.go.jp/cpdinfo/himr faq/06/qa.html (accessed 3 December 2015).

Japanese Committee for Technical Investigation on Countermeasures for Earthquakes and Tsunamis Based on the Lessons Learned from the 2011 off the Pacific coast of Tohoku Earthquake (2011), "Data on damage", Cabinet Office, Tokyo, available at: http://www.bousai.go.jp/kaigirep/chousakai/tohokukyokun/1/pdf/sub2.pdf.

Jha, A.K., Todd W. Miner, and Zuzana Stanton-Geddes, eds. (2013), Building Urban Resilience: Principles, Tools, and Practice. Directions in Development. Washington, DC, World Bank. doi: 10.1596/978-0-8213-8865-5.

Kane, L. and Ault, G. (2014), A review and analysis of renewable energy curtailment schemes and Principles of Access: Transitioning towards business as usual", Energy Policy, Vol 72, pp. 6777 , (September), available http://www.sciencedirect.com/science/article/pii/S0301421514002213.

Kelly and Pollitt (2011), "The Local Dimension of Energy”, EPRG Working Paper 1103, Cambridge Working Paper in Economics 1114, (January), Cambridge, available at: http://www.econ.cam.ac.uk/dae/repec/cam/pdf/cwpe1114.pdf.

Kilian, L. (2007), "The Economic Effects of Energy Price Shocks", CEPR Discussion Paper $n^{\circ}$ DP6559, available at: http://www-personal.umich.edu/ lkilian/jel102807r1.pdf.

Klima - und Energie - Modellregionen (n.d.), "Klima- und Energie- Modellregionen", http://www.klimaundenergiemodellregionen.at/start.asp?ID=242159\&b=5126, (accessed 11 January 2016).

Kosmadakis (2013), "Renewable and Conventional Electricity Generation Systems: Technologies and Diversity of Energy Systems", Springer-Verlag London, London.

Lehtonen and Nyeb (2009), "History of electricity network control and distributed generation in the UK and Western Denmark", Elsevier B.V., Amsterdam, available at: http://www.sciencedirect.com/science/article/pii/S030142150900072X. 
Ligue ENR (2013), "Perpignan Méditerranée Is About to Meet All Its Residential Electricity Needs With Renewable Energy", http://www.ligue-enr.fr/eng/best-practices/perpignan-mediterraneeis-about-to-meet-all-its-residential-electricity-needs-with-renewable-energy September 2015).

Lopez A. et al. (2012), "U.S. Renewable Energy Technical Potentials: A GIS-Based Analysis", National Renewable Energy Laboratory, Colorado, available at: http://www.nrel.gov/docs/fy12osti/51946.pdf.

Maréchal, K. (2009), "An Evolutionary Perspective on the Economics of Energy Consumption: The Crucial Role of Habits", Journal of Economic Issues, Vol. 43:1, pp. 69-88, (March), available at: http://www.tandfonline.com/doi/pdf/10.2753/JEI0021-3624430104.

METI (Ministry of Economy, Trade and Industry), Japan (2013), "FY2012 Annual Report on Energy", Tokyo, available at: http://www.enecho.meti.go.jp/about/whitepaper/2012pdf/.

METI (Ministry of Economy, Trade and Industry), Japan (2012), "FY2011 Annual Report on Energy", Tokyo, available at: http://www.enecho.meti.go.jp/about/whitepaper/2011pdf/whitepaper2011pdf_1.pdf.

METI (Ministry of Economy, Trade and Industry), Japan (2011), "Implementation of rolling http://www.meti.go.jp/earthquake/electricity supply/0325 electricity supply $0101 . p d f$.

METI (Ministry of Economy, Trade and Industry), Japan (2010), "FY2009 Annual Report on Energy", Tokyo, available at: http://www.enecho.meti.go.jp/about/whitepaper/2009pdf/.

METI (Ministry of Economy, Trade and Industry), Japan (2009), "Realisation and development of ZEB“, Ministry of Economy, Trade and Industry, Tokyo, available at: http://www.meti.go.jp/report/downloadfiles/g91124d01j.pdf.

Ministry of Development, Spain (2014), "Long-Term Strategy for Energy Renovation in the Building Sector in Spain Pursuant to Art.4 of Directive 2012/27/EU", (June), available at: http://www.fomento.gob.es/NR/rdonlyres/772D26EF-6906-4AD9-9253775615069E34/130070/ESArt4ENENER2014010090000ENTRA00.pdf.

Ministry of Ecology, Sustainable Development and Energy, France (2015), "Stratégie Nationale de Transition Ecologique vers un Développement Durable 2015-2020" (National Strategy of Ecological Transition Towards Sustainable Development 2015-2020), Paris, available at: http://www.developpement-durable.gouv.fr/IMG/pdf/SNTEDD.pdf.

Ministry of Ecology, Sustainable Development and Energy, France (n.d.), "La transition énergétique pour la croissance verte" (Energy transition for green growth) (brochure), available at: http://www.developpementdurable.gouv.fr/IMG/pdf/LANGUEDOC ROUSSILLON Perpignan.pdf.

Ministry of Economy and Energy, Germany (2014), "Central Projects for the Energy Transition - 10points Energy Agenda of the Ministry of Economy and Energy" (brochure), Berlin, available at: http://www.bmwi.de/BMWi/Redaktion/PDF/0-9/10-punkte-energieagenda, property $=$ pdf, bereich $=$ bmwi2012, sprache $=$ de, $r w b=$ true. $p d f$.

Ministry of Energy, Ontario (Canada) (2015), "The End of Coal", http://www.energy.gov.on.ca/en/archive/the-end-of-coal/, (accessed March 2016).

Ministry of Finance, Ontario (2010), “Ontario Population Projections Update, 2009-2036”, Toronto, Ontario, $\quad$ available

at: http://www.fin.gov.on.ca/en/economy/demographics/projections/projections2009-2036.pdf. 
Ministry of Land, Infrastructure, Transport and Tourism, Japan (2012), "Transportation Statistics" Tokyo, http://www.mlit.go.jp/statistics/kotsusiryo.html (accessed 18 December 2015).

Miyako Anshin Sumai Centre (n.d.), "Miyako Anshin Sumai Centre", Miyako Anshin Sumai Centre, Kyoto, available at: http://www.kyoto-jkosha.or.jp/sumai/index.html.

MOE (Ministry of the Environment), Japan (2014), "Requirements for solar panels by local governments", Tokyo, available http://www.env.go.jp/nature/mega solar na/conf/h2601/mat05 1.pdf.

MOE (Ministry of the Environment), Japan (2010), "Research on environmental impacts by heat island effect", Tokyo, http://www.env.go.jp/air/report/h22-05/index.html (accessed 3 December 2015).

MOE (Ministry of the Environment), Japan (2007), "Guideline for developing regional promotion plans for combating global warming”, Tokyo, http://www.env.go.jp/air/report/h2205/index.html (accessed 7 January 2016).

Natural Resources Canada and US Department of Energy (2006), "Final Report on the Implementation of the Task Force Recommendations", Washington, DC, available at: http://energy.gov/sites/prod/files/oeprod/DocumentsandMedia/BlackoutFinalImplementationRe port $\% 282 \% 29$.pdf.

Nottingham City Council (2010), "Energy Strategy 2010-2020”, Nottingham, UK, http://www.nottinghamcity.gov.uk/CHttpHandler.ashx?id=19119\&p=0 (accessed September 2015).

OECD (2015a), "Resilient Cities, Framework for Resilient Cities", Paris, http://www.oecd.org/gov/regional-policy/resilient-cities.htm (accessed June 2016).

OECD (2015b), "The Metropolitan Century: Understanding Urbanisation and its Consequences", OECD Publishing, Paris, http://dx.doi.org/10.1787/9789264228733-en.

OECD (2015c), "Energy Balances of OECD Countries 2015”, OECD Publishing, Paris, http://dx.doi.org/10.1787/energy_bal_oecd-2015-en.

OECD (2015d), "Energy Prices and Taxes, Vol. 2015/3", OECD Publishing, Paris, http://www.oecdilibrary.org/energy/energy-prices-and-taxes/volume-2015/issue-3_energy_tax-v2015-3-en.

OECD (2015e), “OECD.Stat”, OECD, Paris, http://stats.oecd.org/ (accessed 3 December 2015).

OECD (2015f), “Aligning Policies for a Low-carbon Economy", OECD Publishing, Paris, available at: http://dx.doi.org/10.1787/9789264233294-en.

OECD (2015g), "Mapping Channels to Mobilise Institutional Investment in Sustainable Energy", Green Finance and Investment, OECD Publishing, Paris, http://dx.doi.org/10.1787/9789264224582-en.

OECD (2015h), "Policy Guidance for Investment in Clean Energy Infrastructure: Expanding Access to Clean Energy for Green Growth and Development", OECD Publishing, Paris, http://dx.doi.org/10.1787/9789264212664-en.

OECD (2015i), "National Policy Frameworks on Resilience and Cities", Paris, available at: http://www.oecd.org/gov/regional-policy/national-policy-resilience-frameworks.pdf.

OECD (2014a), "Resilient Economies and Inclusive Societies - Empowering People for Jobs and Growth - 2014 Ministerial Council Statement", http://www.oecd.org/mcm/2014-ministerialcouncil-statement.htm, (accessed February 2016). 
OECD (2014b), "Issue Note - Addressing Social Implications of Green Growth, Session 1 Energy Sector Reform and Its Impacts on Households", Green Growth and Sustainable Development Forum, OECD Publishing, Paris, available at: http://www.oecd.org/greengrowth/Issue\%20Note\%20Session\%20One\%20GGSD\%20Forum.pd f.

OECD (2013), "Green Growth in Cities, OECD Green Growth Studies", OECD Publishing, Paris, http://dx.doi.org/10.1787/9789264195325-en.

OECD (2012a), "Linking Renewable Energy to Rural Development, OECD Green Growth Studies", OECD Publishing, Paris, http://dx.doi.org/10.1787/9789264180444-en.

OECD (2012b), "Redefining "Urban": A New Way to Measure Metropolitan Areas", OECD Publishing, Paris, http://dx.doi.org/10.1787/9789264174108-en.

OECD (2012c), "The OECD Metropolitan Areas Database", OECD Publishing, Paris, http://measuringurban.oecd.org/\#story=0 (accessed 3 December 2015).

OECD (2012d), "OECD Environmental Outlook to 2050", OECD Publishing, Paris, http://dx.doi.org/10.1787/888932570468 (accessed 3 December 2015).

OECD (2011), "Energy security", in OECD, Better Policies for Development: Recommendations for Policy Coherence, OECD Publishing, Paris, http://dx.doi.org/10.1787/9789264115958-16-en.

OECD (2010), "Policy Roundtables - Electricity: Renewables and Smart Grids" (note), available at: http://www.oecd.org/regreform/sectors/46586020.pdf.

OECD (2008), "Competitive Cities and Climate Change", OECD Conference Proceedings, Milan, page 142, available at: https://www1.oecd.org/gov/regional-policy/50594939.pdf.

OECD (2007), "OECD Contribution to the United Nations Commission on Sustainable Development 15 Energy for Sustainable Development", OECD Publishing, Paris, available at: http://www.oecd.org/greengrowth/38509686.pdf.

OECD (n.d.a), "Linking Renewable Energy to Rural Development. Executive Summary. Brief for Policy Makers", OECD, Paris, available at: http://www.oecd.org/regional/regionalpolicy/Renewable-rural-energy-summary.pdf.

OECD (n.d.b), "Glossary of statistical terms", OECD, Paris, https://stats.oecd.org/glossary/ (accessed January 2016).

Office for National Statistics, UK (2012), "2011 Census, Population and Household Estimates for England and Wales", Newport, UK, http://www.ons.gov.uk/ons/publications/re-referencetables.html?edition=tcm\%3A77-257414 (accessed 27 March 2015).

Ontario Financing Authority (2016), "Province of Ontario Green Bonds", http://www.ofina.on.ca/greenbonds/greenbonds.htm (accessed March 2016).

Perpignan City Council (2015), "Rapport 2014 sur la situation en matière de développement durable à la ville de Perpignan" (Report on the situation regarding sustainable development in Perpignan City), City of Perpignan, Perpignan, http://www.mairie-perpignan.fr/fr/cadre-vie/plan-climatgrenelle/les-rapports-la-situation-en-matiere-developpement-durable (accessed March 2015).

Perpignan City Council (2014), "Contrat de Ville de Perpignan Méditerranée - Contrat Cadre", december, http://www.mairie-perpignan.fr/fr (accessed March 2015).

Perpignan City Council (2012), "Présentation du Plan Climat Energie Territorial", http://www.mairie-perpignan.fr/fr/cadre-vie/presentation-plan-climat-energie-territorial-pcet (accessed September 2015). 
Perpignan City Council (n.d.), "Principaux éléments à retenir des diagnostics de 2012" (Main elements to remember about 2012 diagnoses), http://www.mairie-perpignan.fr/fr/cadre-vie/planclimat-grenelle/bilan-emissions-gaz-effet-serre/principaux-elements-retenir, (accessed March 2016).

Perpignan Méditerranée (2016), "Bilan Carbone, Le Diagnostic Local" (Carbon assessing, the local diagnosis), Délégation Générale au Développement Durable - Communauté Urbaine Perpignan Méditerranée, France, available at: http://www.perpignanmediterranee.com/fichiers_agglo/documents/DDbilancarbone2014comple t.pdf.

Perpignan Méditerranée (2015), "L'Agglo sur le terrain de l'Ecoparc Catalan", http://www.perpignanmediterranee.com/L\%E2\%80\%99Agglo-sur-le-terrain-de1\%E2\%80\%99Ecoparc-Catalan--6135.phtm (accessed April 2015).

Perpignan Méditerranée (2012), "Plan Climat-Énergie Territorial de PMCA et de Perpignan 20122017' (Territorial Climate-Energy Plan of PMCA and Perpignan 2012-2017), (September), available at: http://agenda21-perpignanmediterranee.com/wp-content/uploads/plan-climatperpignan-pmca.pdf.

Perpignan Méditerranée (n.d.a), «La Communauté urbaine c'est quoi ?» (What is the Communauté Urbaine ?), http://www.perpignanmediterranee.com/L-agglo-c-est-quoi--5145.phtm, (accessed March 2016).

Perpignan Mediterranée (n.d.b), "Ecoparc Catalan”, http://www.perpignanmediterraneeenr.com/index.php?p=ecoparc (accessed September 2015).

Pollitt (2012), "Lessons from the history of independent system operators in the energy sector", Elsevier B.V., Amsterdam, available at: http://www.sciencedirect.com/science/article/pii/S0301421512002923.

Rae and Bradley (2012), "Energy autonomy in sustainable communities - A review of key issues", Renewable and Sustainable Energy Reviews, Vol. 16, pp. 6497-6506, (December), available at: http://www.sciencedirect.com/science/article/pii/S1364032112004716.

Referat für Gesundheit und Umwelt (2014), "CO2-Monitoring 1990 - 2012", available at: http://www.ris-muenchen.de/RII/RII/DOK/SITZUNGSVORLAGE/3319421.pdf.

Renewable Energy Foundation (2014), "DECC Publishes Energy Price Impacts", http://www.ref.org.uk/ref-blog/325-decc-publishes-energy-price-impacts, (accessed March 2016).

Ruttera and Keirsteadb (2012), "A brief history and the possible future of urban energy systems", Elsevier B.V., Amsterdam, available at: http://www.sciencedirect.com/science/article/pii/S0301421512002777.

Sakai City (2011), "Energy supply and demand of Sakai City in 2011", Sakai, available at: http://www.city.sakai.lg.jp/shisei/gyosei/shishin/kankyo/ondanka/energy_policy.files/followup2011.pdf.

Salix Finance (2015), http://www.salixfinance.co.uk/, London, (accessed September 2015).

Schock and Sims (2012), "Energy Supply Systems", in Global Energy Assessment - Toward a Sustainable Future, Cambridge University Press, Cambridge, UK and New York, NY, USA, and the International Institute for Applied Systems Analysis, Laxenburg, Austria, available at: http://www.iiasa.ac.at/web/home/research/Flagship-Projects/Global-Energy-

Assessment/GEA Chapter15 supply lowres.pdf. 
Sexton, S., Wu, J. and Zilberman, D. (2012), "How High Gas Prices Triggered the Housing Crisis: Theory and Empirical Evidence", Selected Works of Steven E. Sexton, University of California, Berkeley, (January), available at: http://citeseerx.ist.psu.edu/viewdoc/summary?doi=10.1.1.373.1977.

Stadwerke München (2016), https://www.swm.de/english.html (accessed May 2016).

Statistics Bureau of Japan (2011), "Population census 2010", Tokyo, http://www.stat.go.jp/data/kokusei/2010/ (accessed 27 March 2015).

Su and Wang (2012), "Energy Management Systems in Microgrid Operations", The Electricity Journal, Vol. 25-8, pp. 45-60, (October), available at: http://www.sciencedirect.com/science/article/pii/S104061901200214X.

Suisse Energie (2015), "Portraits de projets des Régions-Energie - Recueil d'exemples de projets communaux et intercommunaux", http://www.regionenergie.ch/fileadmin/user_upload/Energieregion/fr/Dateien/Portraits_de_projets/EnergieRegion_Projektportraits_Gesamtdokument_FR.pdf.

SWM (2016a), "SWM's Green Energy Plants - Munich and Region, Germany and Europe", available at: $\quad$ https://www.swm.de/dam/jcr:6b51fbab-df16-493b-92e4-5c4385e50dfd/map-renewableenergies.pdf.

SWM (2016b), https://www.swm.de/english.html (accessed May 2016).

SWM (2015a), "SMW Renewable Energies Expansion Campaign", http://www.swm.de/english/company/energy-generation/renewable-energies.html, Stadtwerke München GmbH, Munich (accessed September 2015).

SWM (2015b), "Vision: District heating from regenerative energy sources", https://www.swm.de/english/m-fernwaerme/vision-district-heating.html, Stadtwerke München GmbH, Munich (accessed September 2015).

SWM (n.d.), "Press Information - SWM Renewable Energies Expansion Campaign" (brochure), Stadwerke München $\mathrm{GmbH}, \quad$ Munich, available at: http://www.swm.de/dms/swm/dokumente/english/projects-renewable-energies-expansioncampaign.pdf.

Tokyo Metropolitan Government (2014), "Measures against climate change", http://www.kankyo.metro.tokyo.jp/climate/other/countermeasure/phenomenon/index.html (accessed 3 December 2015).

UCTE (2007), "Final Report System Disturbance on 4 November 2006", Union for the Co-ordination of Transmission of Electricity, Brussels, available at: https://www.entsoe.eu/fileadmin/user_upload/_library/publications/ce/otherreports/FinalReport-20070130.pdf.

UNFCCC (2015a), "Historic Paris Agreement on Climate Change", http://newsroom.unfccc.int/unfccc-newsroom/finale-cop21/ (accessed January 2016).

UNFCCC (2015b), "Cities \& Regions Launch Major Five-Year Vision to Take Action on Climate Change", http://newsroom.unfccc.int/lpaa/cities-subnationals/lpaa-focus-cities-regions-acrossthe-world-unite-to-launch-major-five-year-vision-to-take-action-on-climate-change/ (accessed January 2016).

Union of Kansai Governments (2014), "Kansai Energy Plan”, Union of Kansai Governments, Osaka, Japan, available at: http://www.kouiki-kansai.jp/data_upload/1393226279.pdf. 
United Nations (2014), "World Urbanization Prospects: The 2014 Revision", New York, http://esa.un.org/unpd/wup/CD-ROM (accessed 3 December 2015).

United Nations (2011), "Sustainable Energy for all", available at: http://www.se4all.org/sites/default/files///2014/02/SG_Sustainable_Energy_for_All_vision.pdf.

US Department of Energy (2010), "Statement of Secretary Steven Chu U.S. Department of Energy Before the Senate Committee on Energy and Natural Resources FY 2011 Budget Hearing February 4, 2010", Washington DC, available at: http://energy.gov/sites/prod/files/ciprod/documents/2-4-10_Final_Testimony_(Chu).pdf.

US Department of Energy (2012), "Hurricane Sandy Situation Report \# 5", Washington DC, available at: http://www.oe.netl.doe.gov/docs/2012 SitRep5 Sandy 10302012 300PM v 1.pdf.

US Department of Energy (n.d.), "Distributed Energy", Washington, DC, http://energy.gov/oe/technology-development/smart-grid/distributed-energy (accessed September 2015).

US Environmental Protection Agency (2008), "Reducing Urban Heat Islands: Compendium of Strategies", US Environmental Protection Agency, Washington DC, available at: http://www.epa.gov/sites/production/files/2014-06/documents/basicscompendium.pdf.

US Environmental Protection Agency (n.d.), "Human Health and Environmental Effects of Emissions from Power Generation" (brochure), US Environmental Protection Agency, Washington DC, available at: http://www3.epa.gov/captrade/documents/power.pdf.

US Executive Office of the President (2011), "A Policy Framework for the $21^{\text {st }}$ Century Grid: Enabling Our Secure Energy Future", available at: https://www.whitehouse.gov/sites/default/files/microsites/ostp/nstc-smart-grid-june2011.pdf.

US.-Canada Power System Outage Task Force (2004), "Final Report on the August 14, 2003 Blackout in the United States and Canada: Causes and Recommendation", U.S.-Canada Power System Outage Task Force, Washington DC, available at: http://energy.gov/sites/prod/files/oeprod/DocumentsandMedia/BlackoutFinal-Web.pdf.

The World Bank Treasury (2009), "World Bank Green Bonds - What is a green bond and how does it differs from a regular bond?", http://treasury.worldbank.org/cmd/htm/Chapter-2-UnderstandingGreen-Bonds.html, (accessed March 2016). 